\title{
Development Traceability Systems for Agricultural products in India
}

By: Keshav Prakash Dandage

$\mathrm{PhD}$ Thesis

\section{Universidad Politécnica de Madrid}

Escuela Técnica Superior De Ingeniería Agronómica, Alimentaria Y De Biosistemas 
Development Traceability Systems for Agricultural products in India

\author{
Doctorando: Keshav Prakash Dandage \\ Director: Luis Ruiz García (Doctor Ingeniero Agrónomo)
}

Madrid 2018 



\section{Acknowledgement}

I would like to express my sincere gratitude to my guide Professor Luis Ruiz García, who offered me guidance and support all along the development of the study. He encouraged me to investigate various avenues and let me learnt many things by myself, which made this whole experience notably enriching for me as well as his pain-staking effort in proof reading the drafts, are greatly appreciated. Indeed, without his guidance, I would not be able to put the topic together.

Also express my sincere thanks to Commissionrate of Social Welfare, Pune, Maharashtra State (India) those who granted me scholarship for completing my higher education.

It is my privilege to thank to Dr. Sumita Kanojia, from the Department of Civics and Politics, University of Mumbai, India, for relentless support that made possible work in situations that I would not have dreamed possible.

To Dr. Ricardo Badía Melis, from the Department of Escuela Técnica Superior de Ingeniería Agronómica, Alimentaria y de Biosistemas, Universidad Politécnica de Madrid, for providing me necessary suggestions and helping me out during my research pursuit.

I am really thankful to those authors past and present whose contribution were of great help to undertaken these investigations.

I sincerely acknowledge the moral support which received from my beloved parents, brother Ravi and Pravin and my almighty lord Vitthala and Lord Buddha.

Again, one more time I would like to express my sincere thanks to Universidad Politécnica de Madrid, Spain for providing me an opportunity to undertake the $\mathrm{PhD}$ study in this university. 


\section{Contents}

\section{Pages}

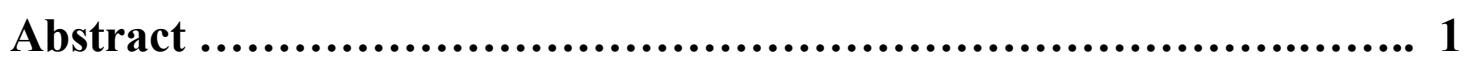

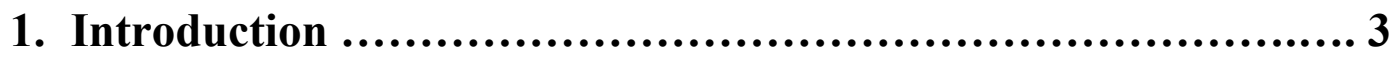

2. Problem Statement.............................................11

2.1 Lack of food traceability control systems in India............................11

2.2 Organization of the Indian food sector....................................... 13

2.3 Adoption of ICT tools in Indian farmer group...............................14

3. State of the Art................................................16

3.1 Necessity of traceability in the Indian food Industry..........................16

3.2 Effective traceability techniques in India................................... 19

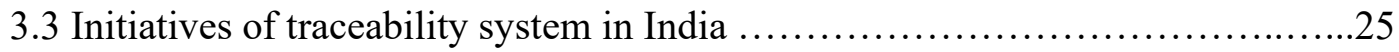

3.4 Estimate cost for food traceability in India................................28

$$
\text { i I P a g e }
$$


5.1 ICT Adoption in Small Holders Banana Farmers and Traders in India: A Case Study on Jalgaon District.

5.1.1 Introduction.

5.1.2 Material and Methods.

5.1.3 Results and discussions.

5.1.4 Conclusions about ICT adoption in Small Holders Banana Farmers and Traders

5.2 Food Traceability Through Web and Smart Phone for Farmers Agriculture Products in India: Cloud Services and Web APIs

5.2.1 Introduction.

5.2.2 Materials and Methods. .78

5.2.3 Results

5.2.4 Conclusions about food traceability through web and smart phone .88

5.2.5 Limitations .89

6. Discussions 
7. Final Conclusions

References. 


\section{Tables}

Table 1.1: Latest digital technology Initiatives for Indian Agriculture sector.................7

Table 3.1: Emerging solutions by private and government sector in India..................24

Table 3.2: Estimated cost for Indian traceability system................................29

Table 5.1: Farming profile in India and distribution of holdings.......................41

Table 5.2: Percentage for ICT Adoption in smallholding banana farmers...................51

Table 5.3: Percentage for ICT Adoption in Banana Traders................................52

Table 5.4: Constraint influencing factors for banana farmers...........................54

Table 5.5: Garrett's percent Position and Garrett's Score..............................54

Table 5.6: Calculated Garrett Score.................................................55

Table 5.7: Adoption of ICT tools for Farmers....................................... 57

Table 5.8: Adoption of ICT tools for Traders........................................58

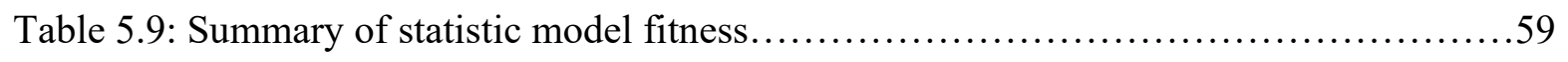

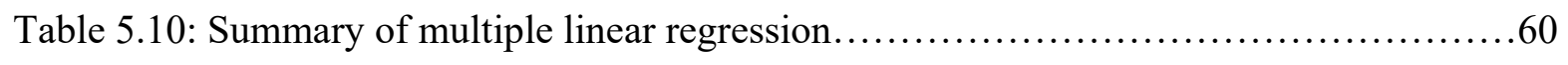

Table 5.11: Pearson's r Correlations box..........................................62

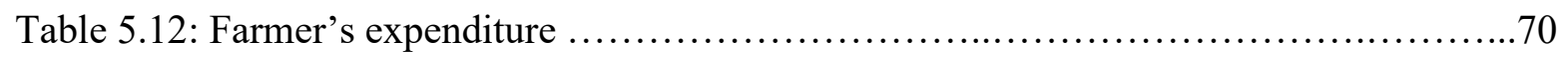

$$
\text { iv I P a g e }
$$




\section{Figures}

Figure 3.1: Traceability Implementation Model .........................................26

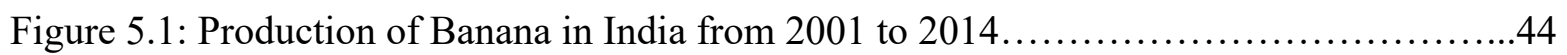

Figure 5.2: Tehsil of Jalgaon District....................................................

Figure 5.3: Graphical Representation of Global Banana Production vs. Jalgaon District,

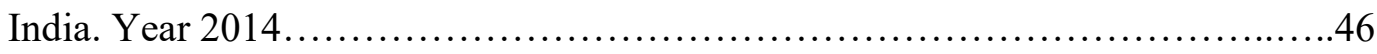

Figure 5.4: Constraint Influencing Factors in adopting ICT ..............................56

Figure 5.5: Farmer trading gateway through Direct and Stepwise process in India...............72

Figure 5.6: Sequence Architecture of an entire Application................................78

Figure 5.7: Architecture of an entire Application of farmer production traceability system......80

Figure 5.8: Home Page of the application......................................... 82

Figure 5.9: Indoor Facilities presented after registering by User........................83

Figure 5.10: Using drop down menu and filtering the database with Checkbox options...........84

Figure 5.11: List of farmers presented on table with Farmer ID, Province, and Horticulture crop..................................................... 85

Figure 5.12: Providing security for farmer's data using One Time Password (Authentication Page) .86

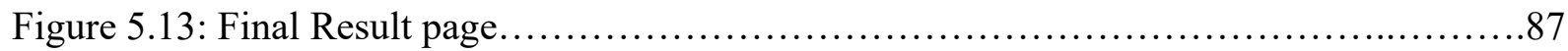



Abbreviations List
AGMARK Agriculture Marketing
APEDA Agricultural \& Processed Food Products Export Development Authority
API Application Programme Interfaces
APMC Agricultural Produce Market Committee
AS
Average Score
ASPA
Authentication Solution Providers' Association
ASSOCHAM Associated chambers of commerce and Industry of India
AWS
Amazon Web Services
B2B
Business to Business
B2G
Business to Government
BIS
Bureau of Indian Standards
CAGR
Compound Annual Growth Rate
CEO
Chief Executive Officer
CHAMAN Coordinated Horticulture Assessment and Management using Geoiformatics
CII Confederation of Indian Industry
CRM Customer Relationship Management 
CSO Central Statistics Office

DoT Department of Telecommunication

ERP Enterprise Resource Planning

FAO Food and Agricultural Organization

FASAL Forecasting Agricultural Output using Space, Agrometeorology \& Land

FDI Foreign Direct Investment

FDA Food and Drug Administration

FICCI Federation of Indian Chambers of Commerce and Industry

FoSCoRIS $\quad$ Food Safety Compliance Through Regular Inspections and Sampling

FoLNet Food Laboratory Network

FPO Food Products Order

FPTS Farmer Production Traceability System

FSANZ Food Standards Australia New Zealand

FSMA Food Safety Modernization Act

FSS Food Safety and Standards Act

FSSAI Food Safety and Standards Authority of India

GCP Global Company Prefix

GDP Gross Domestic Product

GFTC Global Food Traceability Centre 
GHP Good Hygiene Practices

GI Geographical Indication

GIS Geographic Information System

GLN Global Location Numbers

GPS Global Positioning System

GS1 Global Standards One

GTIN Global Trade Item Numbers

GUI Graphics User Interface

Ha Hectare

HACCP Hazard Analysis and Critical Control Points

HTTP Hypertext Transfer Protocol

HTTPS Hypertext Transfer Protocol Secure

HTML Hypertext Markup Language

IBEF India Brand Equity Foundation

IBM International Business Machine Corporation

IIP Indian Institute of packaging

ICT Information and Communication Technology

IFFCO Indian Farmers Fertiliser Cooperative Limited

IKSL

IFFCO Kisan Sanchar Limited 
IAMAI Internet and Mobile Association of India

IMC Indian Merchants Chambers

IoT Internet of Thing

ISAP Indian Society of Agribusiness Professionals

ISRO Indian Space Research Organization

ISO International Organization for Standardization

ITC India Tobacco Company

IT Information Technology

IVR Interactive Voice response

KISAN Krop Insurance using Space Technology and Geoiformatics

vKVK Virtual Krishi Vigyan Kendra

LEAF Lawrencedale Agro Processing India

M Mean

MMS Multimedia Messaging Service

NABARD National Bank for Agriculture and Rural Development

NADAMS National Agricultural Drought Assessment \& Monitoring System

NHB National Horticulture Board

NHRDF National Horticulture Research and Development Foundation

NOFN National Optical Fibre Network

$$
\text { ix | P a g e }
$$


NPD New Product Development

NSS National Sample Survey

PAAS Platform as a Service

PEIB UPC Produce Electronic Identification Board Universal Product Codes

PEIB PLU Produce Electronic Identification Board Price Look Up Codes

PMA Produce Marketing Association

QCIN Quality Council of India

QR Quick Response

REST Representational State Transfer

RFA Rain Forest Alliance

R\&D Research and Development

RFID Radio Frequency Identification

SAP System, Application, Products

SD Standard Deviation

SMEs Small Medium-sized Enterprises

SMS Short Message Service

SKU Stock Keeping Unit

SOAP Simple Object Access Protocol

SPS Sanitary and PhytoSanitary 
PhD Thesis

Keshav Prakash Dandage

Abbreviations list

SPSS Statistical Package for the Social Science

TCS Tata consultancy services

UI User Interface

URL Uniform Resource Locator

USA United States of America

USD United States Dollar

UIDAI Unique Identification Authority of India

VIF Variance Inflation Factor

WHO World Health Organization

XML Extensible Markup Language 
xii I P a g e 


\section{Abstract}

Food safety has become a major concern in India, after the adulterated milk scam, usage of toxic chemicals in food and change the essential ingredient with something lesser value were found on large extent in recent years. Thus, there is a need of proper traceability systems in the Indian food industry, for reducing the cases of food safety incidents and fraudulence. With purpose in mind, in the beginning of this $\mathrm{PhD}$ thesis, there is a review of the existing traceability techniques in India which include RFID, Holograms, Barcode and other tracking media to monitor production processes. There are some Indian initiatives of food traceability system from APEDA in association with GS, that have created Anarnet, Peanut.net, Meat.net and Grapenet that control traceability for certain products. Also, there are some experiences with barcoding and several ICTs initiatives that are actively working in many states of India, that try to control the food safety and protect the consumers.

However, several problems are extensively affecting the Indian food sectors that unbalanced their routine activities. The current traceability systems are behaving abnormally due to number of factors like the high level of illiteracy and lack of proper infrastructures. These situations block the implementation and adoption of ICT initiatives in rural India.

In this framework, the objectives of the thesis are: 1) To evaluate current food traceability systems in India and assess the level of ICT adoption in rural India; 2) To analyze the 
shortcomings of ICT initiatives amongst the smallholders' farmers in India 3) To support local food systems in India and direct sourcing of raw material from farmers to customer, retailer, food business operator, and exporter in India. 4) To increase the net income of smallholder farmers by providing market facility at the farm gate through web-based traceability portal in India.

For achieving these objectives, two experimental studies were done. The first one (section 5.1), was focused in the adoption of ICT tools for tracking and tracing banana batches, in a case study in Jalgaon district (India). To test the hypothesis a field survey was conducted, where 115 respondents were interviewed including smallholder banana farmers and traders. The responses obtained through field survey were analyzed to get information related to knowledge of ICT tools, comfortable in using of local language for ICT, awareness and need for ICT in banana farming production. Hence it has been concluded that majority of traders don't have effective traceability system and farmers are completely unresponsive about ICT tools.

The second experimental study (in section 5.2) is dedicated to provide Indian farmers a new type of online web-based traceability portal, which would be useful for food operators, logistic providers and consumers. This portal as explained in the chapter, would save time and cost in building up traceability system for Indian food sector, wherein tracking and tracing information of food products using webserver and web API technology can be easily obtained. Thus, with the help of this portal, the country's smallholder farmer will raise their annual income, and it improves the processes of fresh food products supply chain in India.

The chapter titled as "Final Conclusions" provides a summary of what has been covered in this thesis and highlights the findings. Being the most important, that direct selling of farm produce is the best way to increase the income for the farmers which has found in survey area in Jalgaon district. And the web based traceability portal provides farmer with access to business opportunities at farm gate without linkage of any brokers in India.

Finally, some suggestions for future research are presented. For keeping improving food traceability systems in India; guidance should be provided for small-scale food producers on internal control and development of effective risk management. Also, efforts need to be made to 
increase awareness on the ways to use and access product traceability information with the help of digital technology; and finally, focus should be made on the installation and development of the public web server and web APIs for an effective traceability control. 
PhD Thesis

Keshav Prakash Dandage

Introduction

4| P a g e 


\section{Chapter 1}

\section{Introduction}

Food is vital to sustain life as it gives us energy to grow, function and develop. Hence, food safety is the most important priority for public health system across the globe. When food becomes harmful for people and environment then the nourishment gets ceased as well. A recent report published by World Health Organization (WHO) on December 3, 2015 gives an overview of existing victims of unsafe food preparation practices. As per the WHO survey, every year food poisoning (Foodborne Diseases) causes an estimated 600 million illnesses and 420000 deaths globally, moreover, foodborne diseases create barrier in socio economic progress of the country and it spreads fear in the minds of customer, distributor, manufacturer and traders (WHO, 2007, 2015). As suggested by Food and Agricultural Organization (FAO), with the support of mandatory regulatory approach comprising of preventive and educational strategies along with collaboration and shared responsibility between all citizens of the world, would lead to food safety and effective food control system in food supply chain (FAO, 2003).

In today's modern techno-savvy world, many countries, particularly Western and European, have developed numerous preventive methods, and have managed to establish effective food safety programs, like the General Food Law Regulation (EC) 178/2002, GS1 (Global Standards One) 
PhD Thesis

Keshav Prakash Dandage

Introduction

Standards and USA's (United States of America) Food Safety Modernization Act (FSMA). However, major area of world is still lagging behind in this whole concept of food safety, which includes African, Pacific and Asian countries except India, China, Japan, Malaysia, and Taiwan.

Recently Ministry of Food Processing and Industries, Government of India, hosted "World Food India 2017", one of the largest agro-food fairs worldwide. According to FSSAI, this grand fair was attended by over two thousand people, fifty global CEOs and thirty countries across the globe participated in this fair including 8,000 business to business (B2B) and business to government (B2G) meetings were held. The main focusable area of this world food India fair was "food business and food processing value chain from farm to the fork" including food safety, food processing and supply chain, wastage of food, farmer's income level and farm production (FSSAI_WFI, 2017; worldfoodindiA, 2017).

Since, the enactment of the "Food Safety and Standards Act ( FSS), 2006", major changes have taken place in food laws which set up the new arena for agro business in India which serves as the focal point of survival in India. The FSS Act, 2006, established food safety and standards authority of India (FSSAI) which consolidates and unifies nine existing laws into single regulatory agency. In India FSSAI has laid down science based rules, regulations, standards and other instructions for articles of food and has taken measures to regulate the manufacture, storage distribution, sale and import of food products and has ensured the availability of safe and wholesome food for human consumption (FSSAI, 2017).

According to Agarwal, Chief Executive, FSSAI, In India near about 90 percent food business operators are not registered with FSSAI or simply non-food license holder, and remaining 10 percent of total 50 million food business operators, have licenses and registrations of food businesses under FSSAI (TheHindu, 2016). Despite low registration rate of food licenses with FSSAI, the evolution of food safety laws in the country has further led to the expansion of Indian food market globally. As report published by Yes Bank and The Confederation of Indian Industry (CII) in February 2016, India has obtained second position in the total food production and has maintained its first rank in the production of milk, bananas, mangoes, guavas, papayas,

$$
\text { 6| P a g e }
$$


PhD Thesis

Keshav Prakash Dandage

Introduction

ginger and okra. Simultaneously, India also ranks 2 nd in the world in production of green peas, potatoes, tea, tomato, sesame, and this food processing sector has a total of 37,175 registered units with fixed capital of nearly United States Dollar (USD) 24 Billion and aggregate output of around USD 114 Billion. Major industries constituting the food processing sector in India are grains, sugar, edible oils, beverages and dairy products (Yes Bank, 2016).

Tracking and traceability: Using IoT and ICT for food security and safety in India.

This section deals with the use of information and communication technology (ICT) and Internet of thing (IoT) as an important pillar for food security and safety in India in the current scenario of a rapidly changing world. In recent times, food product safety has become an important factor in global market, where consumers strongly ask for evidence of traceability (Opara, 2003). In India increasing population, food prices, food securities issues and decreasing rate of food production all together have impacted on the Indian livelihoods (Dandage, Badia-Melis, \& RuizGarcía, 2017). The poorest populations of India spend a larger proportion of their income on purchasing basic food items. Thus, there is a need to monitor all these issues and provide data to decision makers on food security (Budde, Rowland, \& Funk, 2010)and improve the functioning of agriculture markets at national level(Piekarczyk, 2014). ICT can play and important role in addressing these challenges and offer opportunities to farmers to enhance their existing services and sustain and improve their livelihood. It is an open system that freely interchanges the tracking and tracing information with consumer, producer, distributor and suppliers, whereas it gives the accurate and timely products information using digital technology like ICTs and IoTs (Ruiz-Garcia, Lunadei, Barreiro, \& Robla, 2009).

As IoT grows and evolves, it has tremendously usability and applications in several sectors; in addition, it has ability to finding solution on the real-time challenges which is easily observed in India where agriculture is still dependent upon natural factors. If ICTs and IoTs are appropriately deployed, they can prove to be important pillars of agricultural practices in India and help farmers to manage farms, crops, greenhouses, farm vehicles, and cattle. It can prove beneficial to 
increase the farm yield, which has lowest as compared to western countries, up to 15 per cent(Jeff Hawn, 2015; sadare, 2016).

These advance technologies have impacted over life style, travelling, and working, while many global internet biggies including Google, yahoo, Microsoft, Apple, Amazon, eBay, Facebook, Twitter, and WhatsApp have emerged and introduced large number of innovative services in global market (Hong, 2014). However, use of social media in agriculture and allied sector is still at very early stage. New interactive media such internet and mobile data services have traditionally not been used in rural areas due to low usage rates. The spread of low-cost smartphones and of education will play a big role in making the smartphone the main way in which India will access the internet.

\section{Digital technology initiatives in Indian agriculture sector}

In India, Agriculture sector is being transformed speedily by means of new innovative information technology (IT) initiatives (Banerjee, 2011). Recent mobile and internet based technology is widespread among native people of all ages. In short time government and private sectors have launched numerous initiatives in support of Short Message Service (SMS), Multimedia Messaging Service (MMS), and Voice streaming services (Kokate \& Singh, 2013); some of these have categorized according to their purposes, and operational readiness (Meera, Jhamtani, \& Rao, 2004).

According to Kemp (2015), millions of Indian populations are accessing the widely used Social media platforms including Facebook, Twitter and WhatsApp. India is the second most social media used country after US where number of active users of social media is increasing rapidly, accounting for almost 134 million active social media users and 97 million active mobile social users (Kemp, 2015). In addition, as reported by Internet and Mobile Association of India (IAMAI), there are approximately 220 million active smartphone users in India, and on an average 371 million population of India are getting benefit of mobile internet every year, and this 
figure is continuously increasing day by day, where $1 / 3$ rd user comes from urban area and remaining from Rural areas of India (A. Shah, Jain, \& Bajpai, 2015; TheIndianExpress, 2016).

Table 1.1: Latest digital technology Initiatives for Indian Agriculture sector

\begin{tabular}{|l|l|l|l|}
\hline \multicolumn{1}{|c|}{$\begin{array}{c}\text { Web Portal Based } \\
\text { (Computer) }\end{array}$} & \multicolumn{1}{c|}{$\begin{array}{c}\text { Mobile Based } \\
\text { (Android / iPhone ) }\end{array}$} \\
\hline Government & \multicolumn{1}{|c|}{ Private } & \multicolumn{1}{c|}{ SMS Service } & \multicolumn{1}{c|}{$\begin{array}{c}\text { MMS and Voice } \\
\text { Stream Services }\end{array}$} \\
\hline Agrisnet & iKisan & Nokia Life Tools & m-Krishi \\
\hline Agmarknet & e-Chaupal & $\begin{array}{l}\text { Microsoft Research } \\
\text { India }\end{array}$ & $\begin{array}{l}\text { Airtel (IFFCO Kisan } \\
\text { Sanchar ) }\end{array}$ \\
\hline e-Krishi & $\begin{array}{l}\text { Mahindra Kisan } \\
\text { Mitra }\end{array}$ & e-Sagu & IKSL \\
\hline Ghoomi & Agriwatch & Reuters Market Light & vKVK \\
\hline Warana & Drishti & Kisan Call centre & Digital green \\
\hline Digital Mandi & Marahaat & Fisher friend & Voices \\
\hline
\end{tabular}

Sources: (Arunkumar K R, 2010; Dandage et al., 2017; Kokate \& Singh, 2013; S. Singh,

Gummagolmath, \& Sharma, 2011)

Recently Indian Agriculture sectors have got a new direction and vision by initiating major national level programs using remote sensing technology which include Forecasting Agricultural output using Space, Agrometeorology \& Land based observations (FASAL), National Agricultural Drought Assessment \& Monitoring System (NADAMS), Coordinated Horticulture Assessment and MAnagement using geoiNformatics (CHAMAN), and Krop Insurance using Space technology And geoiNformatics (KISAN) (S. S. Ray, 2016).

In addition to the above-mentioned developments, Indian Space Research Organization (ISRO) has also developed the new android hailstorm app to assess crop manage, as well as it collects data from hailstorm with help of satellite, drone-based imaging and other geospatial technology

$$
\text { 9| P a g e }
$$


PhD Thesis

Keshav Prakash Dandage

Introduction

(mkisan, 2015; TheHindu, 2015). Further, as per report published by FAO, Indian based Ossian Agro Automation has initiated numerous wireless automation system for rural areas especially for irrigation purpose, and its mobile technology helps farmers to turn water pump on and off from any distance through cell phones or landlines. This has opened the new gateway for smallholders' farmers who lives in rural areas devoid of basic facilities like water, electricity and transportation which makes monitoring farms in any hour of the day especially in wild animals' habitat impossible for them(Sylvester, 2015).

Furthermore, under digital India initiative, FSSAI has recently introduced three web-based portals in order to provide safe and secure food for people and increase the food business in food processing and supply chain sector. These portals are accessible from anywhere and anytime using any internet browsers like Internet Explorer, Google chrome, Mozilla firefox etc. and devices like mobile, tablets, and Laptops (Personal Computer). These portals mainly include Food Safety Compliance through Regular Inspections and Sampling (FoSCoRIS), to be used by food safety officers, however an offline Investigation and audit (inspection) of food business for food safety practices are conducted under Food safety officer, as of now it has become digital inspection, and safety officer only need to have an internet connection to verify compliance of food safety standards and Food safety law by food businesses (FoSCoRIS, 2017). Food Regulatory Portal, according to FSSAI, this portal is specially designed for food businesses, and provides fully online services like licenses and registration system at single window, both domestic and food imports operations are possibly done, in order to increase the food safety in country and lowering down the burden of compliances, additionally portal has linked to websites of national agencies like legal metrology, customs, plant and animal quarantine, the Bureau of Indian Standards (BIS) and Agriculture Marketing (AGMARK) for easy assessment of information (FSSAI_FRP, 2017). And Digital Laboratory portal, it's also known as Indian Food Laboratory Network (InFoLNet) which provides a single unified platform for nationwide sharing of intra laboratory food testing data under lab management system, and It gives an open access to any user across the country(FSSAI_INFoLNET, 2017)). 
Digital and smart technologies have thus led to the expansion of today's food business and brings an end to all old policies and procedures to deal with specific problems, in addition, last year the Quality Council of India has initiated two new certification schemes such as IndiaHACCP (hazard analysis and critical control points) and IndiaGHP (good hygiene practices) which is beneficial for domestic food business operator. These certifications are mandatory to all food business for production of safe and suitable food and would help to minimize the food risk, and increase food safety in the interest of public health and growth of food business at local level(QCIN, 2017). 
PhD Thesis

Keshav Prakash Dandage

Problem Statement

12 | P a g e 


\section{Chapter 2}

\section{Problem Statement}

This chapter gives brief information about problems which has extensively affected to Indian food sectors and unbalanced their routinely activities, however the adoption of ICT and traceability system are also behaving abnormally due to number of crises and illiteracy, presenting the Statement of the problem and why it should be solved.

\subsection{Lack of food traceability control system in India}

As informed by authors that in the current Indian open market, large number of traders and smaller land holdings farmers gather to sell and buy food commodities. However, quality of product and product identification, both are very difficult to be traced in such places where thousands of farmers and traders gather to deal in the commodities. In many market places brokers purchase the food commodities from multiple farmers and at the end same categories of food commodities are mixed into each other. Thus, in such places traceability food safety preventive measures needs to be applied to prevent further food loses and to maintain food quality (Bhat, Science, Food, \& Problems, 2005; Unnevehr, 2015).

According to Sharma et al. (2017), the loose connectivity between government agencies and small medium food industries which has led instability and complexities in market that are 
unknowingly spoiled the working method of market. Moreover, the combination of incomplete information and poor infrastructure which has also made difficult for manufacturer to produce the right product to consumer, because supply chain process is consisted of various steps which requires an effort and resources to keep track of every process. Hence, Indian manufacturer gives a low priority but, in most cases, the associated high cost of electronic devices like Radio Frequency Identification (RFID), barcode, reader machines, and other monitoring tools become constraint for small scale industries. In order to succeed, market needs to be structured in a carefully way with help of controlling management system so that it can easily control the complex market behavior(Sharma, Y. K., Mangla, S. K., Patil, P. P., \& Uniyal, 2017).

Prakash. G. (2015) writes about the inability and stressful situation for traceability system in India due to less developed laboratory infrastructure network of inspection, weak performance in analytical methods for food inspection and food safety controls relating to domestic production and consumption. Nevertheless, a risk assessment model and mechanism have not been well established, and the government authorities responsible for the management which is not wellcoordinated.

According to Dandage et al., (2017), since decade high number of homegrown businesses have increased in India, and all raw materials are sourced locally. In most cases these operators are found to be without food licenses under FSSAI, and that is a responsible factor for food adulteration and food fraud. Hence, such local food business operators are responsible to bring an unsafe food into market which widely affects the life of consumers. Moreover, mostly countryside areas are indulged in such activities, where system finds many difficulties to locate the source of affected products.

According to Mudda et al. (2017), there are many broken linkages in agriculture supply chain from production house to further processing and marketing; each segment works on individual level which results in losses of bulk products across food supply chain. In production segment, key factors are poor extension, less quality inputs which gives rise to low productivity, as well as improper post-harvest management. In supply chain, shortage of storage facilities like cold 
chain, and storage houses has resulted in large amount of wastage of fresh produce. Heavy overcrowding in market area that takes time to reach, as well as poor transportation, packaging of foods and food safety are another major concerned. In processing and marketing unit, the major problem areas are absence of infrastructure and technology, lack of quality and graded material, prices variables and lack of transparency in market rate, and time-consuming delivery system from producer to retailer.

Food supply chains variables and their inter-relationship studied by Faisal 2016, showed that major food industries are lagged behind in the manufacture excellence along with less availability of a higher level of technical skilled labor. This is creating an obstacle in handling essential parameters for developing effective traceability system such as coding equipment, industrial bar code scanners, and large amount of servers which is needed to store data to enable an immediate access to data, and trading information (Faisal \& Talib, 2016).

\subsection{Organization of the Indian food sector}

According to India Brand Equity Foundation, despite large amount of agricultural production, only less than 10 percent of all the food produced in India goes to organized food industry for processing into value added products, and rest of food is either utilized by local food operators, public or wasted. In India, more food market are occupied by unorganized sector and small scales food industries which accounts for 75 percent, and these food industries are rarely registered under FSSAI. Indian food processors and exporters lack of local compliance with food safety standards demanded by the major importing countries of the world (IBEF, 2015).

However, In India majority of populations are engaged in purchase of dairy, baking product, oils and fats-based food products from unorganized sectors, which has resulted in the increase in sales and earnings at large extent. According to Dandage et al.(2017), traditional family owned outlets( Kirana Stores) are the main responsible factor behind sales of overall packaged foods, rather than supermarkets in India, typical grocery stores have covered largely areas and works on demographic trends of India which is essential for Indian consumer, additionally near about 70 
percent population is resided in countryside area, hence it's a major challenges for packaged food retailers and manufacturers to get into village area and prepare food products as per their requirement to increase and boosting up sales.

According to Roy, M., \& Kumar, S. (2012), there is inconsistency in country's state and central laws on food processing sector, which further discourages the investor to enter in food sector. Additionally, poor infrastructure like cold storage, warehouses, and transportation, poor technology and practicing of traditional methods make this food sector very weak. There is no specific policy for contract farming that would address the loop holes in Agricultural Produce Market Committee (APMC) act to make raw materials easily available, along with no financial support and capital investment of foreign direct investment (FDI) or home department in this sector.

Pant et al. (2015), studied over transparency and traceability issues of dairy supply chain networks, and found the poor development in dairy supply chain management, low grade milk testing laboratories in rural areas, along with lack of Adoption of tracking and tracing devices on milk transportation van, and non-availability of barcode on milk packaging. Similarly, Kumar et al. (2011) conducted a survey in India, found that there is no direct measures of milk safety, along with absence of legal written contract with milk seller. All activities are happened only based on trust and oral conversation between the buyers and sellers of milk. However, many local and cooperatives dairy are highly inter connected to each other, and it gives less attention towards the quality and safety of milk, and adoption of food safety practices.

\subsection{Adoption of ICT tools in Indian farmer}

The farmers in India are totally unaware about the existing services and various facilities of new technology, which is mostly cited in English language rather than local language. For accessing information farmers need to be purchased the ICT tools that are really costly as compared to newspaper. Mittal et al (2010) in his study found that farmers are mostly get accessed to old and 
routine information, which is loose the interest and farmer decides to quit the process because could not find the user friendly and new updated information.

Thus, Indian farmer's literacy is the major impediment in using the ICT tools. Only mobile phone, radio, and television are the most common ICT tools to accessing information, as well as lack of ICT skills, lack of ICT infrastructure ( High speed internet connectivity), fear and distrust of technology, lack of training and traditional practices are also major factors behind adoption of ICT (Chandra \& Malaya, 2011). 
PhD Thesis

Keshav Prakash Dandage

State of the Art

18 I $\mathrm{P}$ a g e 


\section{Chapter 3}

\section{State of the Art}

In section below, the necessity for a proper traceability in the Indian food industry is exposed, because the sector needs an adequate system due to the precarious nature of existing supply chain, and to reduce the numerous cases of food safety incidents and fraudulence. This work also presents the existing traceability techniques in India which include RFID, Holograms, Barcode, Nuclear techniques and other tracking media to monitor production process. Furthermore, it is revealed the initiatives implementation from APEDA and its association with GS1 India in the form of Anarnet, Peanut.net, Meat.net, and Grapenet for the Indian farming products, as well as several ICTs initiatives that are actively working in many states of India

This section has been published in journal of food control. Dandage, K., R. Badia-Melis, and L. Ruiz-García (2016). Indian perspective in food traceability: A review. Food Control 71 (2017): 217-227.

3.1 Necessity of traceability in the Indian food industry

Functional role of the traceability system within Indian food supply chain 
In the last half decade 2009-2013, the exports of India has risen at annual rate of $6.6 \%$ (OEC, 2015), so far India has been exported many farming products such as mango, banana, onion, ladyfinger, pomegranate, and more to many parts of world under the guideline of Agricultural \& Processed Food Products Export Development Authority (APEDA), and AGMARK (APEDA, 2013a).

FSSAI aims to give a comprehensive view to food business operators in terms of behavior of food recall portal, as well as how they should be carried out a food recall portal in order to develop an efficient rapid identification system, removal of unsafe food, and preventing customers from potentially hazardous food in market (FSSAI, 2011a). This is to take traceability as an integral part of food logistics (Bosona and Gebresenbet, 2013).

Although India does not have any obligatory traceability system (Schroeder et al, 2012), but nevertheless in recent years Indian government has been started to work with private entities, state and central governments, which include FSSAI, APEDA, GS1 India, National Bank for Agriculture and Rural Development (NABARD), food products order (FPO), India Tobacco Company's (ITC) eChaupal, and Reliance industry etc. for developing the traceability system within the Indian food industry and food supply chain, moreover paying attention towards trade and distribution of the agriculture products in cost effective ways to compete with global market (Jacques and Zuurbier, 2008).

Traceability reduces public costs like medical, and private costs like product recalling (Abbot, 1991; Hobbs et al., 2005), helps to obtain the rich profit by reducing the labor cost of reading code, reduce goods in stock, and reduce the occurrence of larceny (Biederman, 2006), reduce distribution costs (Michael and McCathie, 2005), reduce operating and storage costs (YongDong, S et al., 2009), ensure the quality of production and products (Wall, 1994), increasing food safety and security (Anica-Popa, 2011), ensure consistent quality of food products and prevent food safety problems ( $\mathrm{Li}$ et al., 2006), gives accurate, timely, complete, and consistent information about products (Regattieri et al., 2007), reduces labor productivity losses 
(Veronneau, and Roy, 2009), save time and money (Moe, 1998), reduce human error (Frederiksen et al., 2002).

Fundamentally, India requires more development in current national food laws, as well as need to adopt an effective traceability system in order to improve and change within current food industry and food supply chain. As suggested by researchers the following factors are essential to control the food outbreaks and fraud, in order to establish the new food traceability legislation in Indian food industries.

\section{Food Safety Incidents and hazard identification in India}

In India, the main principle cause behind increasing food safety concern is the inconsistency and arbitrariness in food safety monitoring system, for example the problem of antibiotic in honey (Narain, 2010), growing the use of milk adulterants and tainted meat (Biswas et al, 2015).

Small dairies and household dairy stores, utilizes nearly large amount of processed milk for preparing traditional Indian dairy products (IAI, 2011; IBEF, 2012), and these products are highly perishable and being packed without using any aseptic packing conditions (Dabbene et al., 2014), whereas, difficult to trace the source of milk from which the products have been made and fail to meet international safety, packaging and transparency standards due to lack of investments, equipment and technology (Gupta, 2007; IAI, 2011).

European Union temporarily banned on export of Indian food items, which include alphonso mangoes, eggplant, the taro plant, bitter gourd and snake gourd due to fruit flies, antibiotic residues, cadmium and vibrio (Sonwalkar, 2014).

As reported by Food Standards Australia New Zealand (FSANZ), Australian based Indya Foods Pty Ltd has recalled Indian based company Haldiram's food product such as Tasty nuts from Indian and South Australia supermarkets, because of contamination with aflatoxin, a highly toxic compound (FSANZ, 2013; Chandra, 2014). Food and Drug Administration (FDA) also 
renounced the food products from Haldiram because of high levels of pesticides, mold and bacteria (Newsdesk, 2015).

In 2012 FDA recalled the frozen tuna fish of Moon Fishery from India, due to the presence of Salmonella in sampling strips (Rothschild, 2012). Whereas, in 2010, Russia banned on export of Indian bovine meat as well as enforced many limitations on exporting products from Indian origin (Radyuhin, 2010).

Major problems are associated with street vendor food; firstly Mahale et al (2008) studied over sugarcane juice, lime juice and carrot juice found with high load of coliforms, fecal coliforms, vibrio, and staphylococcal counts. Whereas secondly, Das et al (2010) studied over Indian chatfood, which is very famous street food and found loads of bacterial pathogens such as S. faecalis, E. coli, S. aureus, Bacillus spp., Klebsiella spp., and Pseudomonas spp.

\section{Food fraudulence in India}

In India, recently the milk scam was disclosed in which powder and saturated fatty oil were mixed with milk for increasing the sale of milk (Paul, 2016), whereas Indian authorities discovered in their study that most milk manufacturers were diluted or contained by unappetizing agents such as hydrogen peroxide, detergent and urea (Banerji, 2012).As per the prevention of food adulteration Act, 1954, which comes under FSSAI (2011b), usage of toxic chemical in food is prohibited, however some retailer mix the yellow colored rice bran or lead chromate with turmeric powder to increase its quantity, as well as another oil is argemone which is mixed with mustard oil. Pulses also adulterate with Keshari dal (Mishra, 2010), however most common food frauds involve is to change the essential ingredients with something of lesser value, wherein effective traceability, regular audit and reconciliation measures can assist in preventing fraud and theft of food items.

\subsection{Effective traceability techniques in India}


In India, existing product identification technologies are alphanumerical codes, Hologram, Barcode, RFID tags, and the geographical indication (GI) tag. In the near future, recent food traceability techniques, such as Bio tracing, Nano sensor, global positioning system (GPS) and geographic information system (GIS) would be utilized by India. Nevertheless, in order to understand the principle of operation of traceability system, a deep knowledge of the interaction of harmonized traceability techniques with transparency is required.

Definitely the new and efficient traceability systems can control the human error as well as creating more awareness of food quality standards, and result in savings at some level of the supply chain (Furness et al, 2003; Larsen and Lees, 2003). In India, The food traceability market is being increased with the growing understanding for food safety among the consumers and government authorities.

In the last year, Cargill announced that its going to build a $100 \%$ traceable and sustainable supply chain of the palm oil in India by 2020 (Cargill, 2014), whereas recently started the food safety awareness program across the country under the Surakshit Khadya Abhiyan (Cargill, 2015).

In recent year Tea Board of India introduced, Trustea and Rain Forest Alliance (RFA) certifications, which are mandatory for all tea manufacturers in order to set up the transparency, reliable supplier of tea and traceability in both domestic as well as overseas market, but nevertheless only one tea factory has obtained all certifications (Kumar, 2015).

McDonald restaurants recently introduced the food traceability for potatoes to keep a track of the product sources from 40 different suppliers across the country in order to provide food safety and quality (McDonald, 2015).

Numerous farm products like grape, mango, banana, onion, potato, soybean and poultry are able to increase the economy of small holder farmers as well as those could change the face of Indian farming sector, whereas few of them are certified by APEDA, so which can be easily traceable and identified in Indian market (APEDA, 2013a). 
Following modern traceability systems are currently being used across Indian food industry and other sectors:

\section{Alphanumerical codes in India}

Traditional food deliverymen has paced into forward and using a system of alphanumeric codes printed on reusable containers for easily identifying and supplying fast service to their customer (Narayan, 2016). According to Regattieri et al. (2007) alphanumerical codes are a combination of the alphabetic and numeric characters of different sizes, which is generally found on products label, whereas it is very lucid, and non-mechanized process (Abad et al., 2009).

\section{Hologram in India}

As reported by Agrawal Arun (ASPA, 2015), general secretary, Authentication Solution Providers' Association (ASPA), in Rajasthan State (India) where few departments and brand owners are being employed the authentication solutions, wherein Rajasthan State Food \& Civil Supplies Corporation are also focusing on food safety and notified to use a security hologram on daily household food items like tea, salt, pulses, Spices, and atta (wheat flour) etc. (ASPA, 2015). According to Barger et al (2000) a precise definition of hologram is a physical structure that diffracts light into an image, while it refers for both the encoded material and the resulting image. In addition, it is an effective product authentic solution which empowers to consumer, brand owners and government authorities to easily identify genuine products against to fake.

\section{Barcode in India}

Major food processing companies including the Dabur food, Godrej beverages \& foods, Amul, Hindustan Unilever, ITC, Kohinoor food, Mother dairies and Venkys India (Shah ,2011) are using the barcode and 2-D quick response (QR) code techniques in order to develop an effective authentic product solutions, while assisting to build up a confidence in customers. In addition, the growing retail sector is also responsible for emerging this segment, whereas continuously asking for distributors, manufacturers to adopt the barcode system for their products. 
Recently APEDA adopted the GS1 standards, while most of the more visible and useful applications have been achieved through the usage of GS1's product identifiers in barcoding for Grapenet, Anarnet, and Tracenet. Additionally APEDA, it is an agro trade promotional body of the government of India, and has already been providing traceability services to improve the confidence of importing countries in Indian agricultural products (GS1 India, 2012). According to Zare Mehrjerdi (2010), barcode is an openly machine-readable data which is printed over the objects, whereas by means of electronics barcode readers can be easily encode, store and recall information.

\section{Radio frequency identification (RFID) in India}

Currently in India, RFID technique is being utilized by several dairy industries, including Amul dairy, which uses RFID tagging for milk yielding animal on their Anand farm in Gujarat state, Chitale dairy, which uses RFID tagging for tracking and storing information relating to health issue, and Govardhan dairy, which uses RFID tagging for identifying their cattle by numbers, both from Pune, Maharashtra state (Swedberg, 2010; Rohatgi, 2014).

In their study, Agarwal et al (2014) suggested that a new developed smart ration card using RFID would help to prevent from fabrication in the distribution of ration, which is fixed allowance of provisions or foods like sugar, oil etc. from the ration shops with ration card. At present days, in India both domestic and foreign retailing players like Wal-Mart, Metro, Reliance, Food bazaar, Tata sons, Future groups, and Bharti, have already taken steps towards RFID technology with suppliers to go in for RFID (Srivastava, 2004; Kelepouris et al., 2007).

\section{Document-Based (Paper/Electronic Documents) traceability system in India}

Majorly smaller industries and producers are focused over simple pen and paper for reporting, stock information and communicate data with partners in supply chains. Besides manual process which is time consuming, as well as provide inappropriate information or error with respect to the accurate source, location, or doubtful product, and it is unable to transfer information among partners in the food supply chain because of unavailability of electronic recording and reporting 
system, hence in such case the product information like product lot number, harvest date, product receipt/shipping date, quantity, or ingredients, which is written by manually in the handbook (Karippacheril et al., 2012).

Nowadays, Indian software companies like Infosys, Logisoft, Tata consultancy services (TCS), and Tech Mahindra, which are being assisted toward using the traceability in the form of Enterprise Resource Planning (ERP) systems, that can be used for storing data and inventory control, warehouse management, accounting, and asset management. ERP systems can read standardized data from barcodes and RFIDs, including global trade item numbers (GTIN) and global location numbers (GLN) (Karippacheril et al., 2012).

\section{Nuclear Technique in India}

The basic features of the nuclear technique is to determine of food provenance (IAEA, 2011; Simon, 2015), the nuclear techniques like genomic technique and isotopic, both are at ground level in India but consistently going ahead. As reported by Rohit (2016), in short time Indian basmati rice is to be acquired GI tag, which is used to identify the origin, quality and other characteristics of the products, basmati rice cultivated in the region of northern India.

\section{Information and Communication Technology (ICT)}

Several publications have appeared in recent years documenting the emerging ICT in India, where ICTs become very popular and providing easy solution to the farmer, trader, suppliers and even manufacturers too, along with ICTs give fast, reliable, efficient service and real time information in term of the quality and quantity of the agricultural products marketing (Lashgarara et al., 2013). Parwez (2014) also described the benefits of ICTs and informed that farmer can easily forward and sharing the information with other person or system and able to solve information-based problem in short period, whereas Indian agriculture sector is being progressed rapidly and many private as well as public sector with ICTs enabled initiatives. 
In a recent study by Pant et al. (2015) discussed how to use the effective GPS and GIS traceability in order to enhance the efficiency of high quality milk, as well as proposed the lead role of traceability system in monitoring movement of milk distribution vehicle and handling of raw milk as well.

Following ICTs initiatives have been started their outstanding work in many states of India 
PhD Thesis

Keshav Prakash Dandage

State of the Art

Table 3.1: Emerging solutions by private and government sector in India

\begin{tabular}{|c|c|c|c|}
\hline Category & ICTs in India & Information & Source \\
\hline $\begin{array}{l}\text { Extensive } \\
\text { Agriculture } \\
\text { Logistics } \\
\text { Solutions } \\
\end{array}$ & $\begin{array}{c}\text { Sohanlal } \\
\text { Commodity }\end{array}$ & $\begin{array}{l}\text { Company furnishes the warehousing services such } \\
\text { as scientific storage for agriculture commodities, } \\
\text { handling day-to-day operations, fumigation, testing } \\
\text { and certification. }\end{array}$ & www.sohanlal.in \\
\hline \multirow[b]{2}{*}{$\begin{array}{l}\text { Integrated } \\
\text { Cold Chain } \\
\text { Solutions }\end{array}$} & $\begin{array}{l}\text { Cold Star } \\
\text { Logistics }\end{array}$ & $\begin{array}{l}\text { Cold Star provides a customized solution for cold } \\
\text { storage and refrigerated transportation across India } \\
\text { for fresh and frozen commodities. }\end{array}$ & $\frac{\text { www.coldstarlogistics.co }}{\underline{\mathrm{m}}}$ \\
\hline & LEAF & $\begin{array}{l}\text { LEAF provides integrated cold chain logistics } \\
\text { comprising post-harvest transport, cold storage, } \\
\text { processing, and supply through refri-trucks to the } \\
\text { distribution centre and retail stores. }\end{array}$ & www.lawrencedale.com \\
\hline \multirow{2}{*}{$\begin{array}{l}\text { Alternate } \\
\text { Marketplaces }\end{array}$} & e-Chaupal & $\begin{array}{l}\text { It's virtual market place where farmer can transact } \\
\text { directly with processor and can realize better price } \\
\text { for their produce. } \\
\text { Its web based and the portal currently has over } \\
\text { 5,000 kinds of produce listed. }\end{array}$ & www.itcportal.com \\
\hline & efarm & $\begin{array}{l}\text { It provides a way to bypass the long chain of } \\
\text { intermediaries by directly connecting buyers and } \\
\text { sellers of agricultural produce, }\end{array}$ & www.efarmdirect.com \\
\hline \multirow[t]{2}{*}{$\begin{array}{l}\text { Reducing the } \\
\text { Information } \\
\text { Asymmetry }\end{array}$} & $\begin{array}{c}\text { TCS } \\
\text { mKRISHI }\end{array}$ & $\begin{array}{l}\text { Offers personalized advisory services to farmers, } \\
\text { via mobile phones (SMS and IVR) of pesticides, } \\
\text { fertilisers, market etc. }\end{array}$ & www.tcs.com \\
\hline & Reuters Market & $\begin{array}{l}\text { It provides solutions across the entire agro value } \\
\text { chain, agricultural information from pre-sowing to } \\
\text { post-harvest stages through SMS on their mobile } \\
\text { phones in their local language. }\end{array}$ & www.rmlglobal.com \\
\hline $\begin{array}{l}\text { Supply Chain } \\
\text { Management }\end{array}$ & Logistimo & $\begin{array}{l}\text { It uniquely suitable for rural markets, offers } \\
\text { customers the ability to capture and share data in a } \\
\text { simple, low-cost way. }\end{array}$ & $\underline{\text { www.logistimo.com }}$ \\
\hline $\begin{array}{l}\text { APEDA's } \\
\text { Initiatives } \\
\text { in } \\
\text { Traceability }\end{array}$ & Hortinet & $\begin{array}{l}\text { Recently APEDA has initiated the web-based } \\
\text { traceability system for selected horticulture } \\
\text { produces such as grape, pomegranate, banana, } \\
\text { mango, ladyfingers along with their respective } \\
\text { traceability system, wherein Grapenet for grapes, } \\
\text { Anarnet for pomegranate, Peanut.Net for Peanut etc. }\end{array}$ & apeda.gov.in \\
\hline $\begin{array}{l}\text { Dairy } \\
\text { Traceability }\end{array}$ & BG Chitale Dairy & Cattle Tagging in dairy farming. & www.chitaledairy.com \\
\hline $\begin{array}{l}\text { Global } \\
\text { Supply Chain }\end{array}$ & GS1 India & $\begin{array}{l}\text { It registers to company and provides GCP and } \\
\text { GTIN number for systematic and transparent and } \\
\text { easy food supply chain across country }\end{array}$ & www.gs1india.org \\
\hline
\end{tabular}

Sources: Company websites, News reports, 2014- 2015. 


\subsection{Initiatives of traceability systems in India}

\section{Introduction to the GS1 India and data interpretation for product identification}

The simplest way of representing the traceability system is GS1 India, which is an autonomous body under Ministry of Commerce \& Industry, Government of India and founder members including Ministry of commerce, Confederation of Indian Industry (CII), Federation of Indian chambers of commerce and Industry (FICCI), Associated chambers of commerce and Industry of India (ASSOCHAM), federation of Indian export organisation (FIEO), Spices Board, bureau of Indian Standards(BIS), Indian Merchants Chambers(IMC), Indian Institute of packaging (IIP), APEDA and Its affiliated to GS1, Brussels, Belgium along with 114 GS1 Organisation worldwide (GS1 India, 2012; MSME, 2007).

The generic packaged items having fixed weights are identified by produce electronic identification board universal product codes (PEIB UPC) but at this stage the buyer cannot track and trace the product, mostly the trader or grower uses prefix 033383. While the generic loose items or non-packaged items, which are sold in large quantity and identified by means of Produce Electronic Identification Board price look up codes (PEIB PLU), but it does not include any reference number as well as don't know who supplied the product (GS1 US, 2007).

At trade level (trader), where the company uses the GTIN as company prefix and product features. The trader or grower uses generic prefix “033383" with a generic 5-digit item reference number assigned by produce marketing association (PMA), for example "033383000016" (GS1 US, 2007).

GS1 India also guides to company to register their saleable / stock keeping (SKU), in order to get unique identification number, global company prefix (GCP), as well as item reference number or global trade identification number (GTIN-standardized in 14 digits) (GS1 India, 2012).

Traceability systems for Indian Farming produce through GS1 India Standards and APEDA 
In recent years APEDA has been initiated the new electronics traceability system for agro-food safety and emphasized on the application of the information technology in the traceability system for various farming produces, which include grape, banana, pomegranate, ladyfinger and peanut, as well as all farming produces have their independent traceable methods. But a key limitation is that currently it is not mandatory for all farmers or produces except the export point of view as required by particular counties, then certain produce takes to electronic and IT enable traceability system with the regulation, compliance and monitoring though various processes like sanitary and phytosanitary (SPS) measures and AGMARK certifications. For example, Grapenet traceability system for grape, Okra farms for ladyfinger, Anarnet for pomegranate, Peanut.net for peanut or groundnut and Tracenet for organic products, whereas APEDA provides laboratory testing and certification for export and help to tracking and tracing information through its internet-based traceability software system (APEDA, 2013a).

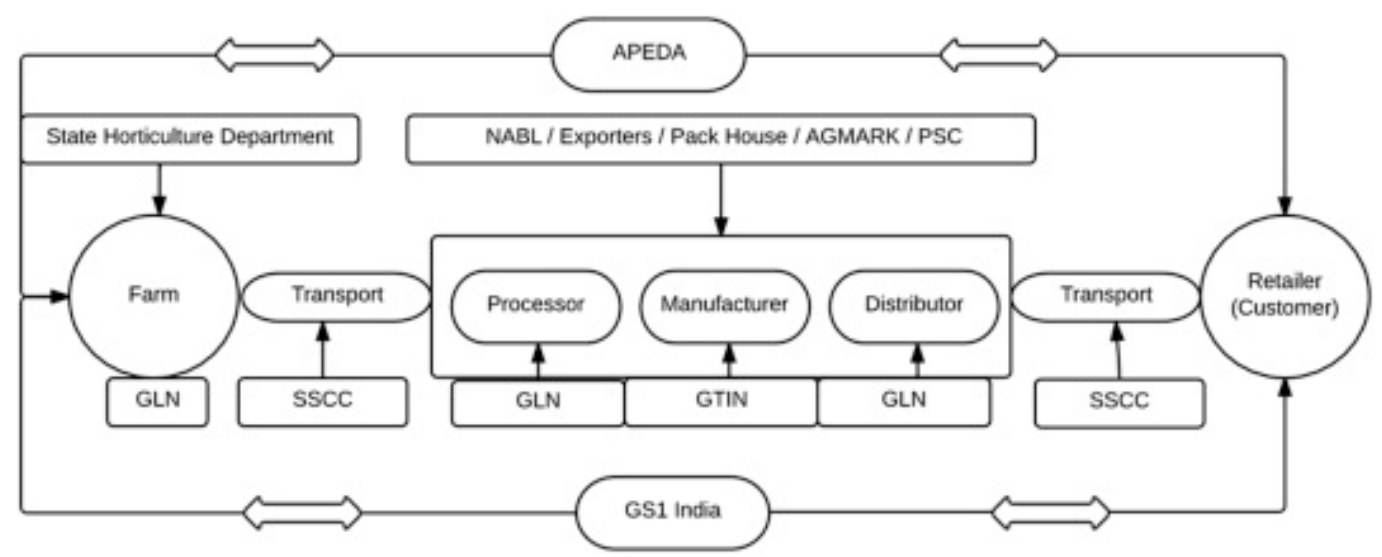

Figure 3.1. Traceability Implementation Model

As shown in figure 3.1, APEDA and GS1 India have together initiated a traceability system for horticulture produces, which include grapes, pomegranate, mango, ladyfinger etc. (APEDA, 2013a). Initially, under APEDA, registration of farms with any district agriculture or horticulture officer of state horticulture department, then farm is inspected by horticulture officers. Besides GS1 India also helps to get registration of farms for specific GLN which identifies a farm or 
Small Medium-sized Enterprises (SMEs) in any part of a food and agriculture value chain (GS1 India, 2012).

\section{Initiatives of traceability for livestock in India}

Recently India has introduced cattle tagging using RFID for dairy farming, which include the organizations Amul dairy, Gowardhan dairy and Chitale dairy (Rohatgi, 2014).

In last few years ago, Chitale dairy tagged around 7000 cows and buffaloes in Maharashtra and Tamil Nadu states respectively (Mathis, 2010; Swedberg, 2010) and currently, as the number of tagging in this run increased up to 50.000 cows and buffaloes, as well as company has targets to capture all animals across the country because of increasing responding from farmers as well as dairy companies from last couple of years (Rohatgi, 2014; D’Monte, 2015). In addition, noticeable thing is that Chitale dairy uses combine passive RFID tag to track cows and buffaloes, which is fitted on each ear of cattle and buffaloes (Rohatgi, 2014; D'Monte, 2015).

As stated by Rao, managing director, in future company is going to launch new way of tracking for livestock system in India as well as other countries. This unique system would provide the national livestock registry to government authorities and customers (Rao CSS, 2012).

\section{Initiatives for seafood traceability in India}

Recently Indian Society of Agribusiness Professionals (ISAP, 2015) published that, soon the Indian aqua farms for shrimps, and other species are going to be traceable. In addition, as reported by Rajkumar Gollapalli, National Fish \& Seafood Aquaculture and Sustainability specialist, this aquaculture traceability brings an tremendous change, and solve the critical work in moment, as well as it is faster, easier, reliable, and efficient (Shawna, 2015).

\subsection{Estimated cost for food traceability in India}

In the last few years APEDA has been shown growing interest in electronic traceability system for farming products such as grape, banana, mango, pomegranate, and ladyfinger, simultaneously 
provide the guideline to the farmers about good agricultural practices as well as focusing over the food safety standards for improving better production and distribution (APEDA, 2013). Nowadays, building up traceability system in Indian firm has become easier with help of APEDA, AGMARK, and GS1 India. Traceability system can provide the maximum yield to the firm and beneficial investment. According to Golan et al. (2004), eventually cost is the main matter in order to adopt advance and safety traceability system for the small, cottage industries and many producers, distributors and processors. Moreover, the firm's traceability costs consist of equipment and technical costs, labor costs for food safety assurance, testing and traceability management like breadth, depth, and precision of the traceability system which is broadly connected with food and feed products from source to sale in food supply chain.

The following data collected through technology providers and available traceability related products in market, because each firm faces a different set of costs depending on its circumstances and nature of products. While another factor appears that estimated costs have been categorized into fixed cost, where expenses that are not dependent on the activities of a firm as well as it is one time initial costs, and secondly, variable costs where expenses that change in proportion to the activities of a firm like product volume and size of firm, also which is used to achieve other purposes, such as labor, management, paper or faster delivery times and computer system not to be included. Nevertheless, RFID tags are costlier than barcode, but completely depending upon choice of firm whether passive or active tags (Ruiz-Garcia and Lunadei, 2011). Also require the RFID-enabled label printers, readers, antennas, software, middleware, and computers. Using barcode, it is simple as well as can be easily printed on regular printer and save huge money. Furthermore, annual and renewal fees both are cost per year of owning and operating the system and it's required to pay for commencing year after year service of the systems. 
PhD Thesis

Keshav Prakash Dandage

State of the Art

Table 3.2: Estimated cost for Indian traceability system

\begin{tabular}{|c|c|c|}
\hline Type of cost & \multirow{2}{*}{$\begin{array}{l}\text { Estimated cost } \\
\quad \text { (in dollar ) }\end{array}$} & \multirow[t]{2}{*}{ Comment } \\
\hline 1. Fixed cost & & \\
\hline Farm registration & 0.80 per farm/plot & Under district agro / horticulture Officer \\
\hline APEDA Registration & 80 & $\begin{array}{l}\text { For Export under Hortinet, Anarnet, Grapenet } \\
\text { etc. }\end{array}$ \\
\hline CAG certificate & 3 & Under AGMARK \\
\hline $\begin{array}{l}\text { Certificate of Authorization (C.A.) } \\
\text { for grading of fruits and vegetables }\end{array}$ & 15 & Under AGMARK \\
\hline Warehouse Registration & 250 & $\begin{array}{l}\text { Under APEDA, for all food produces except } \\
\text { grapes. }\end{array}$ \\
\hline $\begin{array}{l}\text { GS1 India Registration for } \\
\text { Company prefix }(\mathrm{GCP}) \text { and GTIN } \\
\text { number } \\
\text { * Small } \\
\text { (turnover upto } \$ 160000 \text { ) } \\
\text { * Medium } \\
\text { (turnover upto } \$ 1600000 \text { ) } \\
\text { *Large } \\
\text { (turnover upto } \$ 16000000 \text { ) }\end{array}$ & $\begin{array}{l}662 \\
871 \\
1093\end{array}$ & $\begin{array}{l}\text { GS1 India } \\
\text { Registration costs depending upon the firm } \\
\text { size and its annual turnover and it has } 1 \text { year } \\
\text { validity or onwards } \\
\text { And it includes registration fees, subscription } \\
\text { fees, security deposit and service tax etc. } \\
\text { Only } 9 \text { digits UPC prefix for } 100 \text { barcodes }\end{array}$ \\
\hline $\begin{array}{l}\text { GLN no. Registration } \\
\text { (under GS1 India) }\end{array}$ & 8 & Under GS1 India \\
\hline \multicolumn{3}{|l|}{ 2. Variable cost } \\
\hline Residue analysis & $50-150$ & $\begin{array}{l}\text { Under NHRDF, depending upon type of fruits } \\
\text { and vegetables. } \\
\text { http://nhrdf.org/en-us/Services }\end{array}$ \\
\hline $\begin{array}{l}\text { 2.GS1 India (Renewal fees) } \\
\text { *Small } \\
\text { (turnover upto } \$ 160000) \\
\text { *Medium } \\
\text { (turnover upto } \$ 1600000 \text { ) } \\
\text { *Large } \\
\text { (turnover upto } \$ 16000000 \text { ) }\end{array}$ & $\begin{array}{l}135 \\
154 \\
185\end{array}$ & $\begin{array}{l}\text { Renewal fee for } 1 \text { year and } \\
\text { Only } 9 \text { digits UPC prefix for } 100 \text { barcodes }\end{array}$ \\
\hline RFID tag & $\begin{array}{c}\text { Active: } \$ 5.0 \text { per tag } \\
\text { Passive: } \$ 0.16 \text { per tag }\end{array}$ & $\begin{array}{l}\text { Depend upon the choice of the firm to be } \\
\text { required either active or passive tag }\end{array}$ \\
\hline $\begin{array}{l}\text { barcode label pre-printed or own } \\
\text { printed on site }\end{array}$ & $\$ 0.005$ per label & General data \\
\hline Barcode scanner & 40 & Amazon online retailer \\
\hline RFID tag Reader & 50 & Amazon online retailer \\
\hline Printer & 50 & Amazon online retailer \\
\hline
\end{tabular}

Source: APEDA, AGMARK, GS1 India, Amazon online Retailer, NHRDF. 
Table 3.2 indicates that calculated costs can be assisted to establish the partial traceability system for Indian small and cottage food industries. In order to better development and adopting barcode system for products, already the Indian government has announced the financial assistance scheme for registered micro and small manufacturing enterprises, where the eligible units to claim reimbursements of 75 percent of the one-time registration fee and 75 percent of the annual fee paid to GS1 India for the first three years, against proof of payment (MSME, 2007; GS1 India, 2012).

\subsection{Impediment for adoption and challenges of food traceability in India}

Recently, considerable attention has been given to Indian farming sectors, which are being progressed gradually, and many organized sectors are being grounded day by day, but nevertheless the food safety and product recalling problems remain steady because of some parameters such as structural, institutional, technical, cultural issues, which affect to settle the food traceability in India, whether for the domestic market or for export trade (Umali-Deininger and Sur, 2007). The main responsible factors that affect food traceability in India are shown in the present section.

There are plenty of smallholder farmers and marginal farmers in India, near about 100 million of small holder farmers have engaged in farm cultivating area with average farm around 1 or 2 hectors either fertile or unproductive, while rate of literacy among small holder farmers are low (FAO, 2005).

Mostly Indian agricultural markets are governed under the state Agricultural Produce Market Committee (APMC) acts, which handles more than 10000 regulated markets or Mandi, which is the main source of dealing commodities (Ramakrishna and Ajjappa, 2013), whereas nowadays regulated market is unable to protect and provide as much as facilities which requires to maintain the quality and traceability.

There is a deficiency of grades and standards for domestic market and loose enforcement. However, due to lack of financial budget, many small and cottage industries are unable to 
provide good quality products, and hence such companies must go through AGMARK certification for establishing food standards and grades for their products in domestic market, and proper development of food traceability in India (APEDA, 2013a).

There are inadequate good agricultural, manufacturing, and hygiene practices in India, which makes more difficult for the proper traceability; APEDA is being continuously worked on improving the food safety for domestic and export market, and emphasis on adoption of hazard analysis critical control point (HACCP) and international organization for standardization (ISO) certification among food manufacturers, as well as many agriculture universities are researching on good agriculture practices, fertilizers and post-harvest techniques (APEDA, 2013a).

The leading international players are entering and trying to set up their presence, and it shows the clear sign of growth of organised retailing sector.Nevertheless, increasing organised sectors are scaring of an unorganised sector like Kirana store, which offers products in lesser price and available on walking distance, hence food traceability is finding an obstacle (USDA, 2014). Still, India is at early stage and needs more struggle and investment to build up cold storage in order to provide facilities for all farm produces. Besides food wastage is also increased due to less available of cold storage, as well as most of the cold storages are manual or multilevel with having less storage capacity (Emerson, 2013).

There is a lack of SPS certification department, it is very important for exporting the farming produces to the foreign countries, which is issued under Ministry of Agriculture, Government of India or district authorized plant protection officers (APEDA, 2013).

About 350 million people reside in rural India and most of them earn through the farming business, majority of farmers are sold out their high-value produce through wholesale markets, both regulated and unregulated. It is always complained by farmers about inadequate market facilities, high marketing fees, long distances to the market, and the dishonesty of traders (World Bank, 2008). Still the many manufacturers could not able to reach or catch the remote market or customer, it is just because of the country's poor infrastructure such as poor road system, 
unconvincing transport systems, power problems, water and major problems in connecting them with stations (World Bank, 2008). As per Agricultural Marketing surveyed by World Bank (2008), observed that Indian market is facing a lot of problems like small roads with less free space within market, limited warehouses and cold storages for farming produces, poor in waste management and pest controls in market, and rat problems as well. For reducing food safety risks can be only improved by investing more to upgrade the market infrastructure and services (World Bank, 2008).

Although India has progressed in information technology (IT) industries, rural areas lagged behind in world of ICT. However, the rate of literacy among rural people is very low with less understanding for the internet-based information, which is available only in English language (Rao, 2009). In India, where 22 languages are officially recognized (Saxena, 2016), and more than $60 \%$ of Indians speak Hindi language and nearly less than $12 \%$ of population in India understand the English (Aula, 2014). 


\section{Chapter 4}

\section{Objectives}

In this $\mathrm{PhD}$ thesis, the research work was divided in four main objectives:

1. To evaluate current food traceability systems in India and assess the level of ICT adoption in rural India. Demonstrating the use information and communication technology in creating effective and efficient traceability systems in India. Studying the access and usages of these systems amongst the rural population who are mainly dependent on agriculture and play a significant role in meeting the food security and food safety concern of the country.

\section{To analyze the shortcomings of ICT initiatives amongst the smallholders' farmers in} India. For this purpose, the author will chose a representative case study, assessing the experience of ICTs use by rural population in relation to the small holders' farmers in the Indian countryside. This objective includes the study of the major constraints faced by farmers in the adoption of new and innovative technologies.

\section{To support local food systems in India and direct sourcing of raw material from farmers} to customer, retailer, food business operator, and exporter in India. Support direct sourcing of raw materials from farm gate to market. In this process, the farmer develops direct contact with the trading actors like manufacturer, exporter, distributor, retailer, and consumer/end user on the basis of quality products. Thus, farmers could directly get connected with trading actors 
and consumers without intermediaries and broker. This could be aided by the use of telecommunications, electronic data interface and other technology advances that make the transfer of information more transparent across supply chain actors.

\section{To increase the net income of smallholder farmers by providing market facility at the} farm gate through web-based traceability portal in India. Food traceability systems are becoming critical for food industry and consumers. However, the increased requirements for documentations and reporting systems are creating hurdles in the adoption of food traceability system in India. The main aim of the traceability portal is to develop a direct link between the farmers and other supply chain actors and help small scale farmers to increase their net profitability by saving their expenses related to information search, transportation cost, marketing cost along with other expenses involved in procuring and selling their products. 


\section{Chapter 5}

\section{Experimental Works and Studies}

In this section, the research works and studies have been carried out to support, refute, and validate a hypothesis in field of adoption of ICT tools among smallholder farmers, along with it has been described web based food traceability portal, which is useful for food operators, logistic providers, and consumer. This portal also helps to save time and cost in building up traceability system for Indian food sector, wherein tracking and tracing information of food products using webserver, and web API technology can be easily obtained.

\subsection{ICT adoption in Small Holders Banana Farmers and Traders in India: A case study on Jalgaon District}

This section 5.1 has submitted to publish in the Spanish Journal of Agricultural Research.

\subsubsection{Introduction}

The agricultural sector plays an important role in the Indian economy. It gives prosperity to millions of farmers, especially small and marginal farmers. It is considered as prime occupation 
of major segment of population (Arjun, 2013; Madhusudhan, 2015). Throughout India, agriculture accounts for around 18.1 per cent of Gross Domestic Product (GDP).

In India, agriculture and its allied sectors are predominantly considered as economic backbone of society and nation. It is the largest livelihood provider, and give support to over 58 per cent of rural households in India (GoI, 2016b; Krishna Reddy \& Ankaiah, 2005; Shiva, 2004). While agriculture GDP in India was registered at USD 244.74 billion in fiscal year 2016, and according to Central Statistics Office (CSO), it is expected to rise above-trend at 4.1 per cent to USD 1,640 billion, as well as it displays a Compound Annual Growth Rates (CAGR) of 6.64 per cent during the period 2007-2016 (India Brand Equity Foundation, 2017). These have led to new opportunities for innovation in agriculture, food and forestry, and brought a number of technological advancements in farming methods. India holds second rank in farm output around USD 367 billion(Bureau, 2016).The incorporation of new developed technologies like ICTs and IoTs are proving beneficial in agricultural activities, and have the potential for development and improving food production in rural India(Jaspreet, 2015; Kameswari, 2011).

In recent years, Indian government has started many IT (information technology) initiatives to make country an unequivocally digital nation by giving an excess of e-governance services across sectors by employing cloud, ICT, mobility, IoT, and analytics. There are many projects that are working under (electronic) e-governance, and (mobile) m-governance including epassport, computerization of land registration project, Gyandoot, Lokvani projects, e-mitra, eseva, Ration Cards or food distribution services, unique identification project (UID) and mobile seva (eGovtIndia, 2014; Kalsi, Kiran, \& Vaidya, 2009; Madon, 2004; M. Shah, 2007).

More than 70 percent population of India lives in rural areas, with a low-level facility like market, health, infrastructure, transportation, and education, as compared to urban(Kesterton, Cleland, Sloggett, \& Ronsmans, 2010; Mitra, Bery, B, \& Krishna, 2010; Ramaswamy, 1998). The National Optical Fibre Network (NOFN) project started under Digital India initiative has opened up new possibility for rural India more significantly for the agriculture sector (DoT, 2015). It prominently focuses on development and growth of every individual in rural areas through Gram Panchayat (Village Council). According to department of telecommunication 
(DoT) report the NOFN project aims to increase the performance of people by giving high-speed broadband connectivity to the large number of gram panchayats (Approx. 250 thousand) in India by the fiscal year 2017-18 (DoT, 2015; Vigneswara Ilavarasan \& Srinivasan, 2014).

Furthermore, technology has made additional positive and significant impact on the growth of agriculture sector. The use of advanced technology is changing and managing the way of farming operations and making it possible for farmers to be more productive. It is helping farmers in number of way, such as sowing seeds in the ground, for plant and harvesting crops, to obtain data from field, and to monitor and implement traceability system and connect to the global market. Besides this, technology has also led to the origin of tractors, vehicles, and farming tools and implements that gives farmers, especially small farmers, broad objectives about increasing the viability of their farms, and handling larger field easily. However, despite a growing technology industry in India, there is still shortage of complete acceptance of technology in local market, as well as farmers' groups, especially smallholder farmers'.

\section{Smallholder Farmers in India: Statistics, Working Conditions and profile}

Small-holders' farmers are defined as those marginal and sub marginal farm holders who own or cultivate less than 2.0 hectare of land. India is one of the top ranked country in smallholder farmers which accounts for 3/4 of total available farms in India. Their average size of operational land holdings is generally between 0.5 ha to 1.4 ha (Chand, Prasanna, \& Singh, 2011; Lowder, Skoet, \& Raney, 2016; Mahendra Dev, 2012b; R. B. Singh, Kumar, \& Woodhead, 2002) and it shares around 44 per cent of total cultivated area(AgCensus, 2011; National Commission for enterprises in the Unorganised Sector, 2008), as shown in the table 5.1 below; this disparity in the distribution pattern of agricultural land holding forms the main feature of all developing countries and it leads to differences in income levels among the farming community (Pal, 1992).

Small holdings agriculture plays a significant role in increasing agriculture growth, food security, and reducing poverty (Lipton, 2004). In terms of production, both small and marginal farmers contribute to large amount of production of high value crops where fruits contribute 55 per cent, and vegetable 70 percent (Birthal, And, \& 2011, 2011) from less than half of total cultivated area 
According to data report by National Sample Survey (NSS), the productivity from small land holdings farmers is better as compared to medium and large farmers (NSS, 2003).

However, despite this improved productivity, many issues and challenges are still alive, which includes low level of formal education and skills, environmental problem, water shortage, diversification, impact of climate change (Thapa \& Gaiha, 2014), and increasing share of labour (55 per cent) with lesser share of farm mechanization (40 per cent). Beside this, today's Indian small holding farmers are highly dependent upon the urban market and natural environment, where activities are continuously changing (Priya \& Mathiyalagan, 2012).

In addition, rising unpredictable rainfall patterns and declining rainfall due to global climate change is also emerging as major concern for food security in India (Thapa \& Gaiha, 2014). These issues can be addressed with the help of technological and digital innovations. IT penetration in rural India can give boost to the agricultural sector and help India emerge as a global leader. It can develop as a strategic tool for marginal and small farmers to raise agricultural and increase their incomes through diversification and high value agriculture. It is to this that we now turn our attention. 
Table 5.1: Farming profile in India and distribution of holdings

\begin{tabular}{|c|c|c|c|c|c|c|}
\hline \multirow{2}{*}{ Year } & \multicolumn{3}{|c|}{$\begin{array}{l}\text { Percentage of number of } \\
\text { operational holdings to total }\end{array}$} & \multicolumn{3}{|c|}{ Percentage of area operated to total } \\
\hline & $\begin{array}{l}\text { Marginal } \\
\text { farmers }\end{array}$ & $\begin{array}{l}\text { Small } \\
\text { farmers }\end{array}$ & Total & $\begin{array}{l}\text { Marginal } \\
\text { farmers }\end{array}$ & Small farmers & Total \\
\hline 1981-82 & 45.8 & 22.4 & 68.2 & 11.5 & 16.6 & 28.1 \\
\hline 1991-92 & 56.0 & 19.3 & 75.3 & 15.6 & 18.7 & 34.3 \\
\hline $2002-03$ & 62.8 & 17.8 & 80.6 & 22.6 & 20.9 & 43.5 \\
\hline 2010-11 & 67.10 & 17.91 & 85.01 & 22.50 & 22.08 & 44.58 \\
\hline
\end{tabular}

*Marginal farmer: below 1.00 ha, Small: 1.00 to 2.00 ha.

Source: Central Statistical Organization, Government of India, (AgCensus, 2011).

\section{E-Agriculture in India: Advantages and Issues}

Indian agriculture sector faces key challenges due to several unfavorable conditions like rising import, water scarcity, lack of implementation, insufficient land reforms, and defective land management (K. M. Singh, Kumar, \& Singh, 2015; The World Bank, 2012). As stated by Arun Jaitley, the Indian finance minister, Indian agriculture sector has stuck into the network of challenges that could only be silenced by adaption of latest IT Digital technology. This would prove beneficial to raise productivity with the help of high yielding and resistant variety of seeds, water utilization, reduce wastages, and improvement in marketing of farm produces, which 
would help to get increased price benefits to farmers by updating market information(GoI, 2016a).

\section{Advantages of e-agriculture in India}

Besides, e-agriculture is essential to raise the farming productivity, and profitability of thousands of small and marginal farmers. In addition, mobile subscribers and handsets are increased in large number in rural areas, and it is clearly indicated that technology has successfully entered in remote area and is providing up-to-date information to farmers on subjects such as packages, practices, market, weather forecasting, input supplies, and credit availability as early as possible. New technology is easily accessible by any age group people anytime in the day for any concern and from any part of the state. Majority of Indian remote farmers are able to purchase these systems including television, Internet connectivity, telephone, and mobile (networks offering good voice connectivity) that are helpful to provide latest information and run digital technology efficiently.

\section{Major issues of e-agriculture in India}

ICT is utilized for providing accurate, timely and relevant information to farmers, thereby providing an environment for improved agricultural productivity. However, all the ICT initiatives are not able to reach all group of farmers including small, medium, and large due to poor economic conditions and social constraints. On the other hand, major factors for this disparity are illiteracy, language barrier, and substantial low level of investment in new infrastructure for both hardware and software, which results to disapprove the upcoming technology. Besides, insufficient power supply in rural areas, poor ICT infrastructure, and poor advisory services, all these factors collectively become the prime reason of hindrances. Moreover, increase in inflation has also adversely impacted over mobile technology in rural areas because of low profiled group of farmers, however high cost of mobile recharge (voice and text message) and language what is mainly communicated or used (which is English mostly available in the mobile technology for mobile handsets and text messages), but to hold responsible these elements that generates more barriers for rural farmers in India. 
Thus, to address the framers' unmet needs, there is a strong need to develop the market-led business model that would increase the productivity, market orientation, value addition, and margin as well as set up more ICT kiosks in every village with internet access.

\section{Overview of Indian Banana Production}

Banana is one of the most lovable foods across the globe due to its low price and high nutritive value. This has led to steady increase in world production of banana over the years. Moreover, banana grows in more than about 100 countries under temperate, subtropical and tropical conditions. Total annual world production is estimated at 114.13 million tons of banana fruits with an area of 5393.811 thousand ha (FAOSTAT, 2016).

According to data report by National Horticulture Board (NHB), Jalgaon is the single highest banana producer district in western India, and its bananas are wholly produced by independent growers, which are further supplied into "Fair-trade markets" in order to get more exposure, and these Fair-trade markets are organized by cooperatives or producer or local grower associations which provide the link with the market and offer different levels of support to their members.

In addition, India is by far the largest producer in the world, with an area of 802.6 thousand ha, and an annual production of 29.7 million tons of banana. This represents nearly 30 per cent of the total world production. In India, the states of Tamil Nadu, and Maharashtra, are the largest producers of banana, with about 201.04 thousand hectares of this crop (NHB, 2015). Other leading banana producer countries are Brazil, Ecuador, China, Philippines, Indonesia, Costa Rica, Mexico, Thailand and Colombia. 


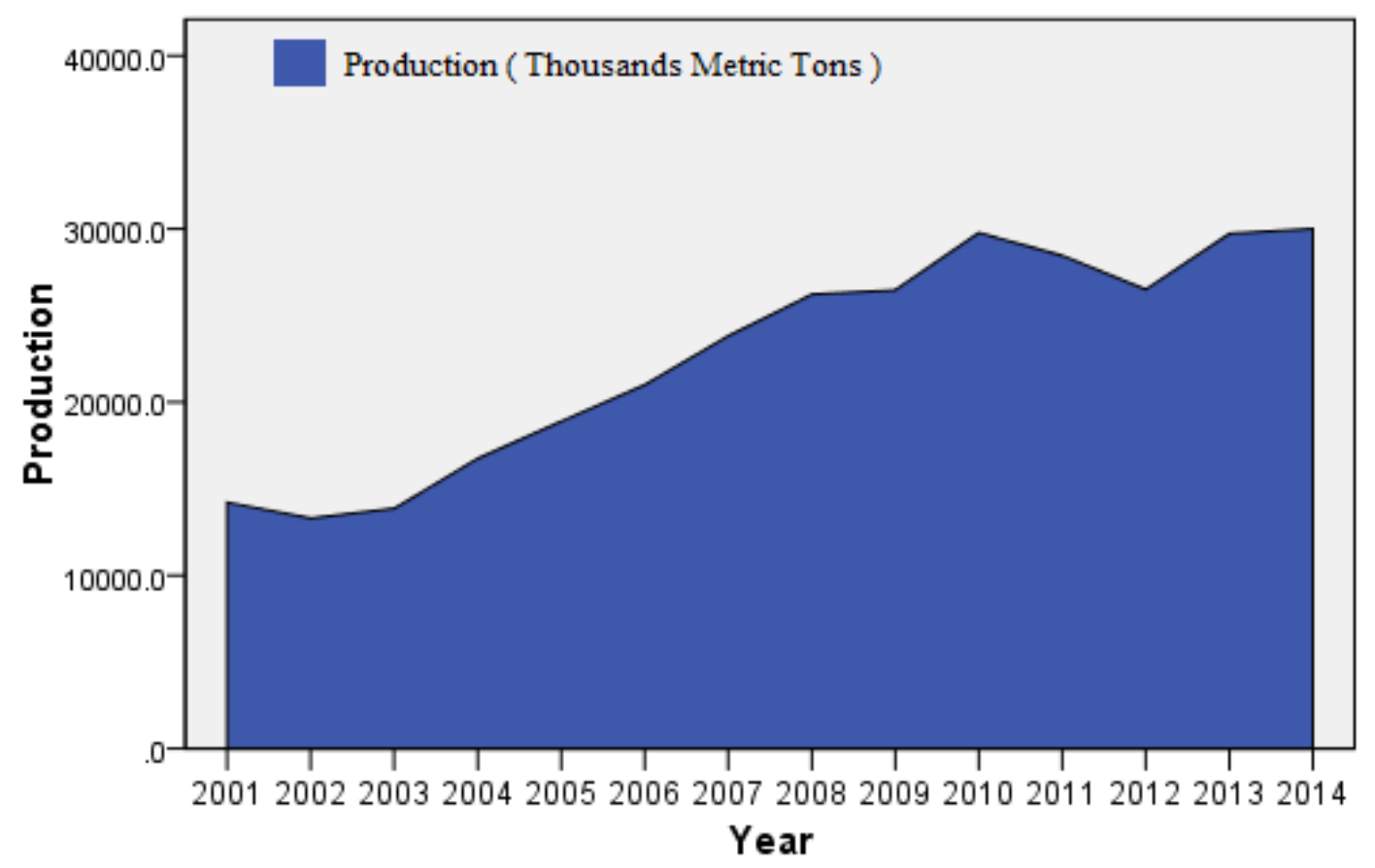

Figure 5.1: Production of Banana in India from 2001 to 2014.

Source: National Horticulture Board, 2015

Recent evidence suggests that the Indian banana crop has an increasing trend in production and cultivation area at both country and state level, while slight movement is observed at district level (NHB, 2015). According to data report by FAO (2016), the banana production rate has increased during 2001 to 2014 almost by 110 per cent, which is 29724.6 thousand metric tons in the year 2014, and 14209.4 thousand metric tons in the last year 2001 (FAOSTAT, 2016). However, the above figure 5.1 shows that there has been a marked increase in the production of banana in India, hence the rate of production is expected to increase after 2020. 


\section{Description of Study Area}

Jalgaon District is located in western India, to the north of the Maharashtra state, which itself is situated on the northern Deccan Plateau, as well as it is positioned within the productive, and irrigated agricultural region.

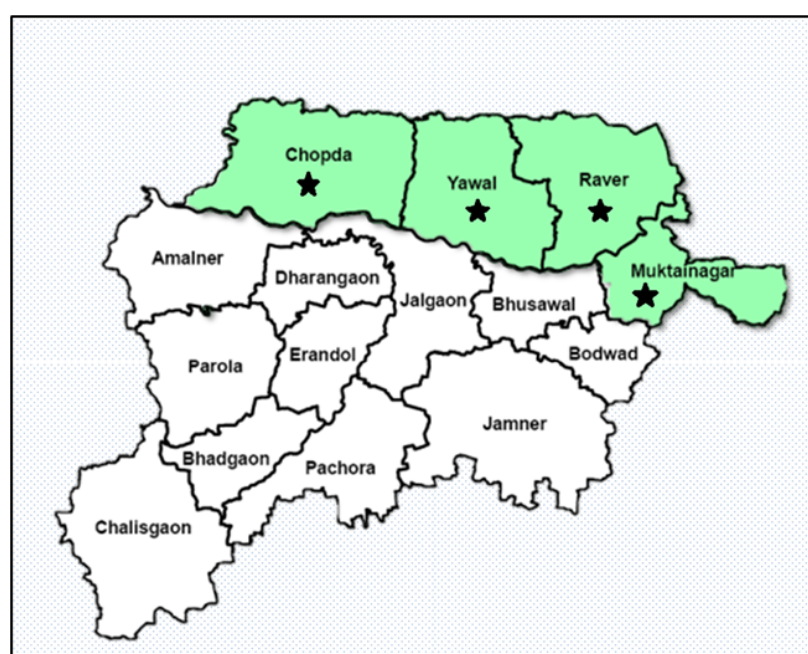

Tehsil of Jalgaon District

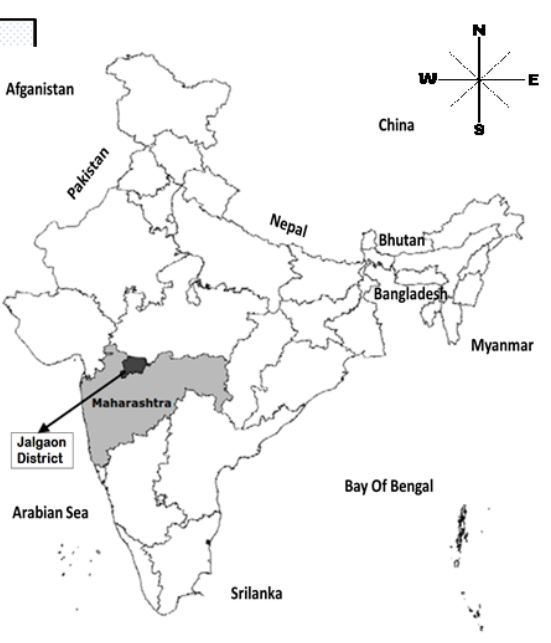

India Outline Map

Figure 5.2: Tehsil of Jalgaon District

According to national horticulture board and comprehensive District Agriculture Plan (C-DAP) by Maha Agri, Jalgaon district is a single district in the India and produces more than 3 million tons of banana in 46.07 thousand ha area. Annually it produces near about 16 per cent of India's bananas, which represents approximately 3 per cent of world banana production (see figure 5.3 below). According to Mahabanana, nearly 66 per cent of Maharashtra's land under banana crop comes from only Jalgaon district, where major banana producing areas are Muktainagar, Raver, Yawal, and Chopda (see above figure 5.2). All these are Tehsil area, it is a sub division of district in India or low-level administrative division of India(CensusIndia, 2016), and major contributors in the Jalgaon district (MahaAgri, 2016; NHB, 2015). 


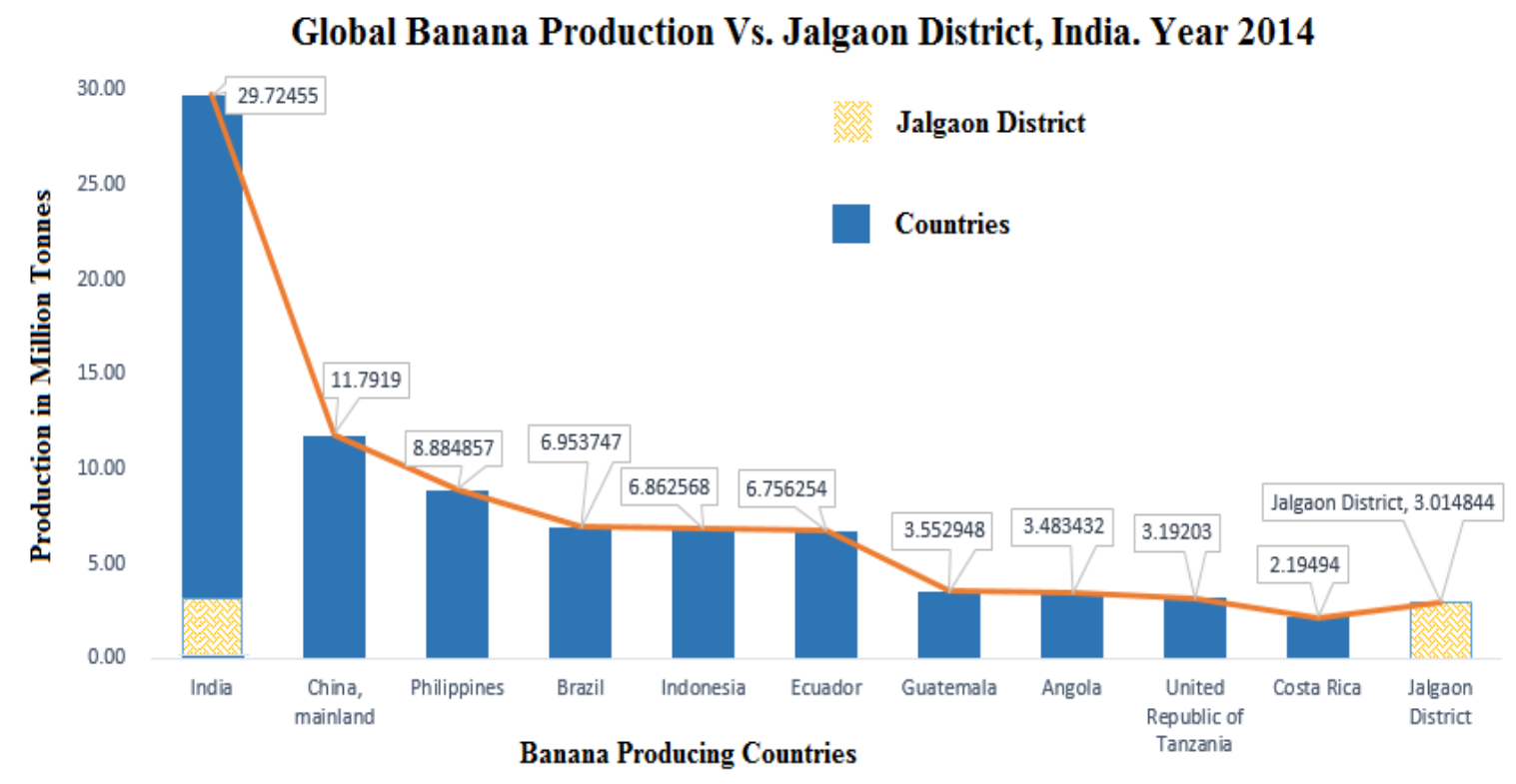

Figure 5.3: Graphical Representation of Global Banana Production Vs. Jalgaon District, India. Year 2014

Source: (FAOSTAT, 2016; MahaAgri, 2016; NHB, 2015)

The present study was conducted in month of July 2016 and January 2017 in the banana production region of Jalgaon district of North Maharashtra in India. In this area, nearly 80 per cent of the population are farmers, and 50 per cent of them are actively involved in banana cultivation process. However, this district was purposively selected because it has occupied more area under banana cultivation rather than any other district in India, as well as its highest banana producing district in the world as shown in above figure 5.3. Thus, this area was selected due to four reasons:

1. Majority of the farmers are involved in banana cultivation 
2. They have experience of working with well organised government sector, as well as various private sectors

3. Close proximity to the researcher, private companies and supply chain

4. It is the single largest banana producing district across India, as well as world; if it were a country, it would be included in the world top ten banana producing countries (see figure $5.3)$.

\subsubsection{Material and Methods}

The adoption of ICT is taken from a field survey of small land holding banana farmers and local trader and street sellers. Four tehsils (sub-district) and villages were selected from Jalgaon district, which include Muktainagar, Raver, Yawal, and Chopda. In each village, a number of five smallholder farmers were randomly selected. In total 100 farmers as respondent were selected for interview. In addition, five rural markets, and one district level market within the selected tehsil area were visited and 15 traders were identified and interviewed. It was a face-toface survey containing two type of questionnaire sets and selected list of ICTs tools which were categorized into basic, medium, and advanced level (Appendix A).

\section{Sources of Data Collection and Analysis}

The instrument consisted 6 questions for smallholder banana farmers, and 9 questions for banana with traders, all questions were structured into regional local language that was Marathi. Simultaneously, personal data was collected from banana farmers, and traders, which include their socioeconomic characteristics like gender, age, marital status, ownership of farm, education, income. Farming information such as number of experiences in farming field, ways of cultivating method like traditional or modern, and cropping method like tissue culture or nontissue culture, and proximity with markets like distance, and contacts with traders, while conducting survey respondents were asked to tick mark over selected tools (Appendix A) which they were currently using for day to day work activities related to farming and trading. Some of them tick marked over single tool, and other ticked marked over multiple ICT tools. Further, as 
per selection preference of ICT tools and marking by respondents they were asked to fill in the proforma for farmers (Appendix B) and other proforma for traders (Appendix C).

\section{Empirical Studies}

The key informants of this research were the local small land holding banana farmers and local banana traders from Jalgaon district. The responses elicited from the respondents were quantified by Likert's five-point rating while for the other analysis, respondents were asked to indicate the constraints faced by them in adoption of the ICTs tools that were quantified by using Garrett Ranking Method.

Furthermore, the data analysis was performed using descriptive statistics specifically measures of mean and standard deviation, percentage for farmers, and traders. And the statistical methods used in this research included R squared, statistic model fitness, Summary of multiple linear regression and Pearson correlation, using the Statistical Package for the Social Sciences (SPSS) 24.

\section{Likert's Five Point Rating Scale}

The Likert's rating scale is a psychometric scale commonly used in research that employs questionnaires. Likert-type or frequency scales use fixed choice response formats and are designed to measure attitudes or opinions (Bowling, 2002; Grove, Burns, \& Hegstad, 1997). This type of scale offers a range of answer options in the survey questions. In this study, a typical five-level Likert item was used, with the following items:

1. Strongly Agree

2. Agree

3. Undecided (neutral)

4. Disagree

5. Strongly Disagree

According to this method, two questionnaires were prepared. One for the farmers (Appendix B) and the other one for local trader and street sellers (Appendix C). 


\section{Garrett's Ranking Method}

The Garrett Ranking Method was used in this study to find out the constraint to ICT adoption in smallholding banana farmers in area of survey field. Based on the opinion of the respondents, the rank was calculated, whereas these respondents were requested to fill in Performa containing the number of factors related to constraint in adopting the ICT tools (Appendix D).

With the help of Garrett's method, the percent position is calculated by using the following Garrett's formula for converting ranks into percent (see equation 1)

Percent position $=100 \cdot\left(\mathrm{R}_{\mathrm{ij}}-0.5\right) / \mathrm{N}_{\mathrm{j}} \quad$ (equation 1)

Where,

$$
\begin{aligned}
& \mathrm{R}_{\mathrm{ij}}=\text { rank given for } \mathrm{i}^{\text {th }} \text { constraint by } \mathrm{j}^{\text {th }} \text { respondents; } \\
& \mathrm{N}_{\mathrm{j}}=\text { number of constraint ranked by } \mathrm{j}^{\text {th }} \text { respondents }
\end{aligned}
$$

With the help of Garrett's Ranking Conversion Table which is given by Garrett and Woodworth (1969), the percent position estimated was converted into Garrett scores. Then for each factor, the scores of each individual respondent are added together and divided by the total number of the respondents for whom scores need to be added. These mean scores for all the constraints are arranged in descending order; the constraints are then ranked accordingly.

\section{Regression model}

In this regression analysis using SPSS 24, the observed variables are ICT usage, ownership of ICT tools and education level, these all would be collectively proved that which variable is prominently supporting to the Adoption of ICTs technology in the selected research area. In particular, the p-value is labeled as "Sig." in the SPSS output ("Sig." stands for significance level), its less than $0.05 \quad(<0.05)$ are often reported as "statistically significant", so the variable is significant and if its greater than $0.05(\geq 0.05)$ the variable is not supporting or non-significant for adopting the ICTs at 95\% confidence level, as well as t test was used to verify statistical significance to independent variables. The coefficient of determination 
$\left(\mathrm{R}^{2}\right)$ between 0 to 1 , it indicates that the value towards 1 a better explanation of variance is being provided by model, however when number of samples are increased, greater the coefficient of determination, hence adjusted $\mathrm{R}^{2}$ is usually used in multiple linear regression model instead of $\mathrm{R}^{2}$.

The formula used for linear regression model is followed;

$\mathrm{Y}=\mathrm{B}_{\mathrm{o}}+\mathrm{B}_{1} \cdot \mathrm{X}_{1}+\mathrm{B}_{2} \cdot \mathrm{X}_{2}+\mathrm{B}_{3} \cdot \mathrm{X}_{3}+\mathrm{e} \quad$ (equation 2)

Where;

$\mathrm{Y}=$ Adoption ICT Tools, $\mathrm{B}_{0}=$ Constant, $\mathrm{e}=$ error term

$\mathrm{X}_{1}=$ ICT usage $\mathrm{X}_{2}=$ Ownership ICT; $\mathrm{X}_{3}=$ Education level 


\subsubsection{Results and Discussions}

The focus of study is to analyze the predictor's variables that define the chances of adoption of ICT tools for the betterment of food traceability system to enhance the future production and generating the high-tech secured market for smallholder banana farmers and traders in the selected research area of Jalgaon district, Maharashtra state, India. The empirical evidence attained from statistical analysis using Likert's rating scale, Garrett's ranking method and Statistical Package for the Social Sciences SPSS 24, are presented and discussed below.

\section{Results from Likert's Five Point Rating Scale}

Summary information for the Likert items can be seen in below tables 5.2 and 5.3, which presents percentage for ICT Adoption in smallholding banana farmers, and local trader and sellers.

Table 5.2: Percentage for ICT Adoption in smallholding banana farmers

\begin{tabular}{|l|l|l|l|l|l|}
\hline \multicolumn{1}{|c|}{ Rating } & $\begin{array}{l}\text { Strongly } \\
\text { Agree }\end{array}$ & Agree & Undecided & Disagree & $\begin{array}{l}\text { Strongly } \\
\text { Disagree }\end{array}$ \\
\hline Questions & & & & & \\
\hline $\begin{array}{l}\text { Frequently use of } \\
\text { selected tool and getting } \\
\text { useful information from } \\
\text { that tool? }\end{array}$ & $31.5 \%$ & $20.7 \%$ & $18.5 \%$ & $25.0 \%$ & $4.3 \%$ \\
\hline Tool is very easy to use & $23.9 \%$ & $12.0 \%$ & $22.8 \%$ & $27.2 \%$ & $14.1 \%$ \\
\hline $\begin{array}{l}\text { Comfortable using in } \\
\text { your own language rather } \\
\text { than English? }\end{array}$ & $39.1 \%$ & $15.2 \%$ & $17.4 \%$ & $16.3 \%$ & $12.0 \%$ \\
\hline $\begin{array}{l}\text { An easy access to } \\
\text { learning the technique? }\end{array}$ & $19.6 \%$ & $25 \%$ & $20.7 \%$ & $13.0 \%$ & $21.7 \%$ \\
\hline $\begin{array}{l}\text { An information provided } \\
\text { by tool is very helpful }\end{array}$ & $34.8 \%$ & $29.3 \%$ & $14.1 \%$ & $9.8 \%$ & $12.0 \%$ \\
\hline $\begin{array}{l}\text { After using the system do } \\
\text { you feel it can be really } \\
\text { useful to increase } \\
\text { production and supply } \\
\text { chain? }\end{array}$ & $33.7 \%$ & $23.9 \%$ & $10.9 \%$ & $22.8 \%$ & $8.7 \%$ \\
\hline
\end{tabular}


PhD Thesis

Keshav Prakash Dandage

Experimental Works and Studies

Table 5.3: Percentage for ICT Adoption in Banana Traders

\begin{tabular}{|c|c|c|c|c|c|}
\hline Rating & $\begin{array}{l}\text { Strongly } \\
\text { Agree }\end{array}$ & Agree & Undecided & Disagree & $\begin{array}{l}\text { Strongly } \\
\text { Disagree }\end{array}$ \\
\hline \multicolumn{6}{|l|}{ Questions } \\
\hline $\begin{array}{l}\text { Frequently use of } \\
\text { selected tool and getting } \\
\text { useful information from } \\
\text { that tool? }\end{array}$ & $26.7 \%$ & $46.7 \%$ & $13.3 \%$ & $6.7 \%$ & $6.7 \%$ \\
\hline Tool is very easy to use & $20.0 \%$ & $33.3 \%$ & $26.7 \%$ & $6.7 \%$ & $13.3 \%$ \\
\hline $\begin{array}{l}\text { Comfortable using in } \\
\text { your own language } \\
\text { rather than English? }\end{array}$ & $53.3 \%$ & $26.7 \%$ & $6.7 \%$ & $6.7 \%$ & $6.7 \%$ \\
\hline $\begin{array}{l}\text { An easy access to } \\
\text { learning the technique? }\end{array}$ & $40.0 \%$ & $20.0 \%$ & $26.7 \%$ & $6.7 \%$ & $6.7 \%$ \\
\hline $\begin{array}{l}\text { An information } \\
\text { provided by tool is very } \\
\text { helpful }\end{array}$ & $40.0 \%$ & $33.3 \%$ & $6.7 \%$ & $13.3 \%$ & $6.7 \%$ \\
\hline $\begin{array}{l}\text { Helping in increasing } \\
\text { and controlling over } \\
\text { production }\end{array}$ & $26.7 \%$ & $40.0 \%$ & $13.3 \%$ & $6.7 \%$ & $13.3 \%$ \\
\hline $\begin{array}{l}\text { Helping in increasing } \\
\text { business and trading } \\
\text { across market }\end{array}$ & $26.7 \%$ & $33.3 \%$ & $13.3 \%$ & $20.0 \%$ & $6.7 \%$ \\
\hline $\begin{array}{l}\text { Helpful in controlling } \\
\text { over batches and lots }\end{array}$ & $66.7 \%$ & $33.3 \%$ & 0 & 0 & 0 \\
\hline $\begin{array}{l}\text { Getting complicated } \\
\text { result with help of this } \\
\text { tool }\end{array}$ & $33.3 \%$ & 0 & $66.7 \%$ & 0 & 0 \\
\hline
\end{tabular}


According to key informant responses as shown in table 5.2 that there are many banana farmers in Jalgaon District, India, are found that ICTs tools are really helpful for their progress. The findings showed that $33.7 \%$ farmers as cited in table 5.2, agreed that the use of ICTs is useful to increase production and supply chain. This means that with the help of new technology the production and marketing would increase and also the use of ICT amongst farmers to a great extent. But if focused on the medium of language for tools then as cited by $39.1 \%$ by farmers as shown in table 5.2 and $53.3 \%$ by traders as shown in table 5.3 preferred their regional language. Hence in both categories language is their main issue due to which both farmers and traders are not comfortable with adoption of ICTs in their farming, business and trading.

Most of the smallholding banana farmers, and traders have only obtained the basic education and there are some who have neither attended any school, nor any farmers training or basic knowledge of ICTs. By all means they are totally unaware about the new modern technology, while in few cases, both farmers and traders have just attended post-secondary school and have achieved quiet higher education and have a better understanding of ICTs.

\section{Results from the application of Garrett's ranking method:}

The summary information can be seen in tables 5.4 and 5.5, where factors are indicated by F1 Poor access of Internet in field, F2_ Poor Quality Of ICTs tools, F3_ Lack of Updating of Technology, F4_ Lack of Training to farmers from Agriculture Extension Officer, F5 Inadequate electricity supply, F6_ Less understanding of English language, and Education , F7 Absence of Government Policies towards ICTs tools for Smallholder farmer , F8_ High cost of ICTs tools, and for this total 100 respondents are allowed to rank their preferences from 1, 2, 3, $4,5,6,7,8$, where strong positive preference is indicated by 1 to lowering down up to 8 as shown in below table 5.5, on which they rely on. 
Table 5.4: Constraint influencing factors for banana farmers

\begin{tabular}{|c|c|c|c|c|c|c|c|c|c|}
\hline$\frac{\text { Rank }}{\stackrel{\text { Factors }}{\longrightarrow}}$ & 1 & 2 & 3 & 4 & 5 & 6 & 7 & 8 & Total \\
\hline F1 & 43 & 5 & 6 & 7 & 9 & 13 & 9 & 8 & 100 \\
\hline F2 & 7 & 9 & 8 & 15 & 17 & 13 & 17 & 14 & 100 \\
\hline F3 & 7 & 7 & 11 & 14 & 21 & 14 & 11 & 15 & 100 \\
\hline F4 & 9 & 20 & 15 & 11 & 10 & 11 & 12 & 12 & 100 \\
\hline F5 & 21 & 15 & 16 & 6 & 12 & 8 & 9 & 13 & 100 \\
\hline F6 & 4 & 19 & 14 & 16 & 7 & 15 & 12 & 13 & 100 \\
\hline F7 & 5 & 14 & 13 & 17 & 11 & 16 & 12 & 12 & 100 \\
\hline F8 & 4 & 11 & 17 & 14 & 13 & 10 & 18 & 13 & 100 \\
\hline & 100 & 100 & 100 & 100 & 100 & 100 & 100 & 100 & \\
\hline
\end{tabular}

Table 5.5: Garrett's percent Position and Garrett's Score

\begin{tabular}{|l|l|l|l|}
\hline Rank & $\mathbf{1 0 0} *\left(\mathbf{R}_{\mathbf{i j}}-\mathbf{0 . 5}\right) / \mathbf{N}_{\mathbf{j}}$ & $\begin{array}{l}\text { Percent } \\
\text { position }\end{array}$ & Garrett Score \\
\hline $\mathbf{1}$ & $100(1-0.5) / 8$ & 6.25 & 80 \\
\hline $\mathbf{2}$ & $100(2-0.5) / 8$ & 18.75 & 68 \\
\hline $\mathbf{3}$ & $100(3-0.5) / 8$ & 31.25 & 59 \\
\hline $\mathbf{4}$ & $100(4-0.5) / 8$ & 43.75 & 53 \\
\hline $\mathbf{5}$ & $100(5-0.5) / 8$ & 56.25 & 47 \\
\hline $\mathbf{6}$ & $100(60.5) / 8$ & 68.75 & 40 \\
\hline $\mathbf{7}$ & $100(7-0.5) / 8$ & 81.25 & 32 \\
\hline $\mathbf{8}$ & $100(8-0.5) / 8$ & 93.75 & 20 \\
\hline
\end{tabular}




\section{Constraints to ICT adoption in small land holding banana farmers using Garrett's ranking method}

For calculating the total score for each rank was multiplied by Garrett score with the given value as shown in above table 5.6, then each factor summed up all the values which was given by respondents to factors, then calculate the average score which is very essential to rank up factors to finding out particular constraints. Each total score divided by total number of respondents, equals to 100 respondents. For factor F1 to F8 the average scores calculated in this manner, later on obtained average score is ranked as the higher average score is given first rank and so on as shown in table below table 5.6.

Table 5.6: Calculated Garrett Score

\begin{tabular}{|l|l|l|l|l|l|l|l|l|l|l|c|}
\hline$\underset{2}{\text { Rank }} \rightarrow$ & $\mathbf{1}$ & $\mathbf{2}$ & $\mathbf{3}$ & $\mathbf{4}$ & $\mathbf{5}$ & $\mathbf{6}$ & $\mathbf{7}$ & $\mathbf{8}$ & Total & AS & Rank \\
\hline F1 & & & & & & & & & & & \\
\hline F2 & 3440 & 340 & 354 & 371 & 423 & 520 & 288 & 160 & $\mathbf{5 8 9 6}$ & 58.96 & $\mathbf{1}$ \\
\hline F3 & 560 & 612 & 472 & 795 & 799 & 520 & 544 & 280 & $\mathbf{4 5 8 2}$ & 45.82 & $\mathbf{8}$ \\
\hline F4 & 560 & 476 & 649 & 742 & 987 & 560 & 352 & 300 & $\mathbf{4 6 2 6}$ & 46.26 & $\mathbf{7}$ \\
\hline F5 & 720 & 1360 & 885 & 583 & 470 & 440 & 384 & 240 & $\mathbf{5 0 8 2}$ & 50.82 & $\mathbf{3}$ \\
\hline F6 & 1680 & 1020 & 944 & 318 & 564 & 320 & 288 & 260 & $\mathbf{5 3 9 4}$ & 53.94 & $\mathbf{2}$ \\
\hline F7 & 420 & 1292 & 826 & 848 & 329 & 600 & 384 & 260 & $\mathbf{4 8 5 9}$ & 48.59 & $\mathbf{4}$ \\
\hline F8 & 320 & 748 & 1003 & 742 & 611 & 400 & 576 & 260 & $\mathbf{4 6 6 0}$ & 46.6 & $\mathbf{6}$ \\
\hline
\end{tabular}

$\mathrm{AS}=$ Average Score 


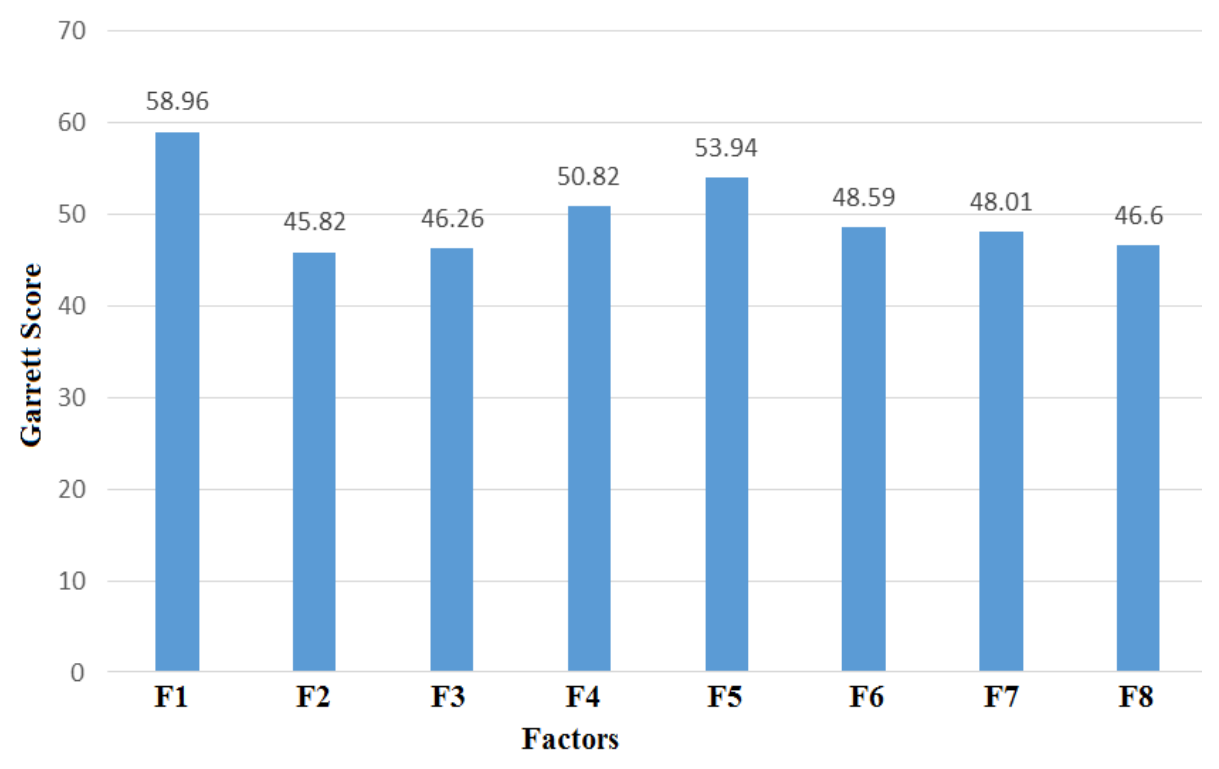

Figure 5.4: Constraint Influencing Factors in adopting ICT

The result from table 5.6 and figure 5.4 indicated the number of constrains faced by smallholding banana farmers in the selected study area, whereas with the help of Garrett ranking method, it is clearly known the exact barrier which has stopped the progress of smallholder banana farmers, and that factors are F1_Poor access of Internet in field (58.96), F5_ Inadequate electricity supply (53.94), and F4_Lack of Training to farmers from Agriculture Extension Officer (50.82). These are the major responsible factors that have created the constraints in adopting the new ICTs technology for increasing production and marketing value of banana in district Jalgaon, India.

\section{ICT Adoption In small holding Banana farmers and Traders}

Tables 5.7 and 5.8 show the summary of adoption of ICT tools for production and marketing in small holding banana farmers, and traders the mean (M) and standard deviation (SD) were used to show the highest ranked and lowest ranked adoption.

The results from table 5.7 shows that the most cited ICTs adoption in farmers. Farmers believed that the ICTs tools are helpful to get necessary information $(\mathrm{M}=3.65 ; \mathrm{SD}=1.36)$, but at other 
hand farmers are not comfortable using in English language and gives their preference to the native language $(\mathrm{M}=3.53 ; \mathrm{SD}=1.45)$. Most farmers agreed that after using the new system the rate of production and supply chain might increase $(\mathrm{M}=3.51 ; \mathrm{SD}=1.39)$. The lowest ranked for tools are easy to use $(\mathrm{M}=3.04 ; \mathrm{SD}=1.39)$ followed by easy access to learning the new techniques related to banana farming $(\mathrm{M}=3.08 ; \mathrm{SD}=1.43)$.

Table 5.7: Adoption of ICT tools for Farmers

\begin{tabular}{|c|c|c|c|c|}
\hline \multicolumn{5}{|l|}{ Statistics } \\
\hline Questions & Mean & $\begin{array}{l}\text { Standard } \\
\text { Error of } \\
\text { Mean }\end{array}$ & Median & $\begin{array}{l}\text { Standard } \\
\text { Deviation }\end{array}$ \\
\hline $\begin{array}{l}\text { Do you frequently use the above } \\
\text { selected tool and getting useful } \\
\text { information from that tool? }\end{array}$ & 3.50 & 0.13 & 4.00 & 1.29 \\
\hline $\begin{array}{l}\text { Do you think the tool is very easy to } \\
\text { use? }\end{array}$ & 3.04 & 0.14 & 3.00 & 1.39 \\
\hline $\begin{array}{l}\text { Does it feel more comfortable using } \\
\text { in your own language rather than } \\
\text { English? }\end{array}$ & 3.53 & 0.15 & 4.00 & 1.45 \\
\hline $\begin{array}{l}\text { Do you think it was an easy access } \\
\text { to learning the technique? }\end{array}$ & 3.08 & 0.15 & 3.00 & 1.43 \\
\hline $\begin{array}{l}\text { Do you think the information } \\
\text { provided by tool is very helpful }\end{array}$ & 3.65 & 0.14 & 4.00 & 1.36 \\
\hline $\begin{array}{l}\text { After using the system do you feel it } \\
\text { can be really useful to increase } \\
\text { production and supply chain }\end{array}$ & 3.51 & 0.14 & 4.00 & 1.39 \\
\hline
\end{tabular}


Table 5.8: Adoption of ICT tools for Traders

\begin{tabular}{|c|c|c|c|c|}
\hline \multicolumn{5}{|l|}{ Statistics } \\
\hline Questions & Mean & $\begin{array}{l}\text { Standard } \\
\text { Error of } \\
\text { Mean }\end{array}$ & $\begin{array}{l}\text { Media } \\
\text { n }\end{array}$ & $\begin{array}{l}\text { Standard } \\
\text { Deviation }\end{array}$ \\
\hline $\begin{array}{l}\text { Frequently use of selected tool and getting } \\
\text { useful information from that tool? }\end{array}$ & 3.80 & 0.30 & 4.00 & 1.15 \\
\hline Tool is very easy to use & 3.40 & 0.33 & 4.00 & 1.30 \\
\hline $\begin{array}{l}\text { Comfortable using in your own language } \\
\text { rather than English? }\end{array}$ & 4.13 & 0.32 & 5.00 & 1.25 \\
\hline An easy access to learning the technique? & 3.80 & 0.33 & 4.00 & 1.26 \\
\hline $\begin{array}{l}\text { An information provided by tool is very } \\
\text { helpful }\end{array}$ & 3.87 & 0.34 & 4.00 & 1.30 \\
\hline $\begin{array}{l}\text { Helping in increasing and controlling over } \\
\text { production }\end{array}$ & 3.60 & 0.35 & 4.00 & 1.35 \\
\hline $\begin{array}{l}\text { Helping in increasing business and trading } \\
\text { across market }\end{array}$ & 3.53 & 0.37 & 4.00 & 1.30 \\
\hline Helpful in controlling over batches and lots & 4.67 & 0.33 & 5.00 & 0.58 \\
\hline $\begin{array}{l}\text { Getting complicated result with help of this } \\
\text { tool }\end{array}$ & 3.67 & 0.67 & 3.00 & 1.15 \\
\hline
\end{tabular}

The results from above table 5.8 shows that the most cited ICTs adoption in traders. Traders believed that the ICTs tools are helpful to get control over batches and lots $(\mathrm{M}=4.67 ; \mathrm{SD}=0.58)$, but on other hand local traders are also not comfortable using in English language and gives their preference to the native language $(M=4.13 ; \mathrm{SD}=1.25)$. Most traders admitted that the information provided from the ICTs tools are really usable $(\mathrm{M}=3.87 ; \mathrm{SD}=1.30)$. The lowest ranked for tools 
are easy to use $(\mathrm{M}=3.40 ; \mathrm{SD}=1.30)$ followed by helping in increasing business and trading across market $(\mathrm{M}=3.53 ; \mathrm{SD}=1.30)$.

\section{Result from the application of regression model}

In the following table 5.9, regression coefficient was estimated by considering adoption ICTs tools as dependent variable, and independent variables are ICT usage, ownership of ICT, and education level.

The coefficient of determination $\left(\mathrm{R}^{2}\right)$ was 0.635 , as shown in below table 5.9, which explained about 63.5 per cent of the variance. In particular, the adjusted coefficient of determination used for explanation of multiple linear regression model was 0.623 . The difference between the coefficient of determination $\left(\mathrm{R}^{2}=0.635\right)$ and the adjusted coefficient of determination (adjusted $\left.\mathrm{R}^{2}=0.623\right)$ was within 10 per cent, and the model is evaluated to provide a good statistical explanation and to be a stable model that is not significantly affected by individual variables.

To detect the autocorrelation in the residuals from the regression analysis (independence of residuals), the Durbin-Watson statistic was used. Where value of 2 means there is no correlation between residuals, showing standard distribution. In addition, values approaching 0 indicate a positive autocorrelation and values toward 4 indicate a negative autocorrelation. If the values of Durbin- Watson statistic are closer to 0 or 4 , the errors are correlated, which means the model is inappropriate. As indicated in below table 5.10, the value of the Durbin-Watson statistic is 1.063, which is close to 2 so it can be accepted that there is independence of errors (residuals).

Table 5.9: Summary of statistic model fitness

\begin{tabular}{|c|c|c|c|c|c|}
\hline Model & $\mathbf{R}$ & $\mathbf{R}^{2}$ & $\begin{array}{c}\text { Adjusted R } \\
\text { Square }\end{array}$ & $\begin{array}{c}\text { Standard Error } \\
\text { of the Estimate }\end{array}$ & $\begin{array}{c}\text { Durbin- } \\
\text { Watson }\end{array}$ \\
\hline 1 & .797 & .635 & .623 & .247 & 1.063 \\
\hline
\end{tabular}


The impact of independent variables can be estimated by comparing absolute values of standardized coefficient (Beta value). Of the variables, a particular variable impacted on adoption of ICT tools was ICT usage, followed by education level, and ownership of ICTs tools. If collinearity is found in multiple linear regression model, the impact on dependent variables of independent variables can't be explained appropriately. Therefore, when a multiple linear regression analysis is conducted, collinearity should be checked, and to detect collinearity, the variance inflation factor (VIF) is identified. If the VIF is 10 or higher, it means higher the rate of collinearity, and vice versa (collinearity is lower towards 1). The variables as shown in below table 5.10 proves that the lower bond and hence there is no collinearity found between independent variables.

Table 5.10: Summary of multiple linear regression

\begin{tabular}{|l|c|c|c|c|c|c|}
\hline \multirow{2}{*}{ Variables } & \multicolumn{2}{|c|}{$\begin{array}{c}\text { Unstandardized } \\
\text { Coefficients }\end{array}$} & $\begin{array}{c}\text { Standardized } \\
\text { Coefficients }\end{array}$ & t & Sig. & $\begin{array}{c}\text { Collinearity } \\
\text { Statistics }\end{array}$ \\
\cline { 2 - 6 } & \multicolumn{2}{|c|}{ B } & $\begin{array}{c}\text { Standard } \\
\text { Error }\end{array}$ & Beta & & VIF \\
\cline { 1 - 6 } (Constant) & -.391 & .115 & & -3.388 & .001 & \\
\hline ICT usage & .220 & .060 & .403 & 3.681 & .000 & 3.155 \\
\hline Ownership_ICT & .265 & .078 & .279 & 3.403 & .001 & 1.770 \\
\hline Education level & .106 & .041 & .233 & 2.555 & .012 & 2.189 \\
\hline
\end{tabular}

Of the variables, the p-values of ICT usage, Ownership of ICT and Education level were below the significance level of 0.05 which was statistically important. 
Using the unstandardized coefficient in table 5.10, the linear regression model was drawn as shown in equation (3).

Adoption of ICT tools $(\mathrm{Y})=-0.391+0.220 \mathrm{X}_{1}+0.265 \mathrm{X}_{2}+0.106 \mathrm{X}_{3}$

(equation 3)

$\mathrm{X}_{1}=\mathrm{ICT}$ usage, $\mathrm{X}_{2}=$ Ownership of ICTs, and $\mathrm{X}_{3}=$ Education level

To conduct ICT adoption Impact analysis of utilization of ICT tools on adoption of ICT tools, multiple linear regression model was used, and the model is drawn in equation (3). Of the independent variable ICT usage, ownership of ICT, and educational level, where all considered independent variables were determined to have statistical impact on Level of adoption $(\mathrm{P}<0.05)$. These three factors had positive impact on adoption of ICT tools among farmers. In particular it was found that better usage of ICT tools and ownership of ICT tools as compared to education level had higher the impact on adoption of ICT tools. The standardized coefficient of ICT usage, Ownership of ICTs, and Education level was $0.403,0.279$ and 0.233 respectively as shown in table 10 each of which is impact on adoption of ICT tools. ICT usage, Ownership of ICT and Education level presented in the model above explained about the 63.5 per cent of the variance.

Thus, based on the above analysis, it would be more effective to increase the level of adoption of ICTs tools among farmer by focusing over education, and ownership of particular ICT tools.

In table 5.11, it is included a value for Pearson's r, a Sig. (2-tailed) value and a number (N) value. Furthermore, in the below table 5.11, the variable names are in two rows. In this example, see the variable name 'Adoption of ICT tools' in the first row and the variable name 'ICT usage' in the second row, and also see two variable names in two columns which are ownership of ICT and education level, these boxes all contain numbers that represent variable crossings. The Pearson correlation is a measure of the strength of the linear relationship between two variables. Pearson's $\mathrm{r}$ can range from -1 to 1 , where $\mathrm{r}$ of -1 indicates there is perfect negative linear relationship between variables, $\mathrm{r}$ of 0 indicates there is no linear relationship between variables, and $r$ of 1 indicates there is perfect positive linear relationship between variables. 
Table 5.11: Pearson's r Correlations box

\begin{tabular}{|c|c|c|c|c|c|}
\hline & & $\begin{array}{l}\text { Adoption } \\
\text { ICTs tools }\end{array}$ & $\begin{array}{c}\text { ICT } \\
\text { usage }\end{array}$ & $\begin{array}{c}\text { Ownership } \\
\text { ICT }\end{array}$ & $\begin{array}{c}\text { education } \\
\text { level }\end{array}$ \\
\hline \multirow{3}{*}{$\begin{array}{l}\text { Adoption ICTs } \\
\text { tools }\end{array}$} & $\begin{array}{l}\text { Pearson } \\
\text { Correlation }\end{array}$ & 1 & $.757^{* *}$ & $.640^{* *}$ & $.645^{* *}$ \\
\hline & Sig. (2-tailed) & & .000 & .000 & .000 \\
\hline & $\mathrm{N}$ & 100 & 100 & 100 & 100 \\
\hline \multirow{3}{*}{ ICT usage } & $\begin{array}{l}\text { Pearson } \\
\text { Correlation } \\
\end{array}$ & $.757^{* *}$ & 1 & $.653^{* *}$ & $.733^{* *}$ \\
\hline & Sig. (2-tailed) & .000 & & .000 & .000 \\
\hline & $\mathrm{N}$ & 100 & 100 & 100 & 100 \\
\hline \multirow{3}{*}{ Ownership ICT } & $\begin{array}{l}\text { Pearson } \\
\text { Correlation } \\
\end{array}$ & $.640^{* *}$ & $.653^{* *}$ & 1 & $.417^{* *}$ \\
\hline & Sig. (2-tailed) & .000 & .000 & & .000 \\
\hline & $\mathrm{N}$ & 100 & 100 & 100 & 100 \\
\hline \multirow{3}{*}{ Education level } & $\begin{array}{l}\text { Pearson } \\
\text { Correlation }\end{array}$ & $.645^{* *}$ & $.733^{* *}$ & $.417^{* *}$ & 1 \\
\hline & Sig. (2-tailed) & .000 & .000 & .000 & \\
\hline & $\mathrm{N}$ & 100 & 100 & 100 & 100 \\
\hline
\end{tabular}

** Correlation is significant at the 0.01 level (2-tailed).

Overall, there was a strong relationship, and statistically positive correlation between both variables Adoption of ICT tools and ICT usage $(r=0.757, \mathrm{P}=0.000)$, and the relationship was linear, as well as the correlation was adequately represented the strength of relationship between these two variables. as well as in the next correlation box, there was also found positive correlation between the variables that's are Adoption of ICT tools and ownership of ICTs tools ( $\mathrm{r}$ 
$=0.640, \mathrm{P}=0.000)$, and in addition, in last correlation box, there was relationship and statistically positive correlation between both variables Adoption of ICT tools and education level $(r=0.645, P=0.000)$, however, as more small land holdings banana farmers from selected area would be educated, or move towards technical education, the chances would increase automatically, similarly we found the moderate positive correlation between two variables education level and ownership of ICTs tools $(r=0.417, \mathrm{P}=0.000)$. So it indicated that as education level would increase, number of the ownership of ICT tools would increase at high level.

\subsubsection{Conclusions about ICT adoption in Small Holders Banana Farmers and Traders}

This study revealed some of the numerous benefits and challenges associated with the use of ICTs initiative in smallholder farmers and traders. The development of ICTs has facilitated the dissemination of knowledge and information and it has revolutionized the use of technology for smallholder banana farmers in production, and traders for increasing their trading business and has made provision of market information to maximize the returns to banana crops. However, there are challenges in making ICT initiatives available to a large number of the small land holding banana farmers from the remote area who are full time associated with banana farming. Thus, there is a necessity of an integrated approach that would help to solve the problems faced by farmers in using ICT applications, such as acceptability, accessibility, simplicity, timely \& useful information related to banana farming and trading sector in their respective locations.

The study also revealed that the most significant influencing factors that constrained farmer, namely poor access of internet in field area, lack of electricity, and there is no guidelines from agriculture officers. Beside this, language is found to be the most significant factor which has created barrier for both farmers and traders group, and prevented the adoption of the new technology. Similarly, this clearly indicates that there are less chances for accepting the food traceability in this sector even though such technology is available in the market. As expected, both variables ICT usages, ownership of ICTs and education have shown more linear relationship with adoption of ICTs tools among smallholder farmers in Jalgaon district, India. 
PhD Thesis

Keshav Prakash Dandage

Experimental Works and Studies

66 I P a g e 


\subsection{Food traceability through web and smart phone for farmer's agriculture products in India: cloud services and web API's}

\subsubsection{Introduction}

In the previous section (section 5.1) we have mapped the journey of small holder farmers and their struggle to get their right to dignified living against the market and government schemes as well as examined factors which affected or influenced the ICT tools adoption among small holder banana farmers in Jalgaon district, India. During the field survey it was found that significant number of rural farmers had no knowledge about ICT usage in farming sector to increase their production and market. In most of the survey area the ICTs enabled services are unusable due to poor construction of Infrastructure and poor economic condition of rural farmers in Jalgaon district, India. It was possible to establish a link between this section and the argument made in this thesis that the adoption of ICT and traceability system in India face numerous challenges amongst which illiteracy and lack of infrastructure was the major hindrances.

Apart from this, the rising cost of raw materials and other production inputs has slowed down the farming business and farm production in India thereby making the lives of farmers even more miserable. In addition, long queue of brokers or middle men who are involved in selling product as noticed in the survey area further reduces the farmer's profit. It was also observed during the field survey study that farmers need a strong support to protect their land and provide them constant rights to supply farm produces in market at affordable rates without any brokers and with help of government regulated body and agriculture officers. Hence effective value chain management with the help of technology is the only gateway to minimize the risk faced by the farmers and regulate the markets. The contention of this thesis that technology has the potential to transform societies by bringing changes in the way people perform their daily activities, particularly its role in bringing significant changes in the life of rural poor is further advanced in this section. 
This section focuses on analyzing the impact of food traceability technology in improving lives of rural population. Food traceability technology involves tracing the origin of the food and its destination, from where it will be distributed to different end users. This would provide complete visibility of farmers from field to market and track the source of value chain even in the remote area of the country. It would facilitate the direct selling of farm produce providing farmers more access to market as compared to stepwise process. With this as an outline, we have designed a simple web-based traceability portal using cloud infrastructure coupled with API connectivity, which would be useful for farmers and other trading actors to increase their production, supply network and annual income.

Food traceability is the key element in today's food market. Product tracing has become mainstream and has the ability to trace potentially contaminated product, the consumption of which may cause an adverse health impact, through the supply chain(Aung \& Chang, 2014; McEntire et al., 2010). In addition to this the Traceability at any stage in the food chain has become necessary to ensure food product quality and safety to prevent from unintentional act with unintentional harm (Spink \& Moyer, 2011). The recent article, "Assessing the Value and Role of Seafood Traceability from an Entire Value-Chain Perspective" introduces the seven comprehensive, sustained, and intensive benefits of traceability systems which construct and develop an hidden driving force behind every successful business which are as follows: Improve quality, Improve product recalls, Improve inventory tracking, Improve food safety, Improve customer service, Respond to consumer demand, and Verify harvest date and location (Sterling et al., 2015). Further, controlling is the major monitoring part of every system, though it has been framed strongly, as well as more action is required to bring improvements in the current traceability system (Sterling et al., 2015; Thakur \& Hurburgh, 2009).

The fifth-generation technology has completely changed the way of doing farming, increased the crop yield, and has brought super innovative technology in food business. In the present time, technology has entered almost every field from science to fiction. There is a shift from the old technology which is lagging behind in today's globalized world, to the upgraded technology which is increasing the feasibility and efficiency of doing business. Even though, it is unrealistic 
to think that technology alone would bring solution to all the problems related to production and development of the country, still all the recent experiences shows the positive correlation between the technological development and productivity of food supply chains (Organisation Economic Cooperation Development (OECD), 2014). However, before adoption and implementation of these technologies, especially in developing countries like India, the farmers need to be provided with some short training or technical education. It has been found that farmers from developing countries are less interested in using new smart technology though it is available in their territory, because technology requires specific parameters like internet access with ultra-bandwidth and electric power, and if farmer fails to meet these basic criteria, he would not get benefit from technology; additionally lack of knowledge and low rate of literacy amongst Indian farmer community is yet another factor responsible for slow paced in technology (Mahendra Dev, 2012a).

In India, farmers are still using traditional way of farming, from cultivation to harvesting, and from market to consumer. An unpredictable weather conditions, loss of agriculture land due to soil erosion, and bad impact of pests and diseases on crop eliminate the profit and productivity of smallholder farmers. In this scenario only the latest information and giant source of knowledge would bring the transformation with support of smart technology which is available in smartphones (mobile Phone) such as sensors, GPS and GIS, which supplies unlimited services to farmers. In recent years, role of ICTs and IoTs have increased significantly and solved many challenging issues related to agriculture field across India. Cloud computing in agriculture provide an open platform for innovation and information services. The appropriate use of this technology would help farmers in terms of accessibility and affordability.

\section{Competitive Advantage of Food Traceability to Value Chain Management in India}

In today's world Agro-food sector is facing more competition at all level of development in international market and self-contained (regional) country market ((FAO, 2011; Organisation Economic Cooperation Development (OECD), 2014). Customers and food businesses both are desiring best and quality products. Large agriculture producers and agriculture business sectors 
are trying to ensure more sustainable, safe, innovative and competitive food supply. On the other hand, demand of agriculture food product has highly increased with growing population resulting into reduction of current and future supply of production of food which has effected equilibrium, quantity and prices in market.

The concept of food traceability has been extensively researched and several researchers have expressed their views on the parameters that business firm need to take into consideration for developing food traceability system at various levels which includes production, processing, and distribution as well as in retail and foodservice(Sterling et al., 2015). The new ICTs and IoTs based technologies including electronic barcode, RFID, Infrared, GPS, and Biometric Sensors etc. would play a vital role in monitoring the problems faced by farmers and other actors involved in supply chain and enhance the efficacy of traceability systems for future. An identified definition of traceability which is useful for many research area, defines traceability as, "the ability to access any or all information relating to that which is under consideration, throughout its entire life cycle, by means of recorded identifications" (Olsen \& Borit, 2013).

In India, many traditional food businesses have entered the modern food industry to take advantage of upgraded technology for value addition and quality production (IBEF, 2014; India Brand Equity Foundation, 2017). In India, the largest portion of household income or revenue is spent on food and groceries. The food supply chain is very complex system in India, where all categories of actors are involved in this race, from hawker, street seller to retail shops and food companies. An effective supply value chain management process would certainly add values to traceability system by minimizing potential risk and maximizing likelihood for system to remain fair and open, and build up greater transparency in retail and food services.

\section{Farmer Profitability: Managing Risk in Agriculture Supply Chain in India}

Currently, India's large group of smallholder farmers are engaged in producing the food for giant population around 1,200 million, while owning less than 2.00 hectares of farmland (R. B. Singh et al., 2002). An increased cost of raw materials and other production inputs has rendered 
farming business less competitive in the country and has put an enormous strain on profits of manufactures which poses a great risk to the supply chain. If this crisis continues, farmer's downfall would find more ground to grow and unthinkable situation might occur in coming years, most likely as a direct result of economic downturn and recession. But if the younger generation equipped with the latest technology decide to enter the farming field then this scenario might change. With the support of young educated farmers and right directional education, farming production and farming related business would become more profitable in less than a decade. In addition, this might help the food production in India to flourish and reach great height.

Thus, the current scenario in India is profitable for Indian agricultural industry, local fruit and vegetables growers due to dissemination of information and increased involvement of young and educated people in smart farming program and this gives clear indication of the start of a new trend of running an agricultural business in the 21 st century (Pen, 2010). The most successful and influential companies in India, including Reliance and Tata, have already initiated 'start up business plan' for local grower to find new value-added products and niche markets through their websites and social media which provides technically sophisticated business savvy with an entrepreneurial approach, including use of wide varieties of technology and information tools from newspapers, radio and television, to the Internet, mobile technologies and social media. For illustration let us of take the farming profitability in India, in current year 2016-17. The State-level BT (Bacillus Thuringiensis) Cotton Crop farming expenditure data estimate suggests that farmer has spent near about 60 per cent expenditures on fertilizers, pesticides and labor activity, and their total amount of net income earned is between 30 to 60 percent during monsoon cropping season (Kharif season from July to October) (see below Table 5.12).

The below table shows the remarkable expenditures which eliminated the profit of farmers where the cutting cost of labor and fertilizers only work out to make a profit. Only increasing productivity and reducing the cost of production would be beneficial for making profits and sustaining farm enterprises. Whereas in the present time the new initiatives have changed the face of agriculture, and "coordinating entrepreneur" has gained more popularity among farmers 
group in India. The interfering role of intermediaries are eliminated and they are directly working with farmers to find out better market and promote their products.

Table 5.12: Farmer's expenditure

\begin{tabular}{|l|l|}
\hline Particulars & Expenditure Cost (year 2016) \\
\hline Ploughing & $\$ 10.51-15.02$ \\
\hline Seeds & $\$ 30.05-36.06$ \\
\hline $\begin{array}{l}\text { Labour- Sowing } \\
\text { Spraying }\end{array}$ & $\begin{array}{l}\$ 7.51-10.51 \\
\$ 45.08-60.11\end{array}$ \\
\hline Chemical Fertilizer & $\$ 90.11-97.68$ \\
\hline Chemical Pesticides & $\$ 75.14-105.19$ \\
\hline Weeding & $\$ 75.14-90.17$ \\
\hline Irrigation / drip & $\$ 30.05-37.57$ \\
\hline Fuel and Electricity Costs & $\$ 30.05-37.57$ \\
\hline Market Charges (per Quintal) & $\$ 30.05-37.57$ \\
\hline Administrative and field cost (per Farmer) & $\$ 30.05-37.57$ \\
\hline Total & $\$ 7.51$ \\
\hline Average Yield & $\mathbf{\$ 4 6 1 . 3 1 - 5 7 2 . 5 3}$ \\
\hline Gross Income ( Rate: \$65.04 per Quintal ) & $\mathbf{\$ 7 8 0 . 4 8 - \mathbf { 8 4 5 . 5 2 }}$ \\
\hline Net Income & $\mathbf{\$ 2 0 7 . 9 5}$ to 384.21 Profit \\
\hline
\end{tabular}

US Dollar Exchange rates against INR for October 2016, 1 US Dollar = 66.5409 INR (Rupees); Figures Per hectare.

Source: Hindustan Times and Estimates Provided by Farmers of Maharashtra, calculation done by authors

Beside this, it gives a new identity to high-quality food product through their responsible supply chain management system. Supply chain enables to control the flow of products and information if openly shared with a variety of parties including suppliers of raw materials, manufacturers, retailers and consumers. According to Global Food Traceability Centre (GFTC), supply chain is 
the system of organizations, people, activities, information and resources involved in producing and/or moving a food product to the consumer. Many leading Indian companies like TCS, ITC, Reliance and Tech Mahindra are actively involved in preparing the latest tools and technology related to supply chain management software to secure supply chain tracking and traceability for food security.

\section{Farmer Trading gateway through Direct and Stepwise process in India}

Farmer is the main driving force for both market and farm produce as shown in the figure below since they make their earning by selling out their farm production that majorly comes from farm field, greenhouse or new designed polyhouse. In India, most of the farm and greenhouse or polyhouse are run by farming community. As Input (Farm Production), the farmer purchases the materials like seed, fertilizer, pesticides from the government recommended or private supplier. As Output (Trading Gateway) farmer sells them out which helps to generate the cash flow for farmer who in turn spends this cash flow on seedling, fertilizers, and pesticides during farm production. At the end, an earned farm produce becomes cash generating commodities when it enters into market through complex process gateway basically which is stepwise and direct process.

Stepwise Process: In this process, the farmer has to contact a particular authority either government or private firm for selling out earned farm produce. In this case farmer has inverse relationship with trading actors like Manufacturer, exporter, distributor, retailer, and consumer / end user. It means trading actors and consumer are completely unaware about the source and farmer, as well as intermediaries and broker are the main dealer who mostly deal with farmer or grower.

Direct Process: In this process, the farmer has to contact the various trading actors and are selfresponsible to find out the right market for their produce. In this case, farmer develops the direct relationship with the trading actors like manufacturer, exporter, distributor, retailer, and consumer/end user on base of behavior and quality products. It means direct to consumer market, 
and farmer can directly get connected with trading actors and consumers without intermediaries and broker.

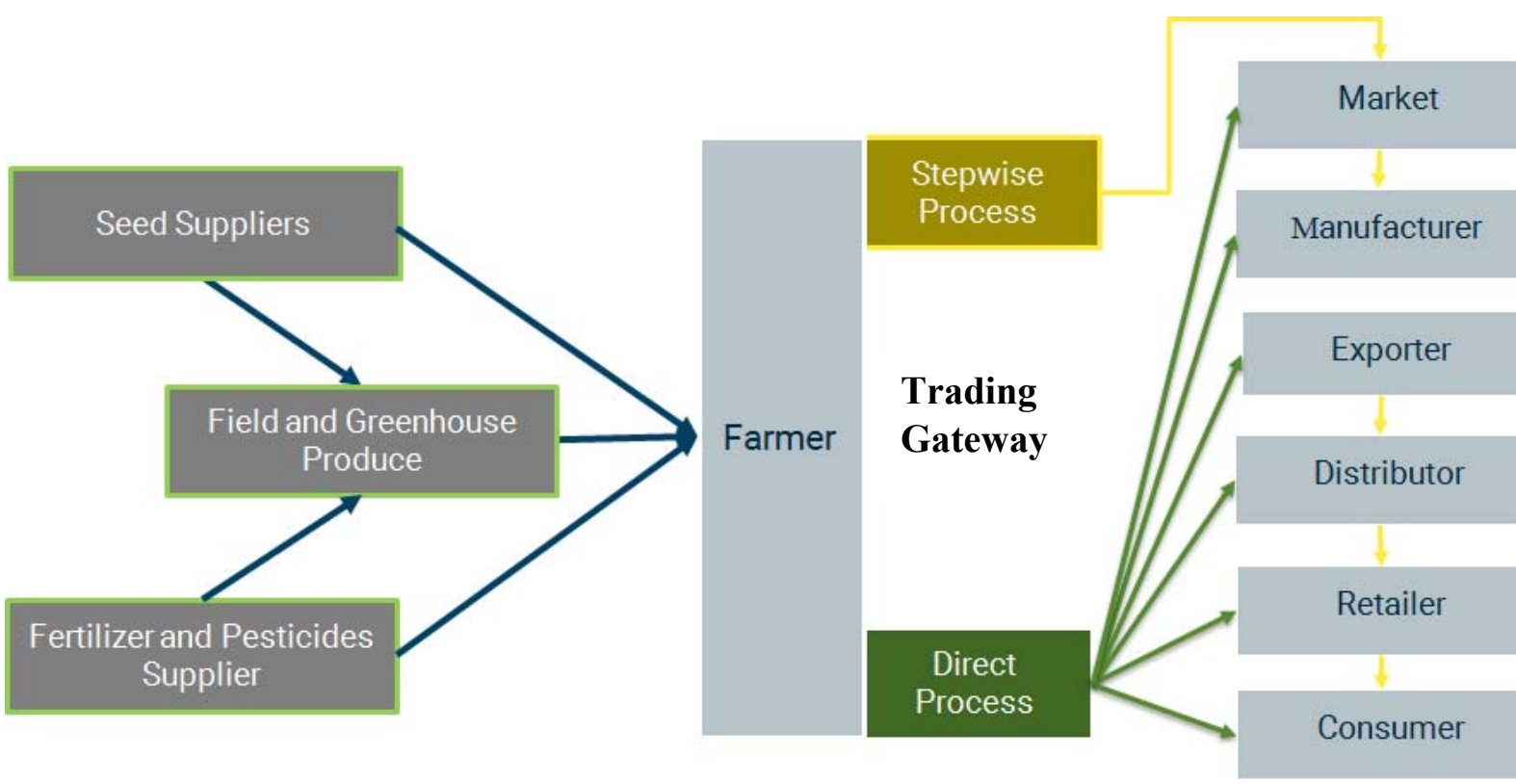

INPUT- Farm Production

OUTPUT- Trading Gateway

\section{Cash Flow}

Figure 5.5: Farmer trading gateway through direct and stepwise process in India 


\section{Go connected with technology in Indian agro food sector: Certification, Product ID, packaging and Labelling}

A long time ago, food was produced traditionally and consumed locally in own territory, and generally most of the consumers were preferred to buy sustainably-grown food products from local farmers (Painter, 2007). There was no need for packaging, and hence quality of food and risk associated with regional foods always remain entangled (AZEVEDO, 2015). With the rise and success of barcode, the face of doing businesses of new generation has changed and it has led to reformation in information sector, and unveiled many ways for retailers by providing them mobile and ubiquitous business (Milne, 2013). The understanding of modern technologies such as the ICTs, IoTs, mobile computing, customer relationship management (CRM) software, Barcode, Biometric, RFID, and infrared techniques has helped to develop smart product packaging digitally and become global(Dandage et al., 2017).

According to Yadav et al. (2015), in India contemporary food issues have increased from biological and chemical contamination to the use of technologies applied to modern agro-food systems for processing and manufacturing. This has resulted into food shortage and food safety issues, as well as affects individual and society. These affected and industrialized foods are checked and controlled by regulatory body like FSSAI and BIS where interaction of standardized rules and procedures tightly develop the security and help to produce more safety food for the consumer and business. At the same time, it gives a systematic approach to perform advance product road-mapping and support to solve the unpredictable activities in India (Yadav et al., 2015).

\section{Product ID, Packaging and Labelling for Indian food products}

According to Mintel Purchase Intelligence, smart packaging gives vital or central importance to brand to gain an easy entry into market, retail, or wholesale selling, that ultimately facilitate trust in brand, and acceptance in new categories (Mintel, 2017). 
In terms of food, in India, many leading non-alcoholic beverage industries like Dabur India, Red Bull, Tetra Pak, Pearl Drinks Ltd, Bengal Beverages, Jain Irrigation Systems, Coca-Cola India and PepsiCo India are using the high tech aseptic Packaging from Tetra Pak India, and readable Labelling along with electronic barcode from GS1 India to enlarge their presence, visibility and interaction with consumers(TNN, 2017).

In India, compliance with FSSAI regulations is the only way to sort out problems (food-related public health risks) before they turn into serious outbreak in terms of food safety, quality, packaging and labelling. According to the GS1 India, an electronic barcode is the perfect gateway to identify the product by using tracing and tracking process and it has worked well for point-of-sale systems. Today's handy mobile smart technology is able to access readily, and create more awareness along with transparency in consumer, and supply chain sector. In the recent times, Hologram, alphanumeric code, and GI (Geographical Indication) tag are being used as product identification (ID) and labelling that is printed on packaged food stuff in Indian market as well as international market.

The labelling of Food products also plays a pivotal role for preventing illness caused by spoiling food. There have been some new initiatives in this area in the recent times that has changed the way of doing business. A graduate student of Brunel university, United Kingdom, Solveiga Pakstaite, created a bio reactive expiry label (gelatin based sticker) which is a one-touch system that alerts when food decays, as a result label turns from smooth (fresh) to bumpy (expired) unlike "Sell-By, Best-Before" and "Use-By" dating systems (Pakstaite, 2015). Similarly, researchers at the University of Alberta are creating smart labels for food packages that can detect harmful microbes like E. Coli and salmonella that causes food borne illness. It would be helpful for consumers and food suppliers, as a result the label would change its color when food comes in contact with bacteria (Pratt, 2015). 
PhD Thesis

Keshav Prakash Dandage

Experimental Works and Studies

\section{Food Safety system and quality certification for Indian food products and food business}

As the food world rapidly expanding, there is an urgent need to innovate and change the outdated methods by applying food safety management plan. Food business needs to set up the right protocols to meet all the requirements as per FSS Act, 2006. This would help business run on the right track and there are more chances for it to flourish rapidly. In addition, the food safety management and quality control system help to impose the strong preventive measures against food frauds, brand damage, monetary losses, and public health risk. The preventive controls include food safety agencies, anti-fraud regulations, and law enforcement agencies, which works under FSSAI and BIS India. Both have ongoing effort to secure the food supply chain, and managing food safety risk.

In India, Specific controls and Management System Standards in Food Safety involves Indian standards/ International Organization for Standardization) IS/ISO 22000 : 2005 for Food Safety Management Systems - Requirements for any organization in the food chain, IS 15000: 2013 for HACCP - Requirement for any Organization in the Food Chain, IS/ISO 22005 : 2007/ISO 22005: 2007 for Traceability in the Feed and Food Chain - General Principles and Basic Requirements for Systems Design and Implementation, and IS/ISO 22006 : 2009/ISO 22006 : 2009 for Quality Management Systems Guidelines for the Application of ISO 9001 : 2008 to Crop Production (BIS, 2015). It regulates manufacture, storage, distribution, sale, and import of food to promote health and safety of consumers. FSSAI authorities have recently announced that e-tailers (local and wholesale shops, e-commerce companies) also require to obtain license/registrations under FSSAI and comply with other relevant regulations (Ministry of Health and Family Welfare \& Food Safety and Standards Authority of India, 2016).

\section{Cloud service and web API's Maximizes Usefulness of Food Safety System Data in India}

In present days, the adoption of cloud computing is more beneficial for the enterprises that results in better interaction with customers, scalability, immediacy, cost containment, efficiency, and accessibility for the instance and emerging market of business. According to Gartner 
research report, the cloud based CRM market expected to grow at higher CAGR (compound annual growth rate) during forecast period (between 2018 to 2020) in India. These growing services would be helpful for small and medium size enterprises (SMEs) and government agencies where Infrastructure as a Service (Iaas) is set at the top which captures nearly half of the total cloud based market which is estimated to reach USD 2.03 billion by 2020 as compared to other services like Software as a Service (Saas) which is around USD 1 Billion, and Platform as a Service (Paas) would reach about USD 0.29 billion (Gartner, 2016). Amazon web services (AWS) gives the precise definition of cloud computing, it is the on-demand delivery of compute power, database storage, applications, and other IT resources through a cloud services platform via the internet (Amazon, 2006). It is more beneficial for the supply chain industry where product can be tracked easily without worrying about loss of product during transport, as well as it can get more real-time accuracy and traceability across the entire supply chain, and cut down transactional cost.

In India, the world famous Indian IT companies such as TCS, Infosys, Wipro, Tech Mahindra, Oracle financial services, Mindtree, Mphasis, Rolta, and Cyient etc., are playing a major role for developing the supply chain of the country more efficiently and effectively. Nevertheless, cloud computing is still in its early stage, and faces more challenges related to data security, and lack of quality infrastructure across the country (S. Ray \& Lakshmana, 2017; TechSci Research, 2015). Many new emerged cloud based CRM services provider companies like Tally Solutions, Protostar, WorkXmate, Busy Infotech, Karyins india, Intuit Technologies, Foradian, SAP India, Marg Compusoft, and Ramco System are playing the lead role in operating CRM market in India and are working in close collaboration with small scale business at affordable rate. According to Gartner report, most of the manufactures and producers have adopted this advanced technology to scale up small business, with integrating food safety management solution like cloud based ERP (Enterprise resource Planning) system that facilitates real-time control, electronic document control, quality, and traceability, as well as increase effectiveness with more customer retention (Gartner, 2016; TechSci Research, 2015). 
In today's competitive world and marketplaces, the business enterprises have to go through innovation, upgradation of technology, and adoption of new technology; in order to maximize their production, the firm needs to start using cloud infrastructure coupled with API's ( Application programme Interfaces) connectivity which gives a single unified platform to rapidly expose enterprise data to mobile devices, web apps and connected things in secured control way, and simultaneously contribute to the business growth(IBM, 2016) (IBM, 2016).

As recently suggested by an international analyst firm Gartner that web APIs are fast innovative solutions which have digitally transformed the activities of businesses to respond rapidly and change their needs accordingly (Gartner, 2014). Similarly, Boomi (2015) reported that web APIs deliver the real business value to the enterprise, reduce time-to-market and resolve errors (Boomi, 2015). Companies, employees and customers all together interact with web APIs to provide secure access to real-time data sharing (Mulesoft, 2017). A web API has thus become the digital gateway that connects different category of devices and applications (Mobile devices, cloud computing, Internet of Things, big data and social networks), and helps to connect sensors to internet and with each other. A web API technology, which has made things easy to deploy for enterprises and end users, and hence API needs to be tracked and managed (Gartner, 2014; Mulesoft, 2017). 


\subsubsection{Material and Methods}

The web application generated to support the traceability system has been developed following methodological procedures

\section{The View of the Architecture}

The web API facilitates seamless connectivity and helps to deliver data by simply running back and forth between applications, cloud servers, databases, and devices which allows computer to operate them.

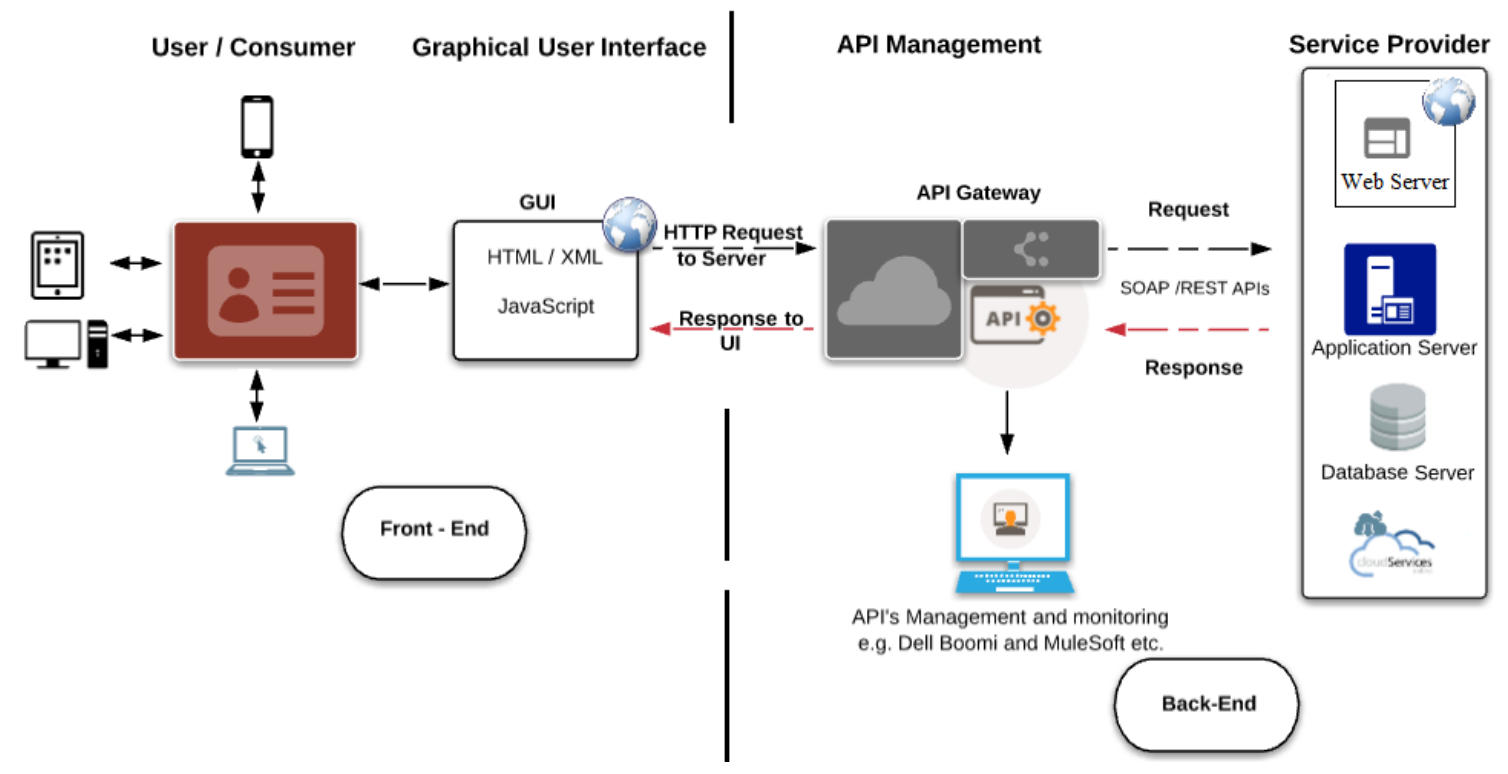

Figure 5.6: Sequence Architecture of an entire Application

Source: Dell Boomi; 2015, IBM, 2016; and MuleSoft, 2017.

The above figure shows the entire application process is divided into two parts which are BackEnd and Front-End process. In Back-End process application data is extracted and processed through API like simple object access protocol (SOAP) or representational state transfer (REST) calls, whichever is preferred by users, and delivers to graphical user interface (Front-End) which 
allows users to interact with web application or software. This API gateway is managed and monitored by API management service Platform like IBM, MuleSoft and Dell Boomi. API gateway receives request from Uniform Resource Locator (URL) which uses the hypertext transfer protocol (HTTP) or hypertext transfer protocol secure (HTTPS) as server for the Frontend application. As the server connection is established from the Front-End program the API result is displayed on web page (Graphical user interface) whenever user makes a certain request thorough web browser to web server application.

\section{Methodological Approach for the generation of web-based traceability portal:}

Today most of the users are familiar with the process of searching on web browser. On this baseline, the web-based traceability portal would respond properly, the user requested information is obtained through the creation of collaborative environments for data processing, archiving, and transmission, and creates front end displayed is created in a web browser which enables the retrieval of information using the web.

As shown in figure below, User Devices, Graphical User Interface using Dreamweaver software, API-single unified platform helps to monitor and control to all web APIs, and the data service providers (Web Servers) all are the main actors which combinable creates the online web-based traceability portal. 


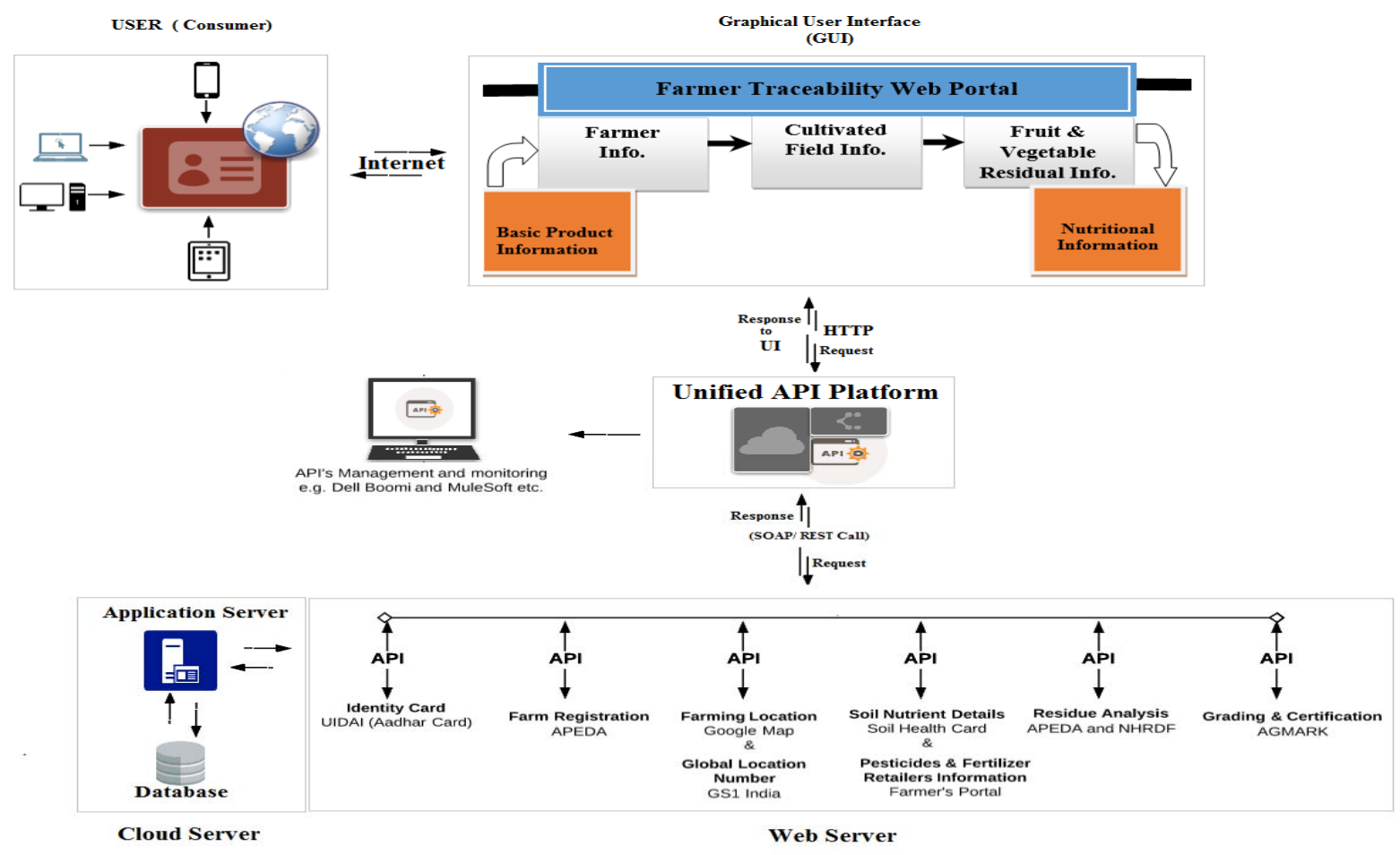

Service Provider

Figure 5.7: Architecture of an entire Application of farmer production traceability system

Source: Dell Boomi; 2015, IBM, 2016; and MuleSoft, 2017

The web-based Traceability portal is simply website, where hypertext markup language (HTML) or Extensible markup language (XML) and JavaScript are used to write web pages using software tools like Dreamweaver by Adobe. Users would access this website with the help of available devices like mobile, tablet, laptop, and personal computer etc. through the web browser (like Google Chrome, Fire fox, Internet Explorer). Further, as can be seen in the figure, web browser connects to web server through API (single unified platform) and sends HTTP request for the desired web pages, then web server receives request and checks availability for the desired web page, web browser again receives the page back and the connection is closed. 
With the help of sign-up form, the user like consumer, retailer, manufacturer, exporter, food business entrepreneurs and other actors would get registered to access the farmer's data. In user profile page, user would be able to search local farmers using the drop-down menu and quick filtering checkbox, for example, in this case user selects a particular information like soil health card holder (about soil nutrients) in Jalgaon District. Then user directly interacts with Soil health website to access the soil nutrient database to find out if any farmer from Jalgaon district is a soil health card holder. If the page exists, the web server sends it back and would display the list of all farmers from Jalgaon district who are soil health card holders on webpage of online webbased traceability portal, and the same applies to all websites. If the server cannot find the requested page, it would send an HTTP 404 error message. (404 means 'Page Not Found').

Besides this, if the user needs an information with respect to other variables like the proof of national identification card from UIDAI (Unique Identification Authority of India), registered farm information from APEDA, GLN from GS1 India, Residual analysis, it is a testing of produce from NHRDF (National Horticulture Research and Development Foundation), or InfoLNet (Indian food laboratory network) and final grading and quality certification from AGMARK, then in such case online web based traceability portal interacts with web APIs that aggregates information from all concerned websites (like UIDAI, APEDA, GS1 India, Soil Health, NHRDF or InfoLNet, and AGMARK as per user's request. Whereas through the web API interfaces, online traceability portal gets information from the server database of websites over the internet to find soil health card, GLN of field, farm registration information and other variables, and the concerned API then connects to particular server database of websites. Then web server gives response through API like SOAP or REST calls to user request and delivers the requested information right back to the online web based traceability portal which is then displayed to the user. 


\subsubsection{Results from Graphical User Interface (Front-end) Program:}

This below figure 5.8 represents the home page of the application (web-based traceability portal) where user get registered with help of "Join Free" registration form and access the entire registry of farmers through this home page.

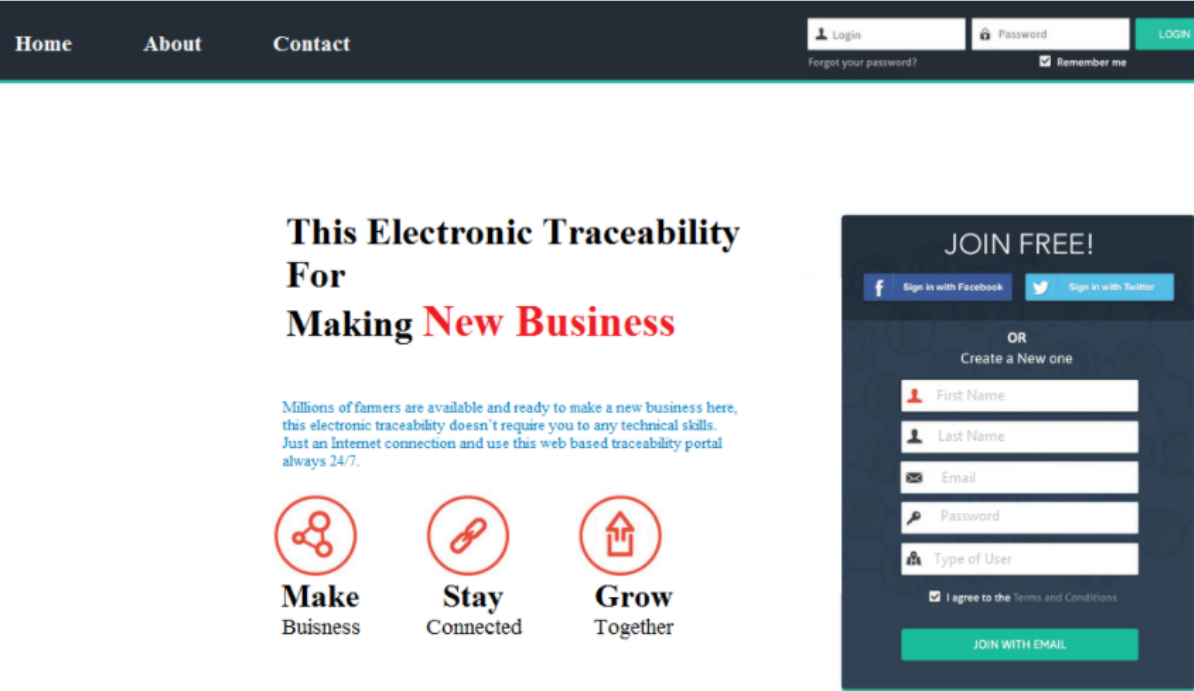

Figure 5.8: Home Page of the application 
PhD Thesis

Keshav Prakash Dandage

Experimental Works and Studies

In this below figure 5.9 Indoor Facilities has presented for the registered user where user can select the farmers from their neighborhood area by clicking on particular area, easily find out the information of the produces according to their location.

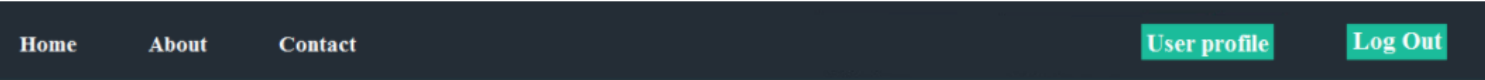

Search Local Farmers

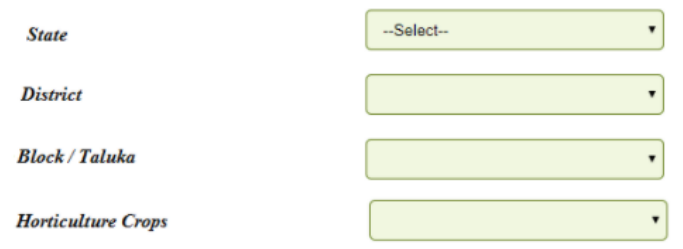

Filter the database by

$\checkmark$ Id $\square$ Farm Registration $\square$ GLN $\square$ Soll Health Card

Certificate of Analysis Grading and Quality Certificate (AGMARK)

Search

Noout pages Pinacy Terms Help

Figure 5.9: Indoor Facilities presented after registering by User 
PhD Thesis

Keshav Prakash Dandage

Experimental Works and Studies

In this below figure 5.10, user would select the particular choice of produces from their nearby location using drop down menu and filtering the database using check box options
Home

Filter the database by

Figure 5.10: Using drop down menu and filtering the database with Checkbox options 
In this below figure 5.11, user finds the list total requested farmers, and in this farmers list, all farmers are registered along with their identification has been verified using secured Aadhar web API techniques, so all the information will be accessed to user only after completing the authentication process

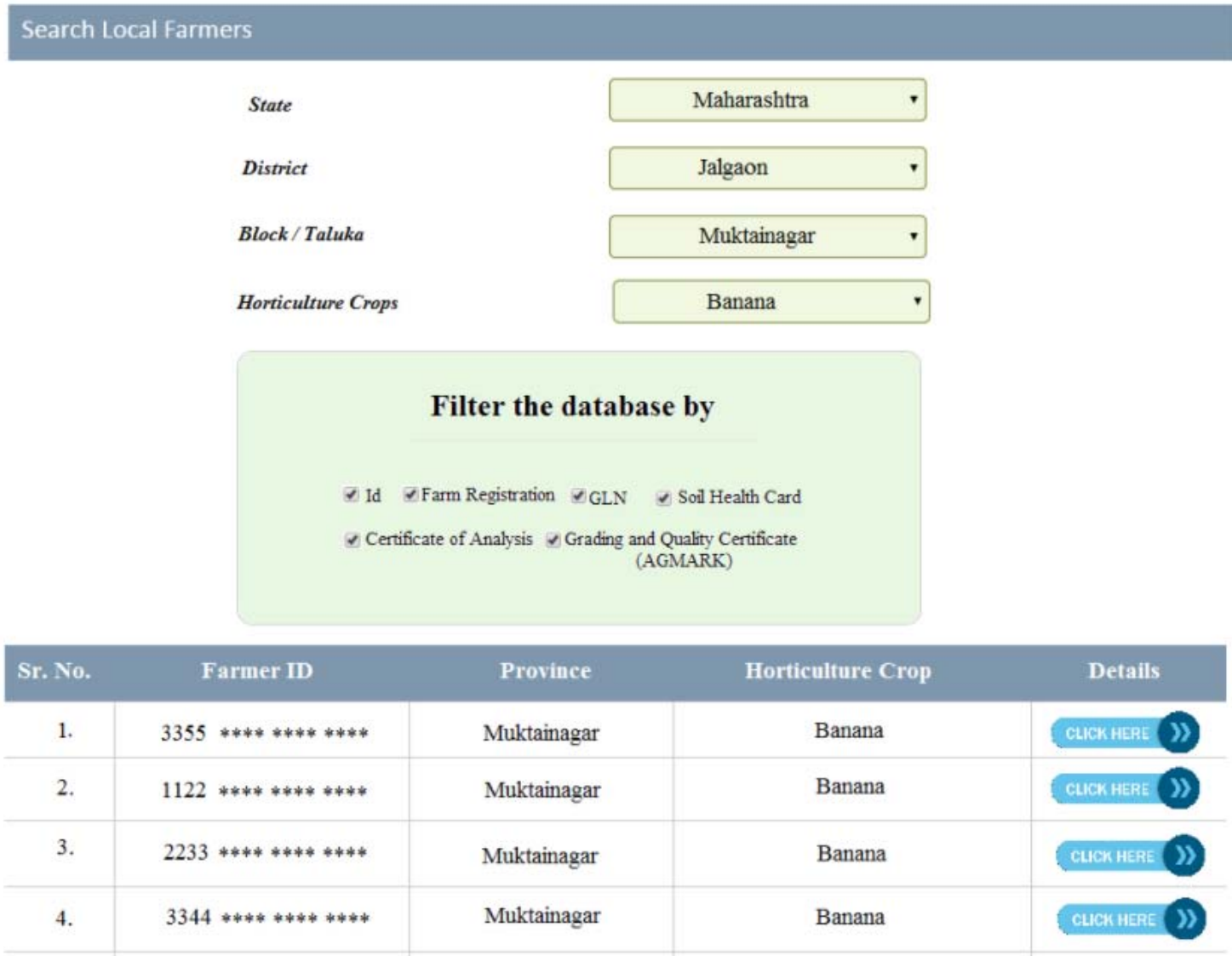

Figure 5.11: List of farmers presented on table with Farmer ID, Province, and Horticulture crop. 
In this below Figure 5.12, all the registered users must have their own mobile number, so user can easily receive one-time password securely on their own devices. The user enters the one-time password which has received on their mobile phone, and then an authentication server validates the logon request. It removes the possibility of a user registering with fake mobile number, this module checks the existence of mobile number and the ability of user to access the mobile number. This is the very important process which has to complete by all the users so by this process there is no fake user will be entertained and cheated to the farmers and neither be taken for granted and disadvantages of farmers confidential registry information.
Home
About

User Authentication Details

Please Enter These Details to Authorize

Please enter these details to authorize access to farmer's database

One Time Password

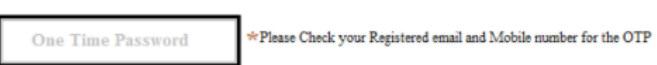

Submit

Figure 5.12: Providing security for farmer's data using One Time Password (Authentication Page) 
Once an authentication is done by user the next page will appear to user which is final result page, which can be seen in below figure 5.12, where user finds farmers registry and know everything about farmers and their produces certification like Soil health card, Geographic location number and residue analysis test certificate.

This result page has divided into three sections including basic information of farmers, traceability information and farm location. With help of these information the user can be easily developed the contact with particular requested farmer by all means like email, mobile number and postal address. All the information like soil nutrients, product laboratory testing report, quality and grading certificates and the farm geographic location number, have been obtained through government web servers using web API technique for the beneficial of farmers and users like consumer, distributor, traders, exporters, and manufacturers.

\section{$\begin{array}{lllll}\text { Home } & \text { About } & \text { Contact } & \text { User profile } & \text { Log Out }\end{array}$}

BASIC INFORMATION OF THE FARMER
\begin{tabular}{|l|c|}
\hline Aadhar Id & 335522114466 \\
\hline Full Name & Keshav Dandage \\
\hline Residential Address & At Post Taluka Muktainagar, District-Jalgaon 425306 \\
\hline Mobile Number & +919876543210 \\
\hline Email Id & xyz@gmail.com \\
\hline
\end{tabular}

\section{TRACEABILITY INFORMATION}

\begin{tabular}{|c|c|}
\hline Aadhar Card (IDAA) & $\nabla$ \\
\hline Farm Registration Number (APEDA) & V \\
\hline Geographic Location Number (GS1 India) & $\nabla$ \\
\hline Soil Health Card (Soil Health) & $\mathbf{V}$ \\
\hline Certificate Of Analysis (NHRDF) & $\nabla$ \\
\hline Certificate of Grading and Quality (AGMARK) & $\nabla$ \\
\hline
\end{tabular}

\section{FARM LOCATION}

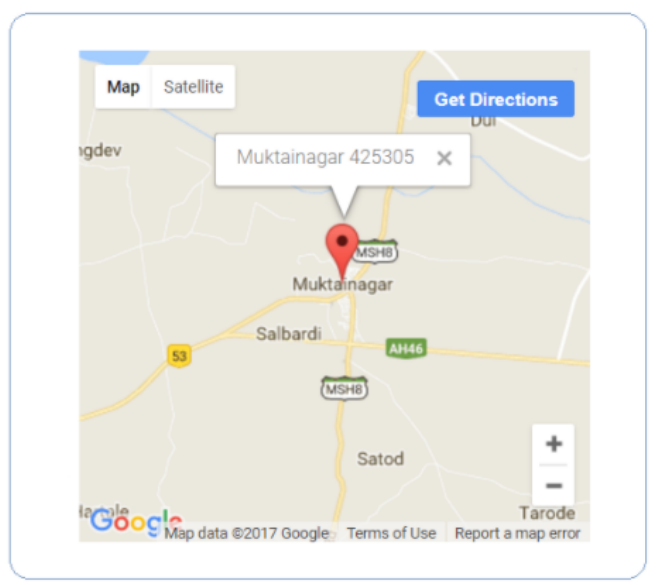

Figure 5.13: Final Result page

89 | P a g e 


\subsubsection{Conclusions about food traceability through web and smart phone}

In today's globalized world food safety has become a major concern and this has increased the importance of traceability, in particular traceability of food products. Technologies which help to develop traceability system, especially in agri-food sector, has started gaining popularity in this changed scenario. Within this context, the present paper tried to analyze the contribution of web services and web API technology for the development of web-based farmer production traceability system (FPTS) for agricultural products in India. This system would enable buyers and sellers to use agro products which have traceability code. Further, Farmer's production traceability system would help companies to improve the food safety management involving self-monitoring, inspection and certification and improve the process of fresh food products supply chain and market penetration.

The government initiatives such as UIDAI, APEDA, NHRDF, Soil Health Card, GS1 India and AGMARK would facilitate the Farmer's products traceability system function efficiently and enable the agro-food business to better manage their risk by allowing them to identify the perishable food products. Thus, the web-based application of Farmer's Traceability System provides a platform to the farmers and Agro-firms, manufactures, distributors and consumers to connect with each other and lead to greater transparency and efficiency. As shown in the figure 3, with the help of easily available devices like smartphone, tablet and laptop the users would be able to easily access the cloud-based web portal which display appropriate information and available certificates regarding farmer's raw material and its quality on the screens, it is easy to read and understand even by those having no knowledge of technology. This is done by means of web APIs which displays the details about the current data which is stored in the government database (Web Server). With the help of farmer's traceability system would thus, help the consumers get the complete history of the purchase farmer product resulting into build up trust between the consumers and the producers. 


\subsubsection{Limitations and Future recommendations}

1. Still the government database is not readily available for public, and it shows many errors and dis matching with other old database

2. Web servers and Web API both modern technological web development application, which are useful and easy to communicate over internet with seamless access, need to be developed by government for their available database

3. Web API is the best way for integration with mobile or other website, where custom web services should be provided by Indian public and private IT service providers to the layman. 
92 P a g e 


\section{Chapter 6}

\section{Discussions}

In this chapter it is presented a discussion of the results with regard to the International state of the art about the development and implementation of food traceability system in India

\subsection{Development of the Food Traceability system in India}

In section 3.2, effective traceability techniques in India introduces the basic food traceability techniques which are currently used in India and studied their operational features and impact on practices. Initiatives of traceability in India with the help of APEDA and GS1 India is described in detail in this section 3.3. These techniques are used for controlled supply chain, good quality of agriculture produce and traceability of products in India, moreover APEDA and GS1 India provides agriculture information and continuously trying on development of web-based traceability system in India. Figure 3.1 illustrates the advancement of dissemination model by adopting emerging GS1 standard barcode system and demonstrates the use of web-based traceability technique to disseminate information and tries to establish a new system in the farming community for their produce. Table 3.2 provides the summary on the analysis of costing which is required to develop flexible and comprehensive service that suits all user needs. But 
with rapid development of new technologies such as internet of things and big data a new technique will be emerged in future.

Section 3.1 discusses the necessity of traceability in the Indian food industry and inconsistency in food monitoring system which has given rise to unsafe food, food fraud, scam and adulteration. All these malpractices are taking place in large cities where street vendor, unorganized sector, and open market are situated at large extent, and this was supported by another study conducted by authors(Das, Nagananda, Bhattacharya, \& Bhardwaj, 2010; Lewis, Thompson, Rao, Kalavati, \& Rajanna, 2006; Mahale, Khade, \& Vaidya, 2008; Pokhrel \& Sharma, 2016; Reddi, Kumar, Balakrishna, \& Rao, 2015)in Vishakhapatnam , Guwahati, Bangalore, Hyderabad, Chennai and Mumbai , India. Their finding further highlighted that overcrowded areas, along with uncontrollable open market and unorganized small industries which are mostly non-license holder responsible factor behind inconsistency of food safety and the finding was quite surprising and suggests that local street seller are completely dealt with unsafe food which is sold in public places in many metro cities of India. Overall these findings are also in accordance with findings reported by authors (Pokhrel \& Sharma, 2016; SouzaMonteiro \& Hooker, 2013; WHO, 2015) wherein they have highlighted that Food safety is an essential to protect consumer and society from risk of food poisoning and foodborne diseases and preventing negative impact in food market, similarly in a recent study by Pant et al. (2015) and Kumar et al. (2011) on diary traceability in India found major problems related to dairy supply chain, milk testing and milk safety, and tracking and tracing devices for milk transportation van and barcode on milk package. Thus, traceability and food safety measures are need of the hour which would help to detect the cause and origin of and spread of incident. An effective and controlled food safety system provides a great boost to food industry business and distribution system which help to curtail the spread of unorganized food sector and street seller from market, decease the waste and increases a quality of food products in India.

In chapter 5.1, the adoption of ICT tools for the farming community is discussed in detail and suggest that it is the essential gateway to start the easy traceability management system, and increase productivity(Cebeci et al., 2009), however, table 1.1 provides a summary on current 
PhD Thesis

Keshav Prakash Dandage

Discussions

available ICTs tools in India. This chapter conducts a systematic study review and presents an integrative and comprehensive structure of factors associated with ICT adoption, along with finding the relative barrier for smallholder farmer in result and discussion section 5.1.3. This section highlights several findings from previous work from different countries in past. For instances, Musa et al. (2012) in their review highlighted that socio-economic factors, technical factors, cultural factors and infrastructural support as major challenges in determinants of ICT adoption in small scale farming. Moreover, developed country like Ireland also faces the similar problem of ICT adoption for farming community as recently reported by Wims, P. (2011) in ICTs in IRIS agriculture. An ease of use and broadband access are necessary in rural areas where farms are located though computer access and internet use are high in iris household. Musa et al. (2012) have suggested that low awareness about ICT, traditional way of farming, and lack of contents in local languages, these factors also are equally responsible and need more focus in this area. The finding of this study is also consistent with exiting literature on adoption factors in contexts. For example, internet network in rural areas constraint, which one of the main ICT adoption barrier cited, was also the main barrier cited by (Dhaka \& Chayal, 2016; Obidike, 2011; Wims, 2011; Zhang, Wang, \& Duan, 2016), and other cited barriers were lack of information of ICT from extension officers where farmer community is required an information and training about proper usage of ICT tools from local agriculture officer and agricultural researchers, and adequate electricity supply to run the ICT tools for optimum use, these were also the essential barrier cited by (Dhaka \& Chayal, 2016; Farooq, Muhammad, Chauhdary, \& Ashraf, 2007; Kiplang'at \& Ocholla, 2013; Mittal \& Mehar, 2015; Ovwigho, Ifie, Ajobo, \& Akor, 2009)

In this survey-based study, total 115 respondents including smallholder banana farmer, local trader, and seller from Jalgaon district, India were used as target group. The aim of the study was segmenting likelihood to integrate the use of technology regarding adoption of ICT tools in banana farming and supply chain related activities. This study is different from the studies conducted in Nigeria, Kenya, Tamilnadu, India (Kabunga, Qaim, \& Development, 2011; Nnenna, 2013; Ravichamy, 2014). The present study is similar to the study conducted in Nigeria, Uganda, Kenya. The age group of respondents were in range of $20-50$ years which is similar to 
PhD Thesis

Keshav Prakash Dandage

Discussions

studies conducted in Kenya, Uganda, and Nairobi (Muricho, 2013; Mwombe, Mugivane, Adolwa, \& Nderitu, 2014; Sekabira, Bonabana, \& Asingwire, 2012). (See table 5.2) About $33.7 \%$ farmers are completely agreed that ICT tools are helpful to get information about production and marketing of banana, this results is comparable with studies conducted in Kenya (Sekabira et al., 2012).

Moreover, in result section 5.1.3, it was found that language played crucial part to understand the information provided in ICT and its utilization (see table 5.2). Similar findings on lack of adequate knowledge, lack of infrastructure and language issue about ICT tools have also been reported from different countries, confirming an observation by (Chandra \& Malaya, 2011; Kiplang'at \& Ocholla, 2013; Mittal \& Mehar, 2012; Patil et al., 2008). However, Mittal et al. (2012) have also noted that asymmetric and old information, and lack of use of local language in ICT tools, which has no correlation, and do no work closely with farmers. This study partially agrees with author (Syiem \& Raj, 2015) that use of a particular type of ICT tool depends more on economic condition of farmers and education level. It was the main purpose of the paper to draw attention on utilization of ICT tools by local smallholder farmers, trader and seller; and the present government and private institutes need to establish the ICT informatics center in every district of India by focusing over farmer needs, local language, demand of particular areas and the upcoming problems in adopting the ICT, then obviously this would help the farmers and increase the use of ICTs amongst the farming community to large extent.

In chapter 5.2, the study was conducted on web-based traceability portal for smallholder farmers and other supply chain actors. An exchange of standardized data using cloud and web API that helps food manufacturers to manage products independently, add value to products, provides system to promote food traceability and reduce food and safety incidents was studied, as shown in section 5.2.2, material and methods. In addition, many other researchers from different countries such as (Bechini, Cimino, Marcelloni, \& Tomasi, 2008; Morreale, Puccio, Maiden, Molina, \& Rosines Garcia, 2011; Pizzuti, Mirabelli, Gómez-gonzález, \& Sanz-bobi, 2012; Thakur, Sørensen, Bjørnson, Forås, \& Hurburgh, 2011) have also discussed the potential benefit and necessity of web based traceability system, and (Chi-Chung, 2015; Choe, Park, Chung, \& 
PhD Thesis

Keshav Prakash Dandage

Discussions

Moon, 2009; Yeung, 2011) presented an example of some countries such as Australia, South Korea and Taiwan, where this kind of technology is working regularly, and it provides detailed information on food safety and food quality to all actors of food chain, including consumers through the internet.

Recently many articles have been published on farming product traceability system which suggests many ways to developing food traceability system and collection of data using tools such as barcode, RFID, wireless sensor network, GIS, GPS, and remote sensing. For example, traceability data management for food chains (Folinas, Manikas, \& Manos, 2006), value creation from a food traceability system based on a hierarchical model of consumer personality traits (Chang, Tseng, \& Chu, 2013), RFID web based info-tracing system for artisanal Italian cheese quality traceability (Papetti et al., 2012), RFID enabled traceability system for supply chain of live fish used on web based system for farmers and consumers (Hsu, Chen, \& Wang, 2008), A practical web based tracking and traceability information system for pork products supply chain (Hai et al., 2007), traceability system for tilapia breeding quality safety information based on web using global unified identification EAN-UCC system (Ren, Fu, Mu, Chinese, \& 2009, 2009), and Modeling of web based Food Traceability System for frozen Vegetables(Pizzuti et al., 2012).The main contribution of this paper lies in the introduction of a novel approach using web based solution to business control in supply chain. This is based on reports that are real time and remotely connected to real products which provides rich representation of products and its context, a second contribution of the paper is related to the proposed information systems architecture, which is based on web API platform (See figure 5.7).

\subsection{Implementation of Food Traceability System in India}

Implementation of food traceability is a complex and involves many different aspects which either benefits or affects the internal processes of company and supply chain. In chapter 3, State of art, examines the present traceability techniques in Indian market and the development of the current situation of India in terms of new technology. Furthermore it was found that India is lag behind in research on food traceability. Other authors have observed that lack of proper 
PhD Thesis

Keshav Prakash Dandage

Discussions

coordination between firms and its suppliers, actors, and consumers within network, due to high number of small and medium industries, which creates low consistency along with low awareness (Prahalad, C. K., \& Ramaswamy, 2004). However, Bonney et al (2007) have suggested that continuous improvement is required in Research and Development (R\&D) and New Product Development (NPD) of firm, but it's very difficult for small scale food industries where food cost is already very low, to install the traceability system because of high installation costs of data server, RFID tags, barcodes and readers; a similar conclusion was reached when estimated cost for Indian traceability system was calculated and analyzed in table 3.2 in section 3.4 of this study. Similarly, others have also shown that high upfront cost of investment into traceability, and difficulty of assessing its long term financial benefits especially for small scale industry that minimizes the potential acceptance of traceability system (Gotel \& Mäder, 2012; Ingram \& Riddle, 2013; Karlsen \& Olsen, 2016; Regattieri, Gamberi, \& Manzini, 2007).This result of this study is also consistent with other recent studies of traceability costing and its benefits, along with these previous study have suggested that a simple, low cost, limited sets of data and effective methods improve the transparency in traceability, and are always beneficial and easy to implement the traceability system in food industry (Gotel \& Mäder, 2012; Karlsen \& Olsen, 2016; Regattieri et al., 2007). However published evidence also pointed to likely impact of improved management and tracking of the items within company using technologies like barcode and RFID tagging which are less expensive (Badia-Melis, Mishra, \& Ruiz-García, 2015; Mc Inerney, Corkery, Ayalew, Ward, \& Mc Donnell, 2010; Ruiz-Garcia \& Lunadei, 2011). However, it largely depends on the food operators to change and adopt new practices and facilitate innovative ways to capture and scale up business by incorporating and acquiring more cost-effective practices and equipment.

Under chapter 3, necessity of traceability in the Indian food industry, where extensively focused has put on the todays food waste issues and which is the biggest problem. Apart from financial implications, wasted foods are impacted on social and environmental issues. The food supply chain is main driving force and probably the possibly way in reducing waste and increasing reasonable trade in market. In line with previous studies reveal and suggest that food supply 
chain system supports, benefits and manages their participants like manufacturers, logistics providers, retailers, and intermodal transportation, by using new form of technology like ICT, IoT and Blockchain, which gives right location and real time information of products, and thus, it helps to increase food trade, food safety, and reducing waste material (Liljestrand, 2016; Silander Hagström \& Carlström, 2017). Moreover, in section 3.3, initiatives of traceability system in India, a new model is built which is traceability implementation model and it is based on a brief review of research literature on APEDA and GS1 India Standards (See Figure 3.1). This model provides a more systematic and comprehensive framework to understand the food traceability system in India. Based on this new model, it proposes several directions for research on improving the quality of food products and illustrates the potential applicability of this finding (hypothetical).

Farmer Trading gateway through Direct and Stepwise process in India is described in chapter 5.2, Farmer Profitability: Managing Risk in Agriculture Supply Chain in India (See figure 5.5). This study has shown that there are several real options for farmers to sell their produce without depending upon broker, intermediaries or third party market, and this direct trading gateway makes farmer independent entity which in turn would help to increase market efficiencies, and long run profits of farmers. However, this study is consistent with previous research suggesting that current market requires more indigenous and foreign investment to develop organized retail market where farmers are able to supply their products directly to retailer and consumers(Roy \& Kumar, 2012). In addition, significant result of this study consistent with other studies in this area where direct linking of small farmers to market, traders, exporters, manufacturer raises income of farmers, secure market at agreed price, and ensure trust (Praveen, K.V, 2014). Besides this, previous studies have focused on inter relationship or interdependency between farmers and suppliers and other actors, agro food supply chain management, market place for agriculture products, and contract farming along with private sector initiatives, rather than just focusing over independent farmer market (Ascione, Cristiano, \& Tarangioli, 2011; Kumar, Agrawal, \& Sharma, 2013; Mani, Agrawal, \& Sharma, 2015; Somashekhar, Raju, \& Patil, 2014). With regard to agro food supply chain context, this study has found relative advantage, and has 
highlighted the need for smallholder farmers to be aware of the relative advantage of direct trading gateway instead of stepwise process. However, more in-depth research is required on small scale farmers with regard to the adoption of traceability system in India. 


\section{Chapter 7}

\section{Final Conclusions}

A major outcome of this research study is that provides a better understanding of the food traceability information which is useful for small scale food operators and unorganized food sectors which is distributed in tremendous amount in India. Besides this, it provides the information from government websites and international websites such as APEDA, GS1 India, and FSSAI food portal, along with previously published articles to establish precise food traceability system and standards. Ideally, these findings are replicated in a study where small and large-scale food operator have worked on issues related to food security and food safety which protects an endangered product and limit the illicit trade in business and marketplace across nation.

On the evaluation of current traceability systems in India and assesses the level of adoption of ICT in rural India.

The traceability and ICTs initiatives undertaken by APEDA has revolutionized the agricultural sector in India. APEDA and GS1 India supports food industry and regulates the information flow for management of food supply chain networks in India. The presents traceability systems in India include RFID for livestock, Holograms for food products, Barcode system for horticulture produces in the form of Grapenet, Anarnet and Hortinet using APEDA and GS1 India. 
Information technology has thus impacted rural India and is playing a significant role in growth of agricultural in general and rural development in particular. However, there is a need to take more initiatives to increase the use of these technologies by the farming community, particularly among the small holder farmers for effective and efficient implementation of ICT initiatives. Although, Indian farming sector is mainly occupied by small and marginal farmers, the study revealed that they still rely more on traditional methods of production and this affects the level of productivity and food safety. Thus, the study reveals that rural development in terms of traceability system and ICT initiatives shared by all sections of the farmers in rural areas has not yet taken place in India.

Beside this, although food regulator, Food Safety and Standards Authority of India (FSSAI) is taking stern steps to enforce its norms, the consumption of unorganized packaged food sector has increased in India. The study reveals that consumers in India still have a traditional food shopping habit. This has led to the increase in homegrown business in India. Poorly packaged unbranded food products are widely sold in kirana stores across Indian cities and this necessitates the implementation of stringent norms to achieve the food safety standards of the country. Utility and effective implementation of ICTs in rural areas needs to be deeply studied to make supply chain more efficient and effective. There is a need for large scale investment from government and private players to achieve the highest level of traceability and ICT adoption in the country in general and rural areas in particular.

\section{On the adoption level of ICT initiatives among the small holder banana farmers in Jalgaon district of India.}

The findings of the survey revealed that the small holder banana farmers in the survey area still applied traditional farm practices in the banana production and distribution. Most of these farmers had little knowledge about the existing services and latest ICT initiatives in agricultural sector. Most of the farmers were of the opinion that basic ICT tools like radio, newspapers, television and simple mobile phones were most useful tools to access information related to farming. The least accessible ICTs tools according to them were computer, and web-based services like internet connectivity and other value-added services 
including email search, internet search and social networking. It was also found that the older generation of these small holder banana farmers were completely unaware of the existing modern ICT technologies, while the younger generation with some basic level of education were of the opinion that ICT tools would be beneficial in getting information related agriculture and increase their income. However, poor access of internet in field area, lack of electricity and low level of education among farmers groups were found to be the most constraining factor to the use of ICT tools by them.

It was also found that language of these ICT tools has also influenced the adoption of ICTs both by the farmers and traders in the survey area. Most of the farmers and traders wanted ICT tools to be in native language which according to them would help them better understand the information available. Other constraints that influence the use of ICT tools were; lack of ICT skills, lack of ICT infrastructure (High speed internet connectivity), fear and distrust of technology and cost involved in the use of ICTs. Low profiled group of farmers are not able to pay their monthly mobile bills or to recharge their prepaid connection due to high cost of voice and text messages, as well as language of the mobile handsets and text messages are different which is creating many barriers for farmers in India.

Therefore, the result of the study suggest that adoption level of the ICTs should be enhanced by taking cognizance of these unmet needs of small holder farmers and develop market led business model which would increase the productivity and alleviate the current status of small holder banana farmers in India. For this more ICT kiosks should be set up in every village with internet facility.

\section{On supporting local food systems in India and direct sourcing of raw material from farmers to customer, retailer, food business operator, and exporter in India}

It was revealed during the survey that small and marginal farmers face difficulty in marketing their produce. Farmers are compelled to sell their produce in open market (Mandi). Though it is government regulated there are number of intermediaries in the supply chain who decide the price of the commodities. The farmers are compelled to sell at whatever price is decided 
by these intermediaries. Besides this, during the peak season, the farmers have to wait for many days to get their produce unloaded. Moreover, these mandis exhibit lack of basic marketing infrastructure such as grading, standardization and storage facilities and this deteriorates the quality of the produce. Apart from this, it was also noticed that villages where the present study was conducted do not have proper roads. Although trucks are generally used in transporting their produce to the market, the cost of transportation is generally very high as a result, the farmers get very low return on their output.

To mitigate the problems faced by the farmers in the supply chain, the present study supports the direct sourcing of raw material from farmers to customer, retailer, food business operator, and exporter in India. In this process the farmer develops direct contact with the trading actors like manufacturer, exporter, distributor, retailer, and consumer/end user on the basis of quality products. Thus, farmers can directly get connected with trading actors and consumers without intermediaries and broker. This would be facilitated by ICT application which has the potential to solve the problems related to the agricultural supply chain by offering a communication platform which links farmers to the markets. Several companies such as Reliance industries, Bharati Group, Aditya Birla Group, Godrej group, Future group, and Tata sons and global retailing majors including Wal-Mart, metro cash and carry to UK's Bookers group have entered the market which has brought some changes in the supply chain of food products. Yet the food retail industry in India has failed to make any impact on the market and lot need to be done more improvement in the present scenario.

Information communication technologies (ICTs) thus, help in reduction of transportation costs, reduce information-based service cost, reduce market search cost, facilitate track and traceability system, market fairness, increase customer satisfaction and increase the profit margin of farmers. In short, ICT would help to raise the income level of small and marginal farmers who are facing problems in the current scenario uneven modernization of markets which is taking place in the country where large-scale farmers are increasingly being preserved while and small and medium farmers are losing their share rapidly. 


\section{On providing market facility at farm gate to farmers to increase their net income through web-based traceability portal in India}

Smallholder farmers, who are the focus of this study, play a key role in meeting the food demands of increasing population of the country. However, small-holder farmers are facing many constraints due to which they are not able to adopt sophisticated farm practices and undertake the necessary measures to meet food quality and safety requirements. The research findings showed that these farmers have limited access to the markets both for inputs and outputs, and this is affecting their production activities. Most of the small holder farms in the survey areas had low profit margins which limited their access to productivity-enhancing technologies. Besides this, their productivity is also affected by lack of education, which could help build the skills needed to manage new productive techniques and improve their market performance.

The small and marginal farmers thus, face difficulty to cope with the waves of changes taking place in food market and farming system of the country. To address these challenges, the present study endeavors to create a web-based traceability portal to establish direct link between the farmer and the market and help farmers to improve their productivity and at the same time address the food safety concerns of the country. Farm direct marketing is a longheld need of the farmers and consumers of the country and would ensure higher profitability to the small-scale farmers and meet the satisfaction level of the consumers through the direct sale of the agricultural commodity at affordable price. Direct marketing of agricultural produce would eliminate middle men and commission agents who charge high commission fees from the framers and this in turn would help farmers increase their net income and improve their living standards.

At present days, many developed countries have supported to traceability system and mandated in its production process and supply chain. Food safety and quality of food indeed, both are essential for consumer and with the support of traceability system, authenticity and reliable information are easily obtained and preserve or protect the genuineness of raw 
material or a processed product. From the viewpoint of food traceability, the food business, supplier, retailer is almost managed to provide the good quality of food to consumers, as well as it has increased food safety and consumer base which helps to monitor and defend against external threats coupled with internal threats in real time. However, accessible information, smart infrastructure facility, and food regulations might be considered a promising aspect of establishing the comprehensive traceability in the workplace, but devoid of these factors that convert into obstacles in achieving traceability standards and effective traceability system. Summing up the results of this study, it can be concluded that in conjunction with mandatory FSSAI regulation, QCIN Certification, and BIS standards like FSSAI License or Registration, IndiaHACCP, IndiaGHP, IS/ISO $22000: 2005$, and IS/ISO $22005:$ 2007/ISO 22005: 2007 respectively would help the organizations to manage food safety hazards and these food safety tools need to further explore the opportunities for the participation by all the stakeholders in food supply chain and create space for accessible, acceptable and appropriate traceability system which can be used for complying with international market requirements

The main aim of the traceability portal is to provide fast, reliable, efficient services to the farmer, trader, supplier and other actors of supply chain. With the help of this portal, the user like consumer, retailer, manufacturer, exporter, food business entrepreneurs and other supply chain actors would get access to the global registry of farmers from UIDAI (unique Identification Authority of India) for proof of national identification card, farm location information using GLN (Global Location Number) from GS1 India, soil nutrients information from Soil health card, Residual analysis report of farm produces using Indian food laboratory network (InfoLNet) from FSSAI, and lastly the grading and quality certification of raw materials from AGMARK. Thus, with the help of global registry of farmers it would develop food security and sustainability, at the same time it provides an easy access to the consumers, retailers, manufactures and other actors involved in supply chain who would get the complete history of the farmer from the same place and at the same time and help to build mutual trust between the farmers and other actors. 
The findings of the present study are very convincing since and draws the following conclusion: that integration of IOT, information and communications technologies (ICTs), cloud database with food supply chain and traceability enables food businesses to enhance accuracy, monitoring and reliability, sustainability, product optimization, chain communication and most essential part is time savings and avoiding food recalling in particular area. Existing ICT systems, including Communications technology (conferences, email, mobile phones, printed materials, telecommunications, telephones), and Information and communication technologies (RFID technology, Barcode technology, sensing technology, GIS and GPS, internet, mobile phones, websites, web conferencing, cloud database and API connectivity, e-commerce and e-tailoring systems) are useful to connect and present the product in global market.

Thus, there are lots of benefits which come along with traceability as highlighted. Still, this study suggests that there is possibility to achieve effective traceability system in India. This makes the study is quite 'different' to say the least since it went more in-depth than one would think. It has discovered that food traceability system can be easily established in Indian food industry and for this it only needs to guide and integrate an existing system into coordinated form and it also appears that government and private firms need to work together. The proposed schematic framework in chapters 3 and 5, have also concluded that if these both models worked together (See figures 3.1 and 5.7), then very cost-effective food traceability system can be developed and the proposed method can be readily used in practice. Still, future research is needed to improve knowledge and technology for developing better elasticity in the areas of web-based traceability system in India.

The present scenario of internet connectivity in rural areas is fast changing and many companies are offering multiple-channel internet facility leading to the social and economic growth of the remote areas in India. These changes are great incentives for the application of this web-based portal in the rural areas which would help small scale farmers to produce quality product and improve their market performance and in turn improve their livelihoods. 


\section{Chapter 8}

\section{Suggestions for future research}

In order to address the challenges identified around the need for better improvement in the current policies and developing robust transforming food traceability system with help of ICT tools in a marketplace for local and small-scale food producers.

1. Guidance for small-scale food producers on internal control and development of effective risk management in place where most activities are performed;

To enable effective business management by local and small-scale food producer integrate compliance with national food policies.

To enable effective supply chain, identification of new technologies, comprehensive procedures policies, and protocols all need to be integrated with their producer, supplier, distributors and retailers.

2. Improve information and communication technology tools. Making them more are upto-date, user-friendly and well adapted to the farming sector, food production and distribution systems;

With help of ICTs in farming sector, transformative and innovative solutions could bring for poorest farmer and family, for example, information about climate, accessing to marketplaces, 
crop and land selection, agriculture extension and advisory services, and latest rates of inputs such as fertilizers and seeds.

With help of ICTs in the food sector, the operational costs could be reduced, along with it has improved performance, firm efficiency and the operational costs, the supply chain management. ICT has increased understanding and good relationship with external factors such as supplier, logistics provider, distributor and retailers.

3. Increase awareness of ways to use and access product traceability information using digital technology;

In terms of lowering down the products counterfeit, product recalling, and contamination from market on base of digital technology like RFID and barcodes

In terms of mapping, easily accessible of product information, and food safety and security.

\section{Installation and development of the public web server and cloud server while providing unprecedented access with upfront performances;}

To increase more transparency in the system and easy communication between consumer and business.

To increase more secure food business and involvement of local farmers as a raw material supplier rather than intermediaries, hence digital database and servers are necessary to access information at high speed.

Distribution of database and web API accessible for public use, with the help of this easy going web API system, public and private entities can develop the transparent farmer's product traceability system in future. 


\section{References:}

AgCensus. (2011). Highlights of Agriculture Census 2010-11. Retrieved from http://pib.nic.in/newsite/PrintRelease.aspx?relid=132799

Amazon. (2006). What is Cloud Computing? - Amazon Web Services. Retrieved from https://aws.amazon.com/what-is-cloud-computing/?nc1=f_cc

Arjun, K. M. (2013). Indian Agriculture- Status, Importance and Role in Indian Economy. International Journal of Agriculture and Food Science Technology, 4(4), 343-346. Retrieved from http://www.ripublication.com/

Arunkumar K R. (2010). Mobile Agriculture, eAgriculture, ICT, M-Agriculture. Retrieved from https://www.slideshare.net/arunkumarss/mobile-eagriculture

Ascione, E., Cristiano, S., \& Tarangioli, S. (2011). Farm Advisory Services for the Agro-Food Supply Chain as a Foster of Innovation: The Case of Veneto Region. Proceedings in Food System Dynamics, O(0), 447-461. https://doi.org/10.18461/pfsd.2011.1134

Aung, M. M., \& Chang, Y. S. (2014). Traceability in a food supply chain: Safety and quality perspectives. Food Control. https://doi.org/10.1016/j.foodcont.2013.11.007

Azevedo, E. De. (2015). O Ativismo Alimentar Na Perspectiva Do Locavorismo. Ambiente \& Sociedade, 18(3), 81-98. https://doi.org/10.1590/1809-4422ASOC740V1832015

Badia-Melis, R., Mishra, P., \& Ruiz-García, L. (2015). Food traceability: New trends and recent advances. A review. Food Control, 57, 393-401. https://doi.org/10.1016/j.foodcont.2015.05.005

Banerjee, A. (2011), the Ict in Agricutture : Bridging Bharat With India. Global Media Journal Indian Edition, 2(2), 1-16. Retrieved from https://caluniv.ac.in/global-mdia-journal/Winter Issue December 2011 Students' Research/SR-4.pdf

Bechini, A., Cimino, M. G. C. A., Marcelloni, F., \& Tomasi, A. (2008). Patterns and technologies for enabling supply chain traceability through collaborative e-business. Information and Software Technology, 50(4), 342-359. 
https://doi.org/10.1016/j.infsof.2007.02.017

Bhat, R. V, Science, C. F., Food, E., \& Problems, S. (2005). New Policy and Programme To Ensure Food Safety in, 1-10. Retrieved from http://nutritionfoundationofindia.res.in/NNP/proceeding/Dr-Bhat.pdf

Birthal, P., And, P. R.-A. D. in I. P., \& 2011, U. (2011). Farmers to Markets in the Changing Agricultural Scenario. Books.google.com. Retrieved from https://books.google.com/books?hl=en\&lr=\&id=1J3kLmjjnw0C\&oi=fnd\&pg=PA159\&dq= ++ Farmers + to + Markets + in + the + Changing + Agricultural + Scenario\&ots=DTTRKms_PA\&si $\mathrm{g}=\mathrm{V} 1 \mathrm{xK}-\mathrm{hktc} 1 \mathrm{C} 2 \mathrm{q} 0 \mathrm{KS} 44 \mathrm{~B} 0 \mathrm{rTDBNaA}$

BIS. (2015). Indian Standards Locater. Retrieved from http://164.100.105.199:8071/php/BIS/IndStndrdLocatr/SubSubGroupStndrds.php?SubGId= 18

Boomi. (2015). Personal Computer Companies; Dell Boomi API Management Makes It Easier and More Cost Effective to Create, Publish and Manage APIs. Information Technology Newsweekly, 73. Retrieved from https://boomi.com/press-releases/dell-boomi-apimanagement-makes-easier-cost-effective-create-publish-manage-apis/

Bowling, A. (2002). Research Methods in Health: Investigating health and health services. Retrieved from https://trove.nla.gov.au/work/17693852?q\&versionId=27474148

Budde, M. E., Rowland, J., \& Funk, C. C. (2010). Agriculture and food availability -- remote sensing of agriculture for food security monitoring in the developing world. Earthzine. Retrieved from https://pubs.er.usgs.gov/publication/70042397

Bureau, B. B. (2016). India: An agricultural powerhouse of the world. Business Standard India, 2017. Retrieved from http://www.business-standard.com/article/b2b-connect/india-anagricultural-powerhouse-of-the-world-116051800253_1.html

Cebeci, Z., Erdogan, Y., Alemdar, T., Celik, L., Boga, M., Uzun, Y., ... Tösten, F. (2009). An ICT-based traceability system in compound feed industry. Main. Retrieved from http://ageconsearch.umn.edu/bitstream/53569/2/11_Zeynel_Apstract.pdf

CensusIndia. (2016). Census of India: Administrative Units. Retrieved from http://censusindia.gov.in/Tables_Published/Admin_Units/admin.html

Chand, R., Prasanna, P. a L., \& Singh, A. (2011). Farm size and productivity: Understanding the strengths of smallholders and improving their livelihoods. Economic \& Political Weekly, XLVI(26/27), 5-11. https://doi.org/10.2307/23018813

Chandra, D. G., \& Malaya, D. B. (2011). Role of e-Agriculture in Rural Development in Indian Context. Emerging Trends in Networks and Computer Communications (ETNCC), 2011 International Conference on, (APRIL 2011), 320-323. https://doi.org/10.1109/ETNCC.2011.6255913

Chang, A., Tseng, C.-H., \& Chu, M. (2013). Value creation from a food traceability system based on a hierarchical model of consumer personality traits. British Food Journal, 115(9), 1361-1380. https://doi.org/10.1108/BFJ-11-2011-0286 
Chi-Chung, N. (2015). Adopting the Food Traceability System in Vietnamese agriculture: Effects on Purchase intention, Price premium and Loyalty. Retrieved from http://thesis.topcoglobal.com/TopcoTRC/2015_Thesis/R0027.pdf

Choe, Y. C., Park, J., Chung, M., \& Moon, J. (2009). Effect of the food traceability system for building trust: Price premium and buying behavior. In Information Systems Frontiers (Vol. 11, pp. 167-179). https://doi.org/10.1007/s10796-008-9134-z

Dandage, K., Badia-Melis, R., \& Ruiz-García, L. (2017, January 1). Indian perspective in food traceability: A review. Food Control. Elsevier Ltd.

Das, A., Nagananda, G. S., Bhattacharya, S., \& Bhardwaj, S. (2010). Microbiological quality of street-vended indian chaats sold in bangalore. Journal of Biological Sciences, 10(3), 255260. https://doi.org/10.3923/jbs.2010.255.260

Dhaka, B. L., \& Chayal, K. (2016). Farmers' Experience with ICTs on Transfer of Technology in Changing Agri-rural Environment. Indian Res. J. Ext. Edu, 10(3), 114-118.

DoT. (2015). Report of the Committee on National Optical Fibre Network (NOFN). Retrieved from http://www.dot.gov.in/sites/default/files/Report of the Committee on NOFN.pdf

eGovtIndia. (2014). About m-Govworld —. Retrieved from http://www.mgovworld.org/aboutm-govworld

Faisal, M. N., \& Talib, F. (2016). Implementing traceability in Indian food-supply chains: An interpretive structural modeling approach. Journal of Foodservice Business Research, 19(2), 171-196. https://doi.org/10.1080/15378020.2016.1159894

FAO. (2003). Assuring Food Safety And Quality: Guidelines For Strengthening National Food Control Systems. Retrieved from http://www.fao.org/3/a-y8705e.pdf

FAO. (2011). The State of food insecurity in the world 2011. What does international proce volatility affect domestic economies and food security? Retrieved from http://www.fao.org/catalog/inter-e.htm

FAOSTAT. (2016). FAOSTAT. Retrieved from http://www.fao.org/faostat/en/\#data/QC/visualize

Farooq, S., Muhammad, S., Chauhdary, K. M., \& Ashraf, I. (2007). Role of Print Media in the Dissemination of Agricultural Information Among Farmers. Pakistan Journal of Agricultural Science, 44(2), 378-380.

Folinas, D., Manikas, I., \& Manos, B. (2006). Traceability data management for food chains. British Food Journal, 108(8), 622-633. https://doi.org/10.1108/00070700610682319

FoSCoRIS. (2017). FoSCoRIS. Retrieved from https://foscoris.fssai.gov.in/

FSSAI. (2017). Introduction. Retrieved from http://fssai.gov.in/home/fsslegislation/introduction.html

FSSAI_FRP. (2017). Food Regulatory Portal - One Nation, One Food Law. Retrieved from $\mathrm{http}: / /$ foodregulatory.fssai.gov.in/index 
FSSAI_INFoLNET. (2017). FSSAI | INFoLNET. Retrieved from https://infolnet.fssai.gov.in/\#/

FSSAI_WFI. (2017). World Food India 2017. Retrieved from http://fssai.gov.in/home/Events/World-Food-India-2017.html

Gartner. (2014). Which New and Old Applications Will Enable Digital Business? Retrieved from https://www.gartner.com/doc/2831022/new-old-applications-enable-digital

Gartner. (2016). Gartner Says Worldwide Public Cloud Services Market Is Forecast to Reach \$204 Billion in 2016. Retrieved from https://www.gartner.com/newsroom/id/3592917

GoI. (2016a). FM: Key challenges faced by the Indian agriculture include the need to increase productivity by leveraging technology-especially for high yielding and resistant variety seeds, efficient utilization of water, adaption of latest IT to increase resilience to. Retrieved from http://pib.nic.in/newsite/PrintRelease.aspx?relid=134157

GoI. (2016b). Government of India Profile | National Portal of India. Retrieved from https://www.india.gov.in/topics/agriculture

Gotel, O., \& Mäder, P. (2012). Acquiring tool support for traceability. In Software and Systems Traceability (Vol. 9781447122, pp. 43-68). https://doi.org/10.1007/978-1-4471-2239-5_3

Grove, S. K., Burns, N., \& Hegstad, L. N. (1997). The practice of nursing research; conduct, critique and utilization. 2nd ed. Saunders. Retrieved from https://books.google.es/books/about/The_Practice_of_Nursing_Research.html?id=MaKwAi kiobkC\&redir_esc $=\mathrm{y}$

Hai, X. Ben, Qing-Yao, L., Liang, Y., Run-Ting, F., Zhao-Hui, L., \& Jia-Rong, P. (2007). A practical web-based tracking and traceability information system for the pork products supply chain. New Zealand Journal of Agricultural Research, 50(5), 725-733. https://doi.org/10.1080/00288230709510344

Hong, P. J. W. (2014). Shaping the Future with ICT Convergence. Retrieved from http://dpnm.postech.ac.kr/publications/abstract/MS20152

Hsu, Y. C., Chen, A. P., \& Wang, C. H. (2008). A RFID-enabled traceability system for the supply chain of live fish. In Proceedings of the IEEE International Conference on Automation and Logistics, ICAL 2008 (pp. 81-86). https://doi.org/10.1109/ICAL.2008.4636124

IBEF. (2014). Indian Food Industry, Food Processing Industry in India, Statistics. Ibef. Retrieved from https://www.ibef.org/industry/indian-food-industry.aspx

IBM. (2016). The API Economy - API Connect. Retrieved from https://developer.ibm.com/apiconnect/docs/the-api-economy/

India Brand Equity Foundation. (2017). Agriculture in India: Industry Overview, Market Size, Role in Development...| IBEF. Retrieved from https://www.ibef.org/industry/agricultureindia.aspx

Ingram, C., \& Riddle, S. (2013). Cost-benefits of traceability. In Software and Systems Traceability (Vol. 9781447122, pp. 23-42). https://doi.org/10.1007/978-1-4471-2239-5_2 
Jaspreet, A. (2015). Use of ICTs in Indian Agriculture | FAO. Retrieved from $\mathrm{http}: / / \mathrm{www}$.fao.org/family-farming/detail/en/c/417267/

Jeff Hawn. (2015). Agricultural IoT promises to reshape farming. Retrieved from https://www.rcrwireless.com/20151111/internet-of-things/agricultural-internet-of-thingspromises-to-reshape-farming-tag 15

Kabunga, N., Qaim, M., \& Development, R. (2011). Knowledge Asymmetries and Technology Adoption: The Case of Tissue Culture Bananas in Kenya. Development, (April). Retrieved from https://www.econstor.eu/handle/10419/90476

Kalsi, N. S., Kiran, R., \& Vaidya, S. C. (2009). Effective e-Governance for Good Governance in India. International Review of Business Research Papers, 5(1), 212-229.

Kameswari, V. (2011). Agricultural Policy, ICTS and Market Participation of Farmers in the Indian Himalayan Region. ICTS and Market Participation of Farmers in the ..., 1-14. Retrieved from http://papers.ssrn.com/sol3/papers.cfm?abstract_id=1976183

Karlsen, K. M., \& Olsen, P. (2016). Problems and Implementation Hurdles in Food Traceability. In Advances in Food Traceability Techniques and Technologies: Improving Quality Throughout the Food Chain (pp. 35-46). https://doi.org/10.1016/B978-0-08-1003107.00003-X

Kemp, S. (2015). Digital, social and mobile in 2015 : Executive summary. Zenithmalaysia.com. Retrieved from http://zenithmalaysia.com/infobank/Digital_social_and_mobile_in_2015_Executive_summa ry.pdf

Kesterton, A. J., Cleland, J., Sloggett, A., \& Ronsmans, C. (2010). Institutional delivery in rural India: The relative importance of accessibility and economic status. BMC Pregnancy and Childbirth, 10. https://doi.org/10.1186/1471-2393-10-30

Kiplang'at, J., \& Ocholla, D. N. (2013). Diffusion of Information and Communication Technologies in communication of agricultural information among agricultural researchers and extension workers in Kenya. South African Journal of Libraries and Information Science, 71(3). https://doi.org/10.7553/71-3-591

Kokate, K., \& Singh, A. (2013). Use of Mobile Technologies for Empowering Small holder farmers in India. Http://www.e-Agriculture.org/content/use-Mobile-TechnologiesEmpowering-Small-Holder-Farmers-India (Accessed 2 June 2014), 1-9. Retrieved from $\mathrm{http}: / /$ satnetasia.org/sites/default/files/6-Mobile_extension_empowering_smallholderICAR_India_paper.pdf

Krishna Reddy, P., \& Ankaiah, R. (2005). A framework of information technology-based agriculture information dissemination system to improve crop productivity. Current Science, 88(12), 1905-1913.

Kumar, R., Agrawal, R., \& Sharma, V. (2013). e-Applications in Indian Agri-Food Supply Chain: Relationship among Enablers. Global Business Review, 14(4), 711-727. https://doi.org/10.1177/0972150913501610 
Lewis, J. E., Thompson, P., Rao, B., Kalavati, C., \& Rajanna, B. (2006). Human Bacteria in Street Vended Fruit Juices : A Case Study of Visakhapatnam City, India. Researchgate.net, $8,35-38$. Retrieved from https://www.researchgate.net/profile/Kalavati_Chaganti/publication/237392218_Human_Ba cteria_in_Street_Vended_Fruit_Juices_A_Case_Study_of_Visakhapatnam_City_India/links /0deec52a5f4094 $29 \mathrm{ca000000/Human-Bacteria- \overline {in } - S t r e e t - V e n d e d - F r u i t - J u i c e s - A - C a s e - ~}$ Study-of-

Liljestrand, K. (2016). Reducing the environmental impact of food products logistics systems. Chalmers University of Technology. Retrieved from http://publications.lib.chalmers.se/publication/245227-reducing-the-environmental-impactof-food-products-logistics-systems

Lipton, M. (2004). New directions for agriculture in reducing poverty: the DFID initiative. Poverty Research Unit, University of Sussex, Brighton, UKton. html]. Retrieved from https://www.researchgate.net/profile/Michael_Lipton/publication/228464453_New_directio ns_for_agriculture_in_reducing_poverty_the_DFID_initiative/links $/ 0046352 \mathrm{~d} 2695 \mathrm{ede} 03 \mathrm{c} 0$ 00000.pdf

Lowder, S. K., Skoet, J., \& Raney, T. (2016). The Number, Size, and Distribution of Farms, Smallholder Farms, and Family Farms Worldwide. World Development, 87, 16-29. https://doi.org/10.1016/j.worlddev.2015.10.041

Madhusudhan, L. (2015). Agriculture Role on Indian Economy. AstonJournals. Retrieved from https://scholar.google.com/scholar?hl=en\&as_sdt=0\%2C5\&scioq=Agriculture+Role + on + In dian + Economy\&scilib $=1 \& q=$ Madhusudhan $\% 2 \mathrm{C}+$ L. $+2015 .+$ Agriculture + Role + on + Indian + Economy.+Business + and + Economics + Journal\&btnG $=$

Madon, S. (2004). Evaluating the developmental impact of e-governance initiatives: an explanatory framework. The Electronic Journal on Information Systems in Developing Countries, 20(5), 1-13. https://doi.org/10.1162/itid.2007.4.1.19

MahaAgri. (2016). Projects and Plans: CDAP - Jalgaon. Retrieved from $\mathrm{http}: / / \mathrm{www}$. mahaagri.gov.in/level3PdfDisp.aspx? $\mathrm{Id}=5 \&$ subid $=15 \&$ sub2id $=9 \&$ FileName $=\mathrm{C}$ hapetar-2.pdf

Mahale, D. P., Khade, R. G., \& Vaidya, V. K. (2008). Microbiological Analysis of Street Vended Fruit Juices from Mumbai City , India. Analysis, 10, 31-34. Retrieved from http://www.academia.edu/download/31962798/ijfsv10-5.pdf

Mahendra Dev, S. (2012a). Small Farmers in India: Challenges and Opportunities. Indira Gandhi Institute of Development Research (IGIDR), (June), 2012-14.

Mahendra Dev, S. (2012b). Small Farmers in India: Challenges and Opportunities Small Farmers in India: Challenges and Opportunities Small Farmers in India: Challenges and Opportunities, (June), 2012-14. Retrieved from http://oii.igidr.ac.in:8080/xmlui/handle/2275/262

Mani, V., Agrawal, R., \& Sharma, V. (2015). Social sustainability in the supply chain: analysis of enablers. Management Research Review, 38(9), 1016-1042. 
https://doi.org/10.1108/MRR-02-2014-0037

Mc Inerney, B., Corkery, G., Ayalew, G., Ward, S., \& Mc Donnell, K. (2010). A preliminary in vivo study on the potential application of e-tracking in poultry using ink printed $2 \mathrm{D}$ barcodes. Computers and Electronics in Agriculture, 73(2), 112-117. https://doi.org/10.1016/j.compag.2010.06.004

McEntire, J. C., Arens, S., Bernstein, M., Bugusu, B., Busta, F. F., Cole, M., ... Ohlhorst, S. (2010). Traceability (Product Tracing) in Food Systems: An IFT Report Submitted to the FDA, Volume 1: Technical Aspects and Recommendations. Comprehensive Reviews in Food Science and Food Safety. https://doi.org/10.1111/j.1541-4337.2009.00097.x

Meera, S. N., Jhamtani, A., \& Rao, D. U. M. (2004). Information and Communication Technology in Agricultural Development: A comparative Analysis of Three Projects from India. Agricultural Research \& Extension Network, (135), 2-15. Retrieved from http://dlc.dlib.indiana.edu/dlc/handle/10535/4915

Milne, A. (2013). The rise and success of the barcode: Some lessons for financial services. Journal of Banking Regulation, 14(3-4), 241-254. https://doi.org/10.1057/jbr.2013.16

Ministry of Health and Family Welfare, \& Food Safety and Standards Authority of India. (2016). Food Safety and Standards. Retrieved from http://old.fssai.gov.in/Amendments_Gazettee_Notifications/Amendments_FSS_Regulation _Food_Business_License_Regis.aspx

Mintel. (2017). Global Packaging Trends 2018 | Mintel.com. Retrieved from http://www.mintel.com/global-packaging-trends/

Mitra, S., Bery, S., B, G. D., \& Krishna, R. (2010). The Nature of Rural Infrastructure: Problems and Prospects. Working Papers. Retrieved from https://ideas.repec.org/p/ess/wpaper/id2357.html\#author

Mittal, S., \& Mehar, M. (2012). An assessment of Farmer's information networks and their use in India. AFITA/WCCA 2012 Conference, September. Retrieved from http://www.afita.org/graph/web_structure//files/Seminar (07)-02(1).pdf

Mittal, S., \& Mehar, M. (2015). Socio-economic Factors Affecting Adoption of Modern Information and Communication Technology by Farmers in India: Analysis Using Multivariate Probit Model. The Journal of Agricultural Education and Extension, 8622(September), 1-14. https://doi.org/10.1080/1389224X.2014.997255

mkisan. (2015). Agriculture. Retrieved from http://mkisan.gov.in/downloadmobileapps.aspx

Morreale, V., Puccio, M., Maiden, N., Molina, J., \& Rosines Garcia, F. (2011). The role of service orientation in future web-based food traceability systems. In Food Chain Integrity: A Holistic Approach to Food Traceability, Safety, Quality and Authenticity (pp. 3-22). https://doi.org/10.1016/B978-0-85709-068-3.50001-9

Mulesoft. (2017). API Strategy Resources | MuleSoft. Retrieved from https://www.mulesoft.com/resources/api-strategy 
Muricho, M. (2013). ASSESSMENT OF CONSTRAINTS IN INFORMATION AND COMMUNICATION TECHNOLOGY USE IN BANANA PRODUCTION. Retrieved from http://erepository.uonbi.ac.ke/bitstream/handle/11295/56567/Muricho_constraints in information.pdf?sequence $=1$

Mwombe, S. O. L., Mugivane, F. I., Adolwa, I. S., \& Nderitu, J. H. (2014). Evaluation of Information and Communication Technology Utilization by Small Holder Banana Farmers in Gatanga District, Kenya. Journal of Agricultural Education and Extension, 20(2), 247261. https://doi.org/10.1080/1389224X.2013.788454

National Commission for enterprises in the Unorganised Sector. (2008). A Special Programme for Marginal and Small farmers. Retrieved from http://nceuis.nic.in/Special_Programme_Medium_Small_Farmers.pdf

NHB. (2015). Health at a Glance 2015. https://doi.org/10.1787/health_glance-2015-en

Nnenna, E. A. (2013). Access and application of information and communication technology ( ICT ) among farming households of south east Nigeria. Agriculture and Biology Journal of North America, 4(6), 605-616. https://doi.org/10.5251/abjna.2013.4.6.605.616

NSS. (2003). India - National Sample Survey 2003 (59th round) - Schedule 18.1 - Land and Livestock Holdings. Retrieved from http://catalog.ihsn.org/index.php/catalog/1923

Obidike, N. a. (2011). Rural farmers' problems accessing agricultural information: a case study of Nsukka local government area of Enugu State, Nigeria. Library Philosophy and Practice, (2007).

Olsen, P., \& Borit, M. (2013). How to define traceability. Trends in Food Science and Technology. https://doi.org/10.1016/j.tifs.2012.10.003

Opara, L. U. (2003). Traceability in agriculture and food supply chain: A review of basic concepts, technological implications, and future prospects. Food, Agriculture \& Environment, 1(1). Retrieved from https://pdfs.semanticscholar.org/4f63/2b6ec4bd1 ebdc53a0fcf295b1cd3800ed11e.pdf

Organisation Economic Cooperation Development (OECD). (2014). Competition Issues in the Food Chain Industry (p. 489). Retrieved from https://www.oecd.org/daf/competition/CompetitionIssuesintheFoodChainIndustry.pdf

Ovwigho, B. O., Ifie, P. A., Ajobo, R. T., \& Akor, E. I. (2009). The Availability and Use of Information Communication Technologies by Extension Agents in Delta Agricultural Development Project, Delta State Nigeria. Journal of Human Ecology, 27(3), 185-188. https://doi.org/10.1080/09709274.2009.11906209

Painter, K. (2007). An Analysis of Food-Chain Demand for Differentiated Farm Commodities : Implications for the Farm Sector Report to Ag of the Middle, 3-46. https://doi.org/Report 215

Pakstaite, S. (2015). Bio-Reactive Food Expiry Label. Retrieved from http://www.google.si/patents/US20170082589?hl=sl\&cl=en 
Pal, M. (1992). Land Productivity and Employment in Indian Agriculture: A Case Study of Meerut Region. Mittal Publications. Retrieved from https://books.google.es/books/about/Land_Productivity_and_Employment_in_Indi.html?id $=\mathrm{OF} 18 \mathrm{gh} 40 \mathrm{zgsC} \&$ redir_esc $=\mathrm{y}$

Papetti, P., Costa, C., Antonucci, F., Figorilli, S., Solaini, S., \& Menesatti, P. (2012). A RFID web-based infotracing system for the artisanal Italian cheese quality traceability. Food Control, 27(1), 234-241. https://doi.org/10.1016/j.foodcont.2012.03.025

Patil, V. C., Gelb, E., Maru, A., Yadaraju, N. T., Moni, M., \& Misra, H. (2008). Adoption of Information and Communication Technology (ICT) for Agriculture: An Indian case study. IAALD AFITA World Conference on Agricultural Information and IT, 685-692. Retrieved from http://www.cabi.org/GARA/FullTextPDF/2008/20083298229.pdf

Pen, J. B. (2010). A Symposium Sponsored by The Federal Reserve Bank of Kansas City. Retrieved from https://pdfs.semanticscholar.org/1a7a/19c78539051e42aad72511f8f099120e9ad5.pdf

Piekarczyk, J. (2014). Application of Remote Sensing in Agriculture. Geoinformatica Polonica, 13(1), 69--75. https://doi.org/10.2478/gein-2014-0007

Pizzuti, T., Mirabelli, G., Gómez-gonzález, F., \& Sanz-bobi, M. A. (2012). Modeling of an Agro-Food Traceability System : The Case of the Frozen Vegetables. Proceedings of the 2012 International Conference on Industrial Engineering and Operations Management Istanbul, Turkey, July 3 - 6, 2012 Modeling, 1065-1074.

Pokhrel, P., \& Sharma, D. (2016). A study on assessment of food safety knowledge and practices among the street food vendor of urban and semi urban areas of Guwahati , Assam. International Journal of Home Science, 2(2), 85-89. Retrieved from http://www.homesciencejournal.com/archives/2016/vol2issue2/PartB/2-1-79.pdf

Prahalad, C. K., \& Ramaswamy, V. (2004). Co creating unique value with customers. Strategy \& Leadership, 32(3), 4-9.

Pratt, S. (2015). What does your gut say? - New Trail. Retrieved from https://www.ualberta.ca/newtrail/featurestories/what-does-your-gut-say

Praveen, K. V. Linking small farmers to market. Markets, Trade and Institutions for Agricultural Development, 1(1.38), 98.Retreived from http://iari.res.in/files/Divisions/CAFT_Training_Manual_2014.pdf\#page=98

Priya, P. S., \& Mathiyalagan, N. (2012). Situational Analysis of the Status of E-Agriculture in Tamil Nadu, India. In E-Agriculture and Rural Development (pp. 118-139). https://doi.org/10.4018/978-1-4666-2655-3.ch011

QCIN. (2017). IndiaGHP Certification Scheme. Retrieved from http://www.qcin.org/PDF/INDGAP/new/IndiaGHP Certification Criteria.pdf

Ramaswamy, N. S. (1998). Rural transport in India. Current Science, 75(8), 800-803.

Ravichamy, P. (2014). Mass media Interventions and Technology transfer among Banana 
Growers : Experiences from Tamil nadu , India. International Journal of Emerging Technologies in Computational and Applied Sciences ( IJETCAS ), 204-209. Retrieved from https://scholar.google.com/scholar?hl=en\&as_sdt=0\%2C5\&q=Mass + media + interventions + and + technology+transfer+among + banana + growers $\% 3 \mathrm{~A}+$ Experiences + from + Tamil + nadu $\%$ $2 \mathrm{C}+$ India\&btnG $=$

Ray, S., \& Lakshmana, K. (2017). IT layoffs: Amid fears of job losses, FITE takes up the fight | business-news | Hindustan Times. Retrieved from http://www.hindustantimes.com/business-news/it-layoffs-amid-fears-of-job-losses-fitetakes-up-the-fight/story-mQOrqo7jXQ8rGjCUzCkuFO.html

Ray, S. S. (2016). Remote Sensing for Agricultural Applications. Retrieved from http://geosmartindia.net/presentations/uses-of-satellite-remote-sensing-and-gis-applicationsin-agriculture-Mahalanobis-NCFC.pdf

Reddi, S. G. D. N. L., Kumar, R. N., Balakrishna, N., \& Rao, V. S. (2015). Microbiological quality of street vended fruit juices in Hyderabad, India and their association between food safety knowledge and practices of fruit juice vendors. International Journal of Current Microbiology and Applied Sciences, 4(1), 970-982.

Regattieri, A., Gamberi, M., \& Manzini, R. (2007). Traceability of food products: General framework and experimental evidence. Journal of Food Engineering, 81(2), 347-356. https://doi.org/10.1016/j.jfoodeng.2006.10.032

Ren, X., Fu, Z., Mu, W., Chinese, X. Z.-T. of the, \& 2009, U. (2009). Traceability system for tilapia breeding quality safety information based on Web. Ingentaconnect.com. Retrieved from http://www.ingentaconnect.com/content/tcsae/tcsae/2009/00000025/00000004/art00031

Roy, M., \& Kumar, S. (2012). Foreign Direct Investment in Agricultural Retailing in India. International Conference on Humanities, Economics and Geography (ICHEG'2012) March, (pp. 17-18). Retrieved from http://psrcentre.org/images/extraimages/3. 312120.pdf

Ruiz-Garcia, L., \& Lunadei, L. (2011). The role of RFID in agriculture: Applications, limitations and challenges. Computers and Electronics in Agriculture, 79(1), 42-50. https://doi.org/10.1016/j.compag.2011.08.010

Ruiz-Garcia, L., Lunadei, L., Barreiro, P., \& Robla, I. (2009). A Review of Wireless Sensor Technologies and Applications in Agriculture and Food Industry: State of the Art and Current Trends. Sensors, 9(6), 4728-4750. https://doi.org/10.3390/s90604728

sadare, sachin. (2016). IoT For Indian Agriculture. Retrieved from http://sachinsadare.in/iot-forindian-agriculture/

Sekabira, H., Bonabana, J., \& Asingwire, N. (2012). Determinants for adoption of information and communications technology (ICT)-based market information services by smallholder farmers and traders in Mayuge District, Uganda. Journal of Development and Agricultural Economics, 4(14), 404-415. https://doi.org/10.5897/JDAE12.081 
Shah, A., Jain, N., \& Bajpai, S. (2015). India @ Digital Bharat CREATING A \$200 BILLION INTERNET ECONOMY. The Boston Consulting Group, Inc., 44. Retrieved from http://image-src.bcg.com/India-at-Digital-Bharat-Jan-2015_tcm21-28779.pdf

Shah, M. (2007). E-Governance in India : Dream or reality? International Journal of Education and Development Using Information and Communication Technology, 3(2), 125-137. Retrieved from http://ijedict.dec.uwi.edu/include/getdoc.php?id=2391\&article=332\&mode=pdf

Sharma, Y. K., Mangla, S. K., Patil, P. P., \& Uniyal, S. (2017). Analyzing Sustainable Food Supply Chain Management Challenges in India. Books.google.com. Retrieved from https://books.google.com/books?hl=en\&lr=\&id=IzdCDwAAQBAJ\&oi=fnd\&pg=PA162\&d $\mathrm{q}=$ Analyzing + Sustainable + Food + Supply + Chain + Management + Challenges + in + India.\&ots $=$ c3jUGGhgfE\&sig=S9HFRxa4Xca8xgVUqMtZuCkKI34

Shiva, V. (2004). The future of food: Countering globalisation and recolonisation of Indian agriculture. Futures, 36(6-7), 715-732. https://doi.org/10.1016/j.futures.2003.12.014

Silander Hagström, T., \& Carlström, C. (2017). IoT in Food Retail : New Technology, New Opportunities. Retrieved from http://www.divaportal.org/smash/record.jsf?pid=diva2\%3A1112858\&dswid=8719

Singh, K. M., Kumar, A., \& Singh, R. K. P. (2015). Role of Information and Communication Technologies in Indian Agriculture: An Overview. SSRN Electronic Journal. https://doi.org/10.2139/ssrn.2570710

Singh, R. B., Kumar, P., \& Woodhead, T. (2002). Smallholder farmers in India: Food security and agricultural policy. Food and Agricultural Organization of the United Nations. Retrieved from http://www.apaari.org/wp-content/uploads/2009/08/small-farmers-inindia1.pdf

Singh, S., Gummagolmath, K. C., \& Sharma, P. (2011). ICT initiatives in Indian agriculture - An overview. Indian Journal of Agricultural Economics, 66(3), 489-497. Retrieved from https://econpapers.repec.org/article/agsinijae/204771.htm

Somashekhar, I., Raju, J., \& Patil, H. (2014). Agriculture Supply Chain Management: A Scenario in India. Retrieved from https://www.researchgate.net/profile/Somashekhar_I_C/publication/268280558_Agriculture _Supply_Chain_Management_A_Scenario_in_India/links/5883189192851c21ff4322f6/Agr iculture-Supply-Chain-Management-A-Scenario-in-India.pdf

Souza-Monteiro, D. M., \& Hooker, N. H. (2013). Food safety and traceability. In US Programs Affecting Food and Agricultural Marketing (pp. 249-271). New York, NY: Springer New York. https://doi.org/10.1007/978-1-4614-4930-0_10

Spink, J., \& Moyer, D. C. (2011). Defining the Public Health Threat of Food Fraud. Journal of Food Science, 76(9). https://doi.org/10.1111/j.1750-3841.2011.02417.x

Sterling, B., Gooch, M., Dent, B., Marenick, N., Miller, A., \& Sylvia, G. (2015). Assessing the value and role of seafood traceability from an entire value-chain perspective. 
Comprehensive Reviews in Food Science and Food Safety, 14(3), 205-268.

https://doi.org/10.1111/1541-4337.12130

Syiem, R., \& Raj, S. (2015). Access and Usage of ICTs for Agriculture and Rural Development by the tribal farmers in Meghalaya State of North-East India. Journal of Agricultural Informatics, 6(3), 2061-862. https://doi.org/10.17700/jai.2015.6.3.190

Sylvester, G. (2015). Success Stories on Information and Communication Technologies for Agriculture and. Retrieved from http://www.fao.org/3/a-i4622e.pdf

TechSci Research. (2015). India Cloud Computing Market Forecast And Opportunities, 2020. Retrieved from https://www.giiresearch.com/report/tsci325299-india-cloud-computingmarket-forecast.html

Thakur, M., \& Hurburgh, C. R. (2009). Framework for implementing traceability system in the bulk grain supply chain. Journal of Food Engineering, 95(4), 617-626. https://doi.org/10.1016/j.jfoodeng.2009.06.028

Thakur, M., Sørensen, C. F., Bjørnson, F. O., Forås, E., \& Hurburgh, C. R. (2011). Managing food traceability information using EPCIS framework. Journal of Food Engineering, 103(4), 417-433. https://doi.org/10.1016/j.jfoodeng.2010.11.012

Thapa, G., \& Gaiha, R. (2014). Smallholder farming in Asia and the Pacific: challenges and opportunities. In New Directions for Smallholder Agriculture (pp. 69-114). https://doi.org/10.1093/acprof:oso/9780199689347.003.0004

The World Bank. India: Issues and Priorities for Agriculture, The World Bank § (2012). Retrieved from http://www.worldbank.org/en/news/feature/2012/05/17/india-agricultureissues-priorities

TheHindu. (2015, October 5). ISRO develops hailstorm app to assess crop damage - The Hindu. Retrieved from http://www.thehindu.com/news/national/isro-develops-hailstorm-app-toassess-crop-damage/article7726309.ece

TheHindu. (2016, February 10). Only 1 out of 15 food businesses registered with FSSAI - The Hindu. Retrieved from http://www.thehindu.com/business/Industry/fssai-on-food-businessregistration/article8219138.ece

TheIndianExpress. (2016). Mobile Internet users in India to reach $371 \mathrm{mn}$ by June 2016 | The Indian Express. Retrieved from http://indianexpress.com/article/technology/tech-newstechnology/mobile-internet-users-in-india-to-reach-371-mn-by-june-2016/

TNN. (2017). The A-Z of tetra paks - Times of India. Retrieved from https://imesofindia.indiatimes.com/life-style/health-fitness/diet/The-A-Z-of-tetrapaks/articleshow/45165737.cms

Unnevehr, L. (2015). Food safety in developing countries: Moving beyond exports. Global Food Security, 4, 24-29. https://doi.org/10.1016/j.gfs.2014.12.001

Vigneswara Ilavarasan, P., \& Srinivasan, N. (2014). National Optical Fibre Network of India A Position Paper. Retrieved from http://broadbandasia.info/wp- 
content/uploads/2014/04/NOFN-India_11-April.pdf

WHO. (2007). WHO ESTIMATES OF THE GLOBAL BURDEN OF FOODBORNE DISEASES. Retrieved from http://apps.who.int/iris/bitstream/10665/199350/1/9789241565165_eng.pdf

WHO. (2015). WHO estimates of the global burden of foodborne diseases.

Wims, P. (2011). ICTs in irish agriculture: Can ICTs improve communication between agribusiness and farmers? In CEUR Workshop Proceedings (Vol. 1152, pp. 103-119).

worldfoodindiA. (2017). Food Processing Sector in India | FDI in Food | Food Value Chain | Advantage of India's Food Sector. Retrieved from https://www.worldfoodindia.in/whyindia

Yadav, I. C., Devi, N. L., Syed, J. H., Cheng, Z., Li, J., Zhang, G., \& Jones, K. C. (2015). Current status of persistent organic pesticides residues in air, water, and soil, and their possible effect on neighboring countries: A comprehensive review of India. Science of the Total Environment, 511, 123-137. https://doi.org/10.1016/j.scitotenv.2014.12.041

Yes Bank. (2016). Confederation of Indian Industry Make in India Opportunities in Food Processing Sector. Retrieved from https://www.yesbank.in/pdf/make_in_india_opportunities_in_food_processing_sector.pdf

Yeung, L. A. (2011). Food safety regulatory framework in selected places. Retrieved from http://www.legco.gov.hk/yr10-11/english/sec/library/1011rp03-e.pdf

Zhang, Y., Wang, L., \& Duan, Y. (2016). Agricultural information dissemination using ICTs: A review and analysis of information dissemination models in China. Information Processing in Agriculture. https://doi.org/10.1016/j.inpa.2015.11.002 


\section{Appendices}

\section{Appendix A}

Selected ICT tools for analyzing adoption level in smallholder farmer, trader and seller in Jalgaon

District, India

\begin{tabular}{|l|l|l|}
\hline \multicolumn{1}{|c|}{ Basic } & \multicolumn{1}{|c|}{ Medium } & \multicolumn{1}{c|}{ Advanced } \\
\hline Newspaper / Magazine & Mobile Phone (Smartphone) & $\begin{array}{l}\text { Rainfall Recording and } \\
\text { Analysis }\end{array}$ \\
\hline Radio & Shetkari Masik Android App & Cropwatch \\
\hline Television & $\begin{array}{l}\text { Social Media (Twitter / Whats } \\
\text { App / Facebook ) }\end{array}$ & Cropsap \\
\hline Mobile Phone (Simple) & $\begin{array}{l}\text { Social Computing / Internet } \\
\text { Access }\end{array}$ & Barcode (Gs1 India) \\
\hline $\begin{array}{l}\text { Text Message SMS / Maha } \\
\text { Krushi SMS }\end{array}$ & $\begin{array}{l}\text { RFID Tag } \\
\text { Kisan SMS Service / Kisan }\end{array}$ & \\
\hline
\end{tabular}

Source: Maha Agri (2016) 
PhD Thesis

Keshav Prakash Dandage

\section{Appendix B}

Screening Questions Set I for Smallholder Banana Farmers in Jalgaon District, India

\begin{tabular}{|c|c|c|c|c|c|c|}
\hline $\mathbf{S} /$ & Question Set I & $\begin{array}{l}\text { Strongly } \\
\text { Agree } \\
\text { (1) }\end{array}$ & $\begin{array}{l}\text { Agree } \\
\text { (2) }\end{array}$ & $\begin{array}{c}\text { Undecided } \\
\text { (3) }\end{array}$ & $\begin{array}{c}\text { Disagree } \\
\text { (4) }\end{array}$ & $\begin{array}{l}\text { Strongly } \\
\text { disagree } \\
\text { (5) }\end{array}$ \\
\hline 1. & $\begin{array}{l}\text { Frequently use of selected tool } \\
\text { and getting useful information } \\
\text { from that tool? }\end{array}$ & & & & & \\
\hline 2. & Tool is very easy to use & & & & & \\
\hline 3. & $\begin{array}{l}\text { Comfortable using in your } \\
\text { own language rather than } \\
\text { English? }\end{array}$ & & & & & \\
\hline 4. & $\begin{array}{l}\text { An easy access to learning the } \\
\text { technique? }\end{array}$ & & & & & \\
\hline 5. & $\begin{array}{l}\text { An information provided by } \\
\text { tool is very helpful }\end{array}$ & & & & & \\
\hline 6. & $\begin{array}{l}\text { After using the system, do you } \\
\text { feel it can be really useful to } \\
\text { increase production and } \\
\text { supply chain? }\end{array}$ & & & & & \\
\hline
\end{tabular}


PhD Thesis

Keshav Prakash Dandage

Appendices

\section{Appendix C}

Screening Questions Set II for Banana Traders and Sellers in Jalgaon District, India

\begin{tabular}{|c|c|c|c|c|c|c|}
\hline $\mathrm{S} / \mathrm{N}$ & Question Set II & $\begin{array}{l}\text { Strongly } \\
\text { Agree } \\
\quad(1)\end{array}$ & $\begin{array}{r}\text { Agree } \\
\text { (2) }\end{array}$ & $\begin{array}{c}\text { Undecided } \\
\text { (3) }\end{array}$ & $\begin{array}{l}\text { Disagre } \\
\mathrm{e} \\
\quad(4)\end{array}$ & $\begin{array}{c}\text { Strongly } \\
\text { disagree } \\
\text { (5) }\end{array}$ \\
\hline 1. & $\begin{array}{l}\text { Frequently use of selected tool } \\
\text { and getting useful information } \\
\text { from that tool? }\end{array}$ & & & & & \\
\hline 2. & Tool is very easy to use & & & & & \\
\hline 3. & $\begin{array}{l}\text { Comfortable using in your own } \\
\text { language rather than English? }\end{array}$ & & & & & \\
\hline 4. & $\begin{array}{l}\text { An easy access to learning the } \\
\text { technique? }\end{array}$ & & & & & \\
\hline 5. & $\begin{array}{l}\text { An information provided by tool } \\
\text { is very helpful }\end{array}$ & & & & & \\
\hline 6. & $\begin{array}{l}\text { Helping in increasing and } \\
\text { controlling over production }\end{array}$ & & & & & \\
\hline 7. & $\begin{array}{l}\text { Helping in increasing business } \\
\text { and trading across market }\end{array}$ & & & & & \\
\hline 8. & $\begin{array}{l}\text { Helpful in controlling over } \\
\text { batches and lots }\end{array}$ & & & & & \\
\hline 9. & $\begin{array}{l}\text { Getting complicated result with } \\
\text { help of this tool }\end{array}$ & & & & & \\
\hline
\end{tabular}


PhD Thesis

Keshav Prakash Dandage

Appendices

\section{Appendix D}

Garrett Ranking Method (Proforma) for smallholder Banana farmer in Jalgaon District, India

Indications 1 st Rank: Strong positive expression, 8 th Rank: Least positive expression

\begin{tabular}{|c|c|c|c|c|c|c|c|c|c|}
\hline Factors & Particulars & 1 & 2 & 3 & 4 & 5 & 6 & 7 & 8 \\
\hline F1 & Poor access of Internet in field & & & & & & & & \\
\hline F2 & Poor Quality of ICT tools & & & & & & & & \\
\hline $\mathbf{F 3}$ & $\begin{array}{l}\text { Lack of Updating of } \\
\text { Technology }\end{array}$ & & & & & & & & \\
\hline F4 & $\begin{array}{l}\text { Lack of Training to farmers } \\
\text { from Agriculture Extension } \\
\text { Officer }\end{array}$ & & & & & & & & \\
\hline F5 & Inadequate electricity supply & & & & & & & & \\
\hline F6 & $\begin{array}{l}\text { Less understanding of English } \\
\text { language, and Education }\end{array}$ & & & & & & & & \\
\hline F7 & $\begin{array}{l}\text { Absence of Government } \\
\text { Policies towards ICT tool for } \\
\text { Smallholder farmer }\end{array}$ & & & & & & & & \\
\hline F8 & High cost of ICT tool & & & & & & & & \\
\hline
\end{tabular}

